Prepared in cooperation with the

New York City Department of Environmental Protection

\title{
Preliminary Assessment of Water Chemistry Related to Groundwater Flooding in Wawarsing, New York, 2009-11
}

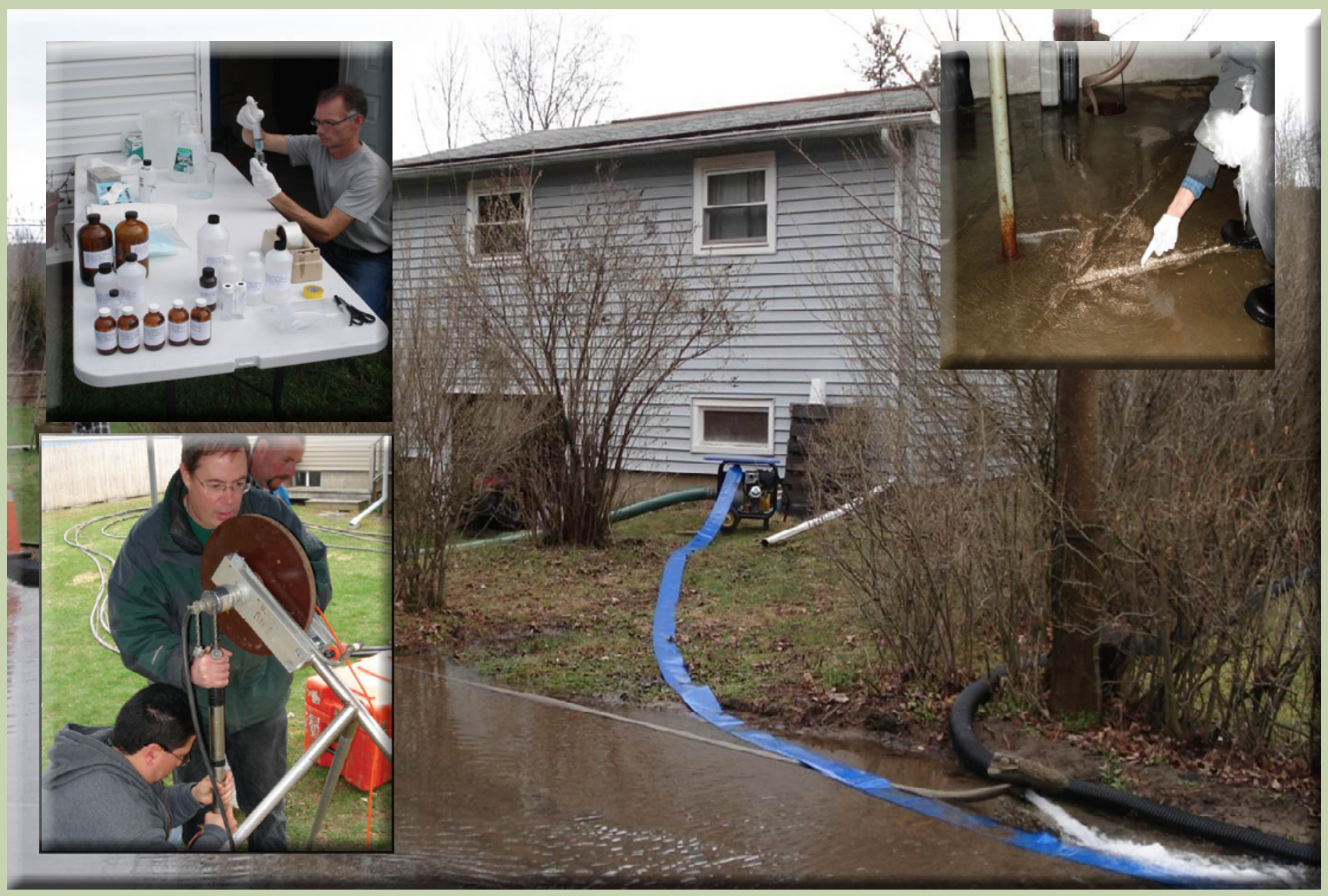

Scientific Investigations Report 2012-5144 


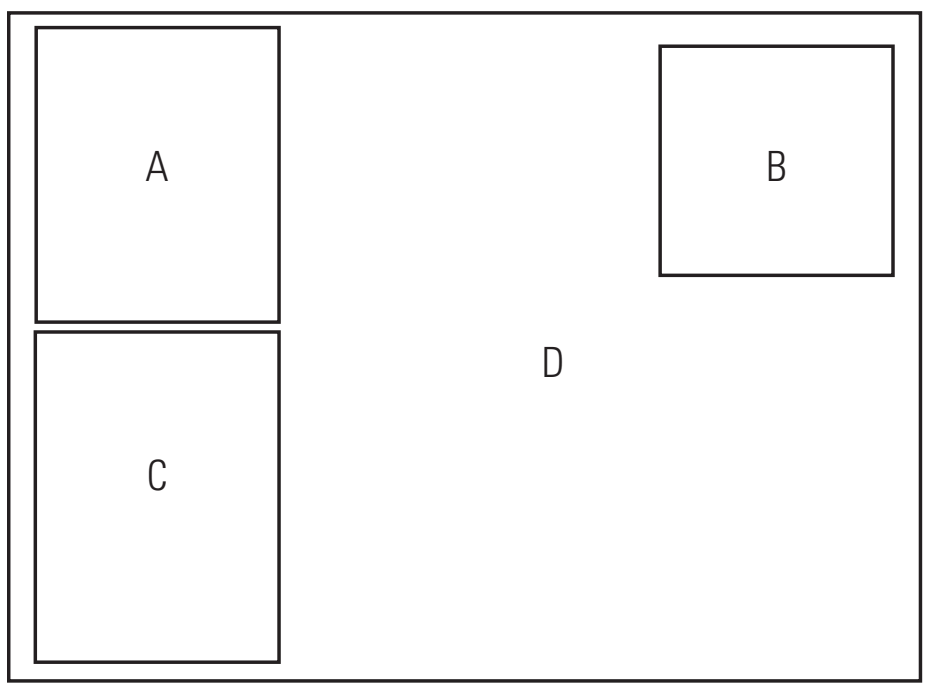

Cover. A, U.S. Geological Survey scientist sampling a domestic well in Wawarsing, New York. B, Basement flooding in Wawarsing, New York. C, U.S. Geological Survey scientists logging a domestic well in Wawarsing, New York. D, Basement pumpage discharging to a flooded street in Wawarsing, New York. 


\section{Preliminary Assessment of Water Chemistry Related to Groundwater Flooding in Wawarsing, New York, 2009-11}

By Craig J. Brown, David A. Eckhardt, Frederick Stumm, and Anthony Chu

Prepared in cooperation with the

New York City Department of Environmental Protection

Scientific Investigations Report 2012-5144 


\title{
U.S. Department of the Interior \\ KEN SALAZAR, Secretary \\ U.S. Geological Survey \\ Marcia K. McNutt, Director
}

\author{
U.S. Geological Survey, Reston, Virginia: 2012
}

For more information on the USGS - the Federal source for science about the Earth, its natural and living resources, natural hazards, and the environment, visit http://www.usgs.gov or call 1-888-ASK-USGS.

For an overview of USGS information products, including maps, imagery, and publications, visit http://www.usgs.gov/pubprod

To order this and other USGS information products, visit http://store.usgs.gov

Any use of trade, firm, or product names is for descriptive purposes only and does not imply endorsement by the U.S. Government.

Although this information product, for the most part, is in the public domain, it also may contain copyrighted materials as noted in the text. Permission to reproduce copyrighted items must be secured from the copyright owner.

Suggested citation:

Brown, C.J., Eckhardt, D.A., Stumm, Frederick, and Chu, Anthony, 2012, Preliminary assessment of water chemistry related to groundwater flooding in Wawarsing, New York, 2009-11: U.S. Geological Survey Scientific Investigations Report 2012-5144, 36 p. (Also available at http://pubs.usgs.gov/sir/2012/5144/.) 


\section{Acknowledgments}

The authors would like to thank Ira Stern and William Richardson of the New York City Department of Environmental Protection, Bureau of the Grahamsville Region, Western Operations Division, for providing data and information and for granting access to the Rondout mixing chamber. In addition, the authors would like to thank the residents of the town of Wawarsing, New York, for allowing access to collect samples from wells and springs on their properties and for providing information related to flooding. Thanks are extended to the town of Wawarsing for granting access to monitoring sites at Lippman Park and to James Rodden, Jr., of the Ulster County Health Department, who provided water-quality data on homeowner wells. Special thanks are extended to Paul Heisig, U.S. Geological Survey New York Water Science Center, for providing technical support and establishing part of the groundwater network. 
THIS PAGE INTENTIONALLY LEFT BLANK 


\section{Contents}

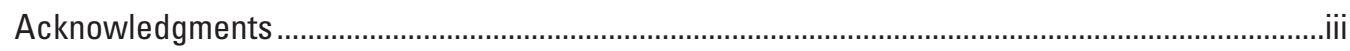

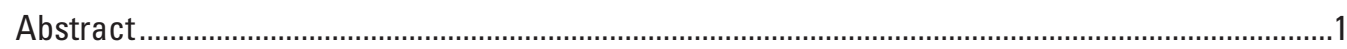

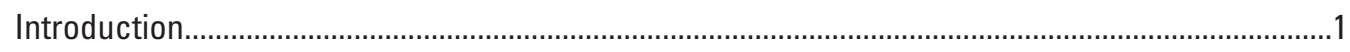

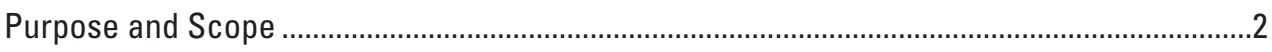

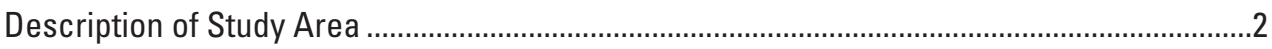

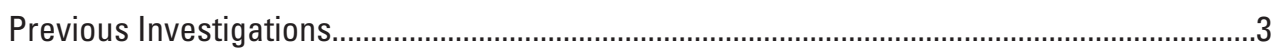

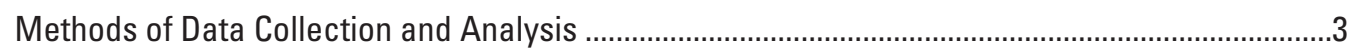

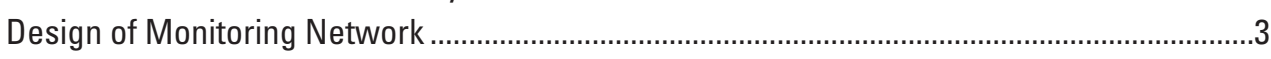

Collection and Analysis of Water Samples .............................................................................

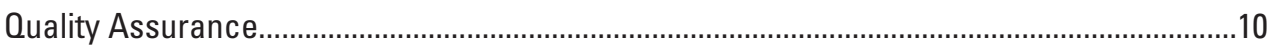

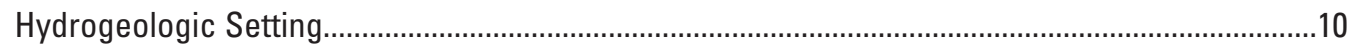

Geology

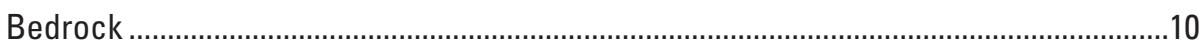

Unconsolidated Deposits .................................................................................................11

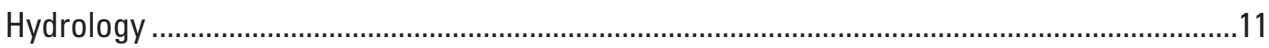

Water-Quality Monitoring Sites......................................................................................11

Rondout Reservoir and the Rondout-West Branch Water Tunnel................................11

Hydrologic Effects of Temporary Rondout-West Branch Water Tunnel Shutdowns.....16

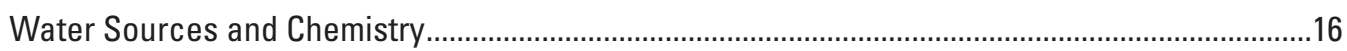

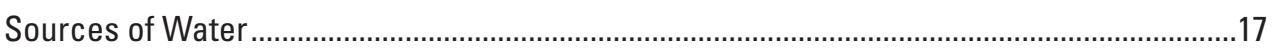

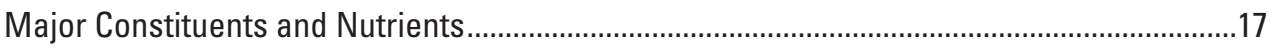

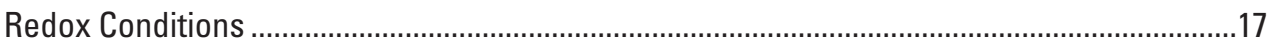

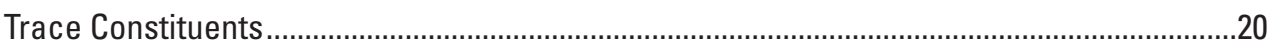

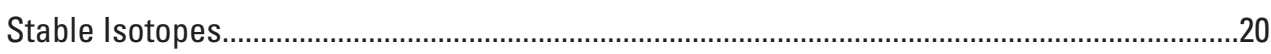

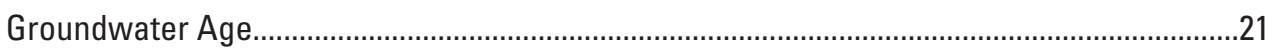

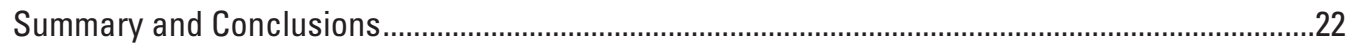

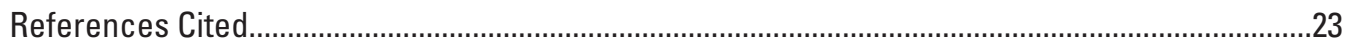




\section{Figures}

1. Map showing Wawarsing study area, including Port Jervis Trough (Kingston to Port Jervis), four reservoirs (Cannonsville, Pepacton, Neversink, and Rondout), Delaware Aqueduct, Roundout Reservoir sampling site 01366400 at the influent to Rondout-West Branch Tunnel, and Kensico Reservoir, in Westchester County, New York

2. Map showing monitoring sites at a lake (Lippman Lake), springs, unconsolidated monitoring and supply wells, and bedrock supply wells in Wawarsing, Ulster County, New York

3. A. Map showing locations of wells and surface-water sites; Rondout-West Branch Tunnel geology; and water-inflow rates documented during tunnel construction in the Wawarsing study area, Ulster County, New York. B. Cross section of geology observed during New York City Board of Water Supply test borings and RondoutWest Branch Tunnel construction from A to $A^{\prime}$ within the study area, Town of Wawarsing, Ulster County, New York

4. Piper diagram showing the percentage of total equivalents of major cations and anions in surface-water and groundwater samples collected from a lake, springs, and wells in Wawarsing and for the Rondout Reservoir at the influent to the RondoutWest Branch Tunnel in Lackawack, Ulster County, New York, 2009-11.

5. Diagram showing saturation indexes for calcite and gypsum in surface-water and groundwater samples collected from a lake, springs, and wells in the study area, Wawarsing, New York, and for the Rondout Reservoir at the influent to the RondoutWest Branch (RWB) Tunnel in Lackawack, Ulster County, New York, 2009-11.

\section{Tables}

1. Data on the sampling-site locations and construction of wells in the Wawarsing study area, and for the Rondout Reservoir at the influent to the Rondout-West

Branch Tunnel in Lackawack, Ulster County, New York, 2009-11.

2. Classes of water-quality chemical characteristics and constituents measured in water samples from a lake, springs, and wells in the Wawarsing study area, and for the Rondout Reservoir at the influent to the Rondout-West Branch Tunnel in Lackawack, Ulster County, New York, 2009-11

3. General chemical characteristics, concentrations of major elements and nutrients, saturation indexes, and percent charge balance error in surface-water and groundwater samples from a lake, springs, and wells in the Wawarsing study area, and for the Rondout Reservoir at the influent to the Rondout-West Branch Tunnel in Lackawack, Ulster County, New York, 2009-11

4. Concentrations of dissolved gases and age tracers, redox properties, and apparent age of surface-water and groundwater samples from a lake, springs, and wells in the Wawarsing study area, and for the Rondout Reservoir at the influent to the Rondout-West Branch Tunnel in Lackawack, Ulster County, New York, 2009-11

5. Dissolved concentrations of trace elements and stable-isotope ratios in surfacewater and groundwater samples from a lake, springs, and wells in the Wawarsing study area, and for the Rondout Reservoir at the influent to the Rondout-West Branch Tunnel in Lackawack, Ulster County, New York, 2009-11 


\section{Conversion Factors, Datum, and Abbreviations}

Inch/Pound to SI

\begin{tabular}{lcl}
\hline \multicolumn{1}{c}{ Multiply } & By & \multicolumn{1}{c}{ To obtain } \\
\hline inch (in.) & Length & \\
inch (in.) & 2.54 & centimeter $(\mathrm{cm})$ \\
foot (ft) & 25.4 & millimeter $(\mathrm{mm})$ \\
mile (mi) & 0.3048 & meter $(\mathrm{m})$ \\
\hline & 1.609 & kilometer $(\mathrm{km})$ \\
\hline square mile $\left(\mathrm{mi}^{2}\right)$ & Area & \\
\hline & 2.590 & square kilometer $\left(\mathrm{km}^{2}\right)$ \\
\hline gallon (gal) & Volume & liter $(\mathrm{L})$ \\
gallon (gal) & 3.785 & cubic meter $\left(\mathrm{m}^{3}\right)$ \\
\hline & 0.003785 & \\
\hline gallon per minute (gal/min) & Flow rate & liter per second $(\mathrm{L} / \mathrm{s})$ \\
gallon per day (gal/d) & 0.06309 & cubic meter per day $\left(\mathrm{m}^{3} / \mathrm{d}\right)$ \\
million gallons per day (Mgal/d) & 0.003785 & cubic meter per second $\left(\mathrm{m}^{3} / \mathrm{s}\right)$ \\
inch per year (in/yr) & 0.04381 & millimeter per year $(\mathrm{mm} / \mathrm{yr})$ \\
\hline
\end{tabular}

Temperature in degrees Celsius $\left({ }^{\circ} \mathrm{C}\right)$ may be converted to degrees Fahrenheit $\left({ }^{\circ} \mathrm{F}\right)$ as follows:

$$
{ }^{\circ} \mathrm{F}=\left(1.8 \times{ }^{\circ} \mathrm{C}\right)+32
$$

Vertical coordinate information is referenced to the North American Vertical Datum of 1988 (NAVD 88) or the National Geodetic Vertical Datum of 1929 (NGVD 29).

Horizontal coordinate information is referenced to the North American Datum of 1983 (NAD 83).

Altitude, as used in this report, refers to distance above the vertical datum.

Specific conductance is given in microsiemens per centimeter at 25 degrees Celsius $(\mu \mathrm{S} / \mathrm{cm}$ at $\left.25^{\circ} \mathrm{C}\right)$.

Concentrations of chemical constituents in water are given either in parts per trillion by volume (pptv), milligrams per liter (mg/L), picograms per liter (pg/L), molarity, or moles per liter (mol/L), milligrams per kilogram $(\mathrm{mg} / \mathrm{kg})$, picomoles per kilogram $(\mathrm{pmol} / \mathrm{kg})$, or femtomoles per kilogram (femtomol $/ \mathrm{kg}$ ), cubic centimeters per liter at standard temperature and pressure $\left(\mathrm{cm}^{3} \mathrm{STP} / \mathrm{L}\right)$, or picoCuries per liter ( $\mathrm{pCi} / \mathrm{L})$. 


\section{Abbreviations}

\begin{tabular}{|c|c|}
\hline$>$ & greater than \\
\hline$<$ & less than \\
\hline$\delta$ & delta \\
\hline$E$ & estimated concentration \\
\hline IAP/Ksp & ratio of ion activity product to solubility product coefficient \\
\hline MCL & maximum contaminant levels \\
\hline MRL & minimum reporting level \\
\hline MVT & Mississippi Valley Type \\
\hline MWL & meteoric water line \\
\hline NAWOA & National Water Quality Assessment Program \\
\hline NOAA & National Oceanic and Atmospheric Administration \\
\hline NWOL & National Water Quality Laboratory \\
\hline NWS & National Weather Service \\
\hline NYC & New York City \\
\hline NYCDEP & New York City Department of Environmental Protection \\
\hline RWB & Rondout-West Branch \\
\hline TEAP & terminal electron-accepting processes \\
\hline USGS & U.S. Geological Survey \\
\hline VCDT & Vienna Canyon Diablo Troilite \\
\hline VOC & volatile organic compound \\
\hline VPDB & Vienna Pee Dee Belemnite \\
\hline VSMOW & Vienna Standard Mean Ocean Water \\
\hline $\mathrm{Ag}$ & silver \\
\hline $\operatorname{Ar}$ & argon \\
\hline As & arsenic \\
\hline B & boron \\
\hline $\mathrm{Ba}$ & barium \\
\hline $\mathrm{Be}$ & beryllium \\
\hline $\mathrm{Br}$ & bromide \\
\hline $\mathrm{Ca}$ & calcium \\
\hline $\mathrm{Cd}$ & cadmium \\
\hline $\mathrm{CH}_{4}$ & methane \\
\hline CFCs & chlorofluorocarbons \\
\hline Co & cobalt \\
\hline $\mathrm{CO}_{2}$ & carbon dioxide \\
\hline $\mathrm{Cr}$ & chromium \\
\hline $\mathrm{Cu}$ & copper \\
\hline DIC & dissolved inorganic carbon \\
\hline
\end{tabular}




\begin{tabular}{|c|c|}
\hline DO & dissolved oxygen \\
\hline E. coli & Escherichia coli \\
\hline $\mathrm{F}^{-}$ & fluoride \\
\hline $\mathrm{Fe}$ & iron \\
\hline $\mathrm{H}$ & hydrogen \\
\hline${ }^{2} \mathrm{H}$ & deuterium \\
\hline${ }^{3} \mathrm{H}$ & tritium \\
\hline $\mathrm{H}_{2} \mathrm{~S}, \mathrm{HS}^{-}$ & hydrogen sulfide species \\
\hline $\mathrm{He}$ & helium \\
\hline $\mathrm{HNO}_{3}$ & nitric acid \\
\hline $\mathrm{K}$ & potassium \\
\hline $\mathrm{Li}$ & lithium \\
\hline $\mathrm{Mb}$ & molybdenum \\
\hline $\mathrm{Mg}$ & magnesium \\
\hline $\mathrm{Mn}$ & manganese \\
\hline $\mathrm{N}, \mathrm{N}_{2}$ & nitrogen \\
\hline $\mathrm{Na}$ & sodium \\
\hline $\mathrm{NH}_{4}^{+}$ & ammonium \\
\hline $\mathrm{Ni}$ & nickel \\
\hline $\mathrm{NO}_{2}^{-}$ & nitrite \\
\hline $\mathrm{NO}_{3}^{-}$ & nitrate \\
\hline $\mathrm{O}_{2}$ & oxygen \\
\hline$P$ & phosphorus \\
\hline $\mathrm{Pb}$ & lead \\
\hline $\mathrm{PO}_{4}^{2-}$ & phosphate \\
\hline S & sulfur \\
\hline Se & selenium \\
\hline $\mathrm{SF}_{6}$ & sulfur hexafluoride \\
\hline $\mathrm{SO}_{4}^{2}-$ & sulfate \\
\hline $\mathrm{SiO}_{2}$ & silica \\
\hline $\mathrm{Sr}$ & strontium \\
\hline $\mathrm{TI}$ & thallium \\
\hline $\mathrm{U}$ & uranium \\
\hline V & vanadium \\
\hline $\mathrm{Zn}$ & zinc \\
\hline
\end{tabular}


THIS PAGE INTENTIONALLY LEFT BLANK 


\title{
Preliminary Assessment of Water Chemistry Related to Ground water Flooding in Wawarsing, New York, 2009-11
}

\author{
By Craig J. Brown, David A. Eckhardt, Frederick Stumm, and Anthony Chu
}

\section{Abstract}

Water-quality samples collected in an area prone to groundwater flooding in Wawarsing, New York, were analyzed and assessed to better understand the hydrologic system and to aid in the assessment of contributing water sources. Above average rainfall over the past decade, and the presence of a pressurized water tunnel that passes about 700 feet beneath Wawarsing, could both contribute to groundwater flooding. Water samples were collected from surface-water bodies, springs, and wells and analyzed for major and trace inorganic constituents, dissolved gases, age tracers, and stable isotopes. Distinct differences in chemistry exist between tunnel water and groundwater in unconsolidated deposits and in bedrock, and among groundwater samples collected from some bedrock wells during high head pressure and low head pressure of the Rondout-West Branch Tunnel. Samples from bedrock wells generally had relatively higher concentrations of sulfate $\left(\mathrm{SO}_{4}{ }^{2-}\right)$, strontium $(\mathrm{Sr})$, barium $(\mathrm{Ba})$, and lower concentrations of calcium $(\mathrm{Ca})$ and bicarbonate $\left(\mathrm{HCO}_{3}^{-}\right)$, as compared to unconsolidated wells. Differences in stable-isotope ratios among oxygen-18 to oxygen-16 $\left(\delta^{18} \mathrm{O}\right)$, hydrogen- 2 to hydrogen-1 $\left(\delta^{2} \mathrm{H}\right)$, sulfur-34 to sulfur-32 $\left(\delta^{34} \mathrm{~S}\right)$ of $\mathrm{SO}_{4}{ }^{2-}, \mathrm{Sr}-87$ to $\mathrm{Sr}-86\left({ }^{87} \mathrm{Sr} /{ }^{86} \mathrm{Sr}\right)$, and $\mathrm{C}-13$ to $\mathrm{C}-12\left(\delta^{13} \mathrm{C}\right)$ of dissolved inorganic carbon (DIC) indicate a potential for distinguishing water in the Delaware-West Branch Tunnel from native groundwater. For example, ${ }^{87} \mathrm{Sr} /{ }^{86} \mathrm{Sr}$ ratios were more depleted in groundwater samples from most bedrock wells, as compared to samples from surface-water sources, springs, and wells screened in unconsolidated deposits in the study area.

Age-tracer data provided useful information on pathways of the groundwater-flow system, but were limited by inherent problems with dissolved gases in bedrock wells. The sulfur hexafluoride $\left(\mathrm{SF}_{6}\right)$ and (or) chlorofluorocarbons (CFCs) apparent recharge years of most water samples from wells screened in unconsolidated deposits and springs ranged from 2003 to 2010 (current) and indicate short flow paths from the point of groundwater recharge. All but three of the samples from bedrock wells had interference problems with dissolved gases, mainly caused by excess air from degassing of hydrogen sulfide and methane. The $\mathrm{SF}_{6}$ and (or) CFC apparent recharge years of samples from three of the bedrock wells ranged from the 1940 s to the early 2000 s; the sample with the early 2000s recharge year was from a flowing artesian well that was chemically similar to water samples collected at the influent to the tunnel at Rondout Reservoir and the most hydraulically responsive to water tunnel pressure compared to other bedrock wells.

Data described in this report can be used, together with hydrogeologic data, to improve the understanding of source waters and groundwater-flow patterns and pathways, and to help assess the mixing of different source waters in water samples. Differences in stable isotope ratios, major and trace constituent concentrations, saturation indexes, tritium concentrations, and apparent groundwater ages will be used to estimate the proportion of water that originates from RondoutWest Branch Tunnel leakage.

\section{Introduction}

Groundwater flooding of streets and residential basements during fall 2008 in the Rondout Valley near the town of Wawarsing, Ulster County, New York, prompted the New York City Department of Environmental Protection (NYCDEP) to ask the U.S. Geological Survey (USGS) to characterize the groundwater-flow system of the area. Precipitation records indicate that above average rainfall over much of the past two decades, particularly over the past decade, has aggravated flooding problems (Stumm and others, 2012). Additionally, a segment of the Rondout-West Branch (RWB) Tunnel, which is an underground concrete-lined structure that passes about 700 feet (ft) beneath Wawarsing and carries pressurized water through from the Catskill Mountains to New York City (NYC), is leaking and also could be contributing to groundwater flooding (Stumm and others, 2012). This 44-mile (mi) long, 13.5-ft diameter water tunnel between the Rondout Reservoir and the Catskill Aqueduct carries about one-half of the NYC water supply and has a capacity of about 1.03 billion gallons per day (gal/d) (New York City Department of Environmental Protection, 2010). One of the two primary areas of leakage along the RWB Tunnel is beneath Wawarsing; during construction of the RWB Tunnel, this section of bedrock beneath the Rondout Valley was observed to be highly faulted and 
weathered, had over 9,000 gallons per minute ( $\mathrm{gal} / \mathrm{min})$ of inflow, and required over 20,000 bags of concrete and steel reinforcements to stabilize the bedrock. The total estimated leakage out of the RWB Tunnel is 15 to 35 million gallons per day (Mgal/d) (James Canale, New York City Department of Environmental Protection, written commun., 2011; DiNapoli, 2007). In 2003 and 2009, an autonomous underwater vehicle was used to inspect the interior of the RWB Tunnel and recorded 8,200 linear feet of cracking throughout the tunnel

(James Canale, New York City Department of Environmental Protection, written commun., 2011). Most of the cracking was observed in the sections of the tunnel that are within the limestone units underlying Roseton and Wawarsing, N.Y.

Water-chemistry data were interpreted with hydrogeologic data, which are detailed in a companion report (Stumm and others, 2012), to help identify and distinguish between water sources that may contribute to the groundwater flooding observed in Wawarsing. Inorganic constituents, stable isotopes, and age tracers in groundwater and springs are useful indicators of different sources of water, including surface water or anthropogenic sources, as well as geochemical processes in different parts of the aquifer system. Waterchemistry data were interpreted with hydrogeologic data, which are detailed in a companion report (Stumm and others, 2012), to help identify and distinguish between water sources that may contribute to the groundwater flooding observed in Wawarsing.

In 2008, the USGS was tasked by the NYCDEP to characterize the hydrogeologic conditions in the Wawarsing area and investigate the possible relation between groundwater flooding and leakage from the adjacent RWB Tunnel. A companion report (Stumm and others, 2012) describes the hydrology of the Wawarsing study area. Together, the reports serve as a foundation for understanding the hydrologic system and how it is affected by precipitation and pressurized water leaking from the RWB Tunnel.

\section{Purpose and Scope}

The purposes of this report are to describe the collection and analysis of water samples and to present some general interpretation of water-chemistry data in order to better understand the hydrologic system and to aid in the assessment of sources of groundwater flooding in the town of Wawarsing, N.Y. The report presents information on the hydrogeologic setting, the occurrence and distribution of chemical constituents and characteristics, and groundwaterage estimates for groundwater samples in the study area. Hydrogeologic data from a companion report (Stumm and others, 2012) are used in this analysis. The report presented herein describes general water-chemistry characteristics, such as oxidation-reduction (redox) conditions, $\mathrm{pH}$, and water types at the Rondout Reservoir inflow to the RWB Tunnel, Lippman Lake, 4 springs, and 19 wells, including 9 wells screened in unconsolidated deposits and 10 wells completed in bedrock. A description of the design of the monitoring network and methods of data collection and analysis of water-level fluctuations are included. The interpretive steps for estimating groundwater ages using atmospheric tracers are described, along with the distribution of the interpreted groundwater ages in selected wells.

The level of interpretation in this report is limited because additional information is required for a detailed assessment. Information on the geology, hydrogeology, and additional water-quality sample analysis in the study area is required to assess the sources of water in the aquifer system related to flooding.

\section{Description of Study Area}

The study area encompasses a 12-square mile $\left(\mathrm{mi}^{2}\right)$ area in Wawarsing, N.Y., that is prone to frequent groundwater flooding. A sampling site at Rondout Reservoir at Lackawack (station 01366400; fig. 1), where reservoir water enters the RWB Tunnel portion of the Delaware Aqueduct was used to represent water from the RWB Tunnel. The Rondout Valley near the town of Wawarsing, Ulster County, N.Y., is part of the Port Jervis Trough, which is a deep, glaciated valley that extends about 100 mi southwestward from Kingston through Kerhonkson, N.Y., and continues into Pennsylvania. The Port Jervis Trough separates the Shawangunk Mountains to the east from the Catskill Front (eastern side of the Catskill Mountains) to the west (Reynolds, 2007). The valley in the study area is underlain by gravel, sand, silt, and clay of Pleistocene and Holocene age (Cadwell and others, 1989) and bedrock sequences of limestone, sandstone, and shale with substantial fracturing and faulting (Dibbell, 1944).

The population of Wawarsing was 13,157, according to the 2010 U.S. Census (U.S. Census Bureau, 2010), and land use is predominantly residential. Wawarsing lies to the west of the Shawangunk Mountains, which are the north-easternmost expression of the Valley and Ridge province of the central Appalachians. Land-surface altitudes range from about $270 \mathrm{ft}$ in the flood-prone area in Wawarsing to about $730 \mathrm{ft}$ at the "mixing chamber" from the Rondout Reservoir to the Delaware Aqueduct (in this report, altitudes are referenced to the North American Vertical Datum of 1988, unless otherwise specified). The sampling network in Wawarsing and the Delaware Aqueduct water sampled in Lackawack are herein described as the "study area."

The study area is underlain by unconsolidated deposits of variable thickness, including Pleistocene till and stratified drift, and Holocene alluvium. Much of the stratified drift is glacial lake silt and clay, which, along with the till, impedes infiltration and groundwater flow. The surrounding bedrock highlands rise about $150 \mathrm{ft}$ to the west of the valley and about $300 \mathrm{ft}$ to the east. 


\section{Previous Investigations}

Several studies have focused on the NYC water-supply system and, more specifically, the RWB Tunnel. Merguerian (2000) described the history of the NYC water-supply system. Stumm and others (2012) studied the hydrologic effects of temporary shutdowns of the RWB Tunnel on the groundwater-flow system in Wawarsing. A drainage study (Chadd Hodgkinson, Malcolm Pirnie, written commun., 2009) indicated that higher than average rainfall and poor drainage contributed to flooding of streets and basements in the study area.

The surficial and bedrock geology of the study area is described in several published reports. Drilling logs for wells in the study area were compiled by Frimpter (1970), who later characterized the hydrogeologic units in the study area (Frimpter, 1972). Reynolds (2007) mapped the surficial geology of the southern part of the study area and described the major unconsolidated units. Berkey (1911) described the unconsolidated deposits, bedrock geology, and possible faults within the Rondout Valley. Dibbell (1944) compiled the construction, geology, and hydrology of the RWB Tunnel within the study area. Fluhr $(1950,1953)$ described the results of exploration drilling by the NYCDEP in the study area.

\section{Methods of Data Collection and Analysis}

The design of the sampling network of surface water, springs, monitoring wells, and supply wells; the water-quality sampling and analyses; age dating of groundwater; methods of quality assurance; and data interpretation are described in this section.

\section{Design of Monitoring Network}

The monitoring network includes sites for water-level measurements and water-quality sampling. The water-level monitoring network is discussed in detail by Stumm and others (2012) (fig. 2, table 1); water levels were measured at 31 sites to help determine the potentiometric surface and direction of groundwater flow (Stumm and others, 2012). Most of the wells in the monitoring network are used for private or public water supply, but monitoring wells were specifically drilled in the unconsolidated deposits during 2009-10 to monitor water levels and for potential water-quality sampling (Stumm and others, 2012).

Water-quality monitoring includes surface-water sites (Rondout Reservoir, Lippman Lake), supply and monitoring wells, and springs (table 1, figs. 1 and 2). The springs include two basement sites associated with flooding (U1665 and U1666), in addition to other springs (U1667, U1668) or well points installed at springs or "spring wells" (U1632 and
U1633) in the hills to the east. The sampled wells include both monitoring and domestic and public supply wells in the unconsolidated aquifer and domestic and public supply wells in fractured bedrock.

\section{Collection and Analysis of Water Samples}

Water-quality samples were collected during conditions in which (1) basements were flooding in the Wawarsing areas and the water tunnel was under typical high-pressure conditions, (2) basements were not flooding and the water tunnel was under typical high-pressure conditions, and (3) basements were not flooding and the water tunnel was depressurized for repair work. Sites were sampled for an extensive list of constituents, including major ions and trace elements, dissolved gases, age tracers, and stable isotopes (tables 2-5). Surface-water bodies generally were not analyzed for dissolved gases, chlorofluorocarbons (CFCs), or sulfur hexafluoride $\left(\mathrm{SF}_{6}\right)$, which were used to estimate groundwater age, because they are sensitive to atmospheric interaction; however, these constituents were analyzed in some cases to provide source end members for mixing. Field characteristics, which include water temperature, $\mathrm{pH}$, and specific conductance, were measured during sample collection in accordance with USGS procedures described by Koterba and others (1995).

Water was sampled according to protocols by Koterba and others (1995). Wells were purged, and field measurements of temperature, specific conductance, $\mathrm{pH}$, turbidity, and dissolved oxygen (DO) concentrations were monitored until stable. Concentrations of total dissolved sulfides $\left(\mathrm{H}_{2} \mathrm{~S}\right.$ plus HS', herein referred to as " $\mathrm{H}_{2} \mathrm{~S}$ ") and low concentrations of DO (less than 1 milligram per liter $(\mathrm{mg} / \mathrm{L})$ ) were measured onsite using colorimetric procedures (HACH Company, 2002). Water samples collected for analyses of major ions, trace elements, nutrients, and stable isotope ratios for ${ }^{87} \mathrm{Sr} /{ }^{86} \mathrm{Sr}, \delta^{34} \mathrm{~S}$ of $\mathrm{SO}_{4}{ }^{2-}$, and $\delta^{13} \mathrm{C}$ of dissolved inorganic carbon (DIC) were filtered with a 0.45 -micrometer $(\mu \mathrm{m})$ inline filter. For water with low concentrations of $\mathrm{SO}_{4}^{2-}$, samples were collected on an anion-exchange resin column (Carmody and others, 1998). Water samples for $\delta^{13} \mathrm{C}$ of DIC analysis were collected in 40 milliliter $(\mathrm{mL})$ glass vials, which were preserved with 5 to 10 milligrams (mg) of copper sulfate and sealed with a Teflon/ silicon septa cap.

Water samples to be analyzed for dissolved gases were collected in 160-mL septum bottles (sealed in a large beaker under flow of evacuated well water). Dissolved gases $\left(\mathrm{N}_{2}, \mathrm{Ar}\right.$, $\mathrm{CO}_{2}, \mathrm{CH}_{4}$, and $\mathrm{O}_{2}$ ) were analyzed by gas chromatography after extraction from sample headspaces (Busenberg and others, 1998). The resulting data were used to define recharge temperatures for age dating because the solubility of atmospheric tracers varies as a function of temperature and for determining concentrations of excess air. Excess air consists of air trapped in pores that dissolves in groundwater, typically after a rapid rise in the water table. Recharge temperatures were calculated 


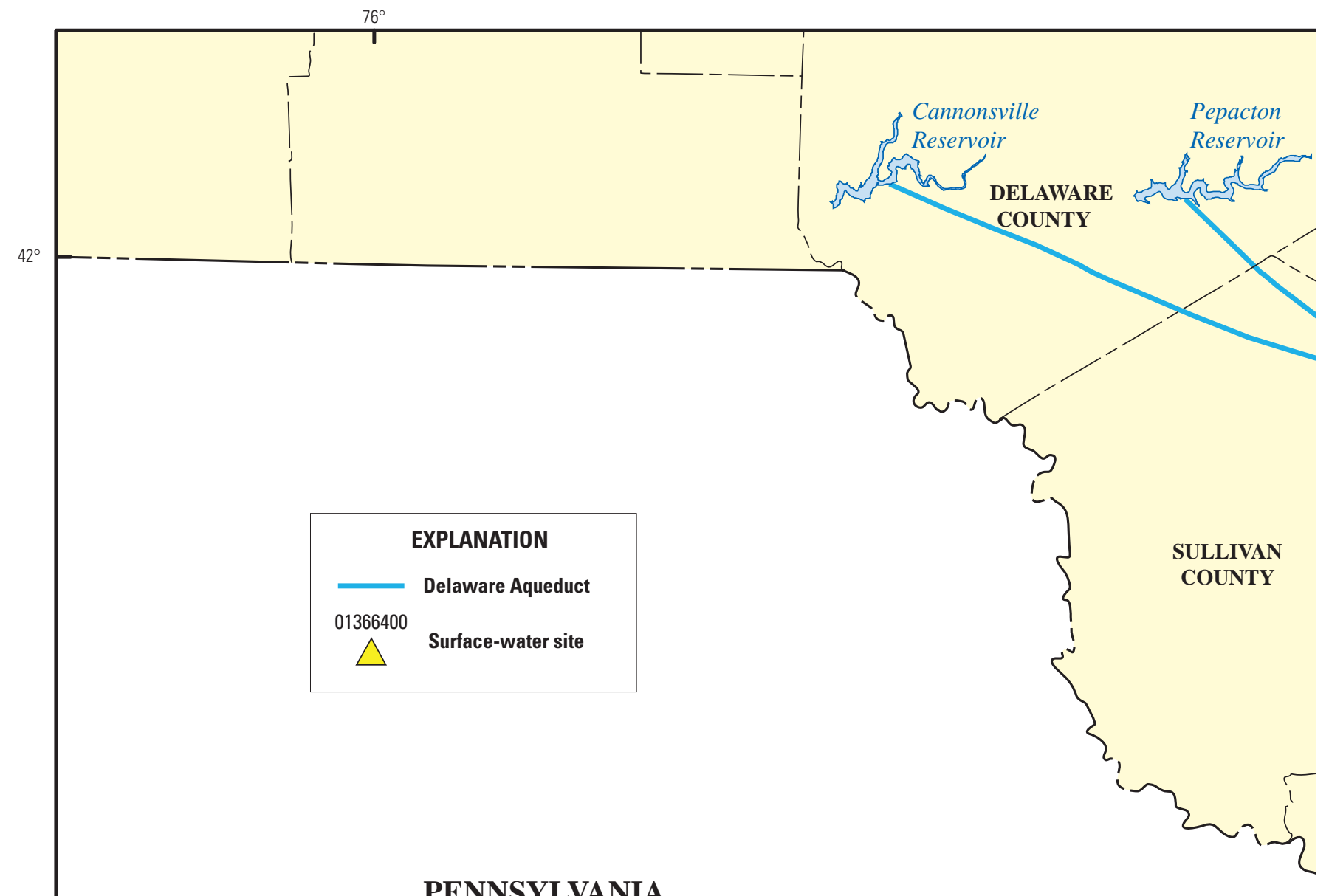

\section{PENNSYLVANIA}

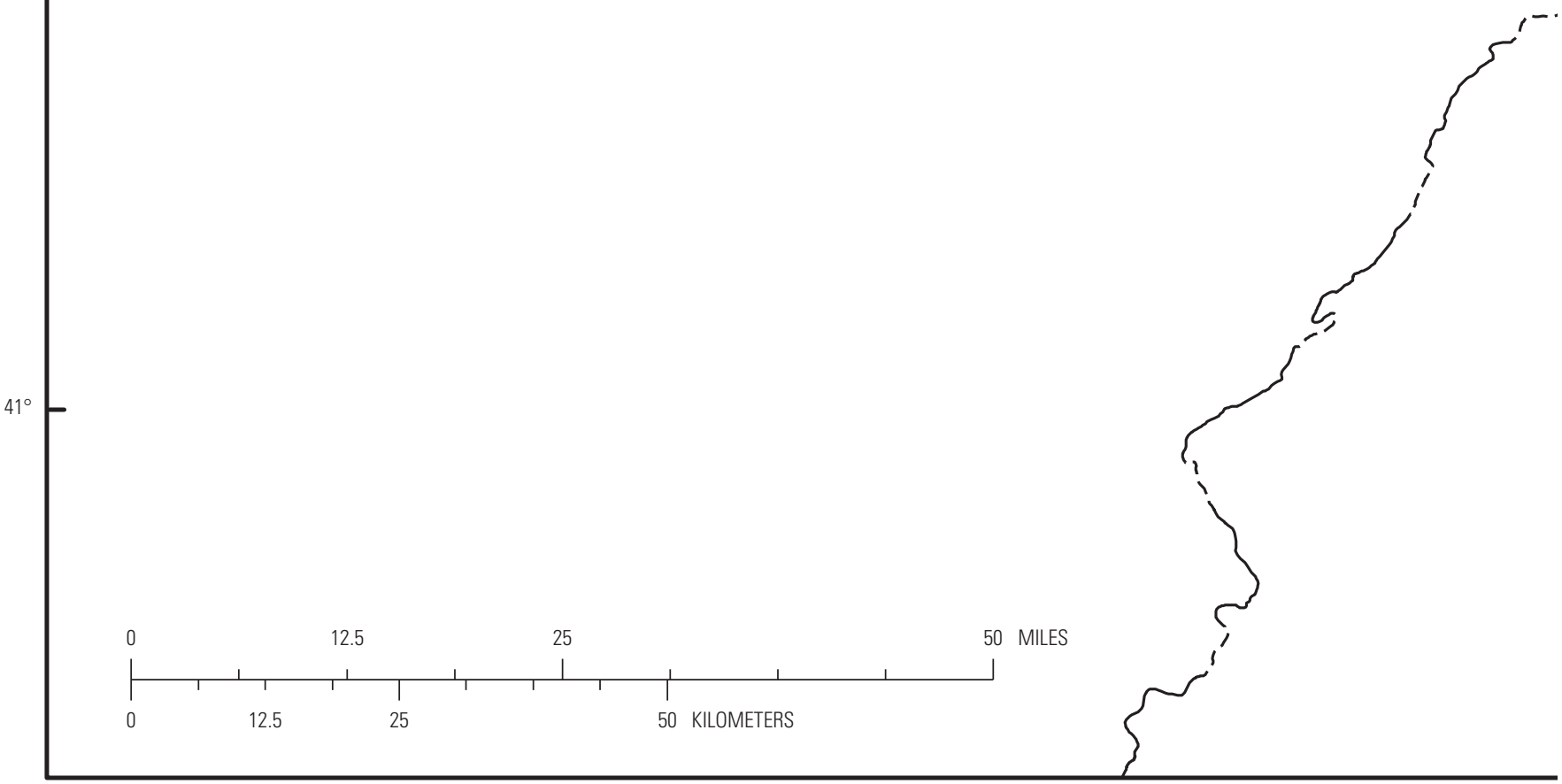

Base from U.S. Geological Survey Digital Data 1:100,000 series Lambert Conformal Conic Projection

North American Datum of 1983

Figure 1. Wawarsing study area, including Port Jervis Trough (Kingston to Port Jervis), four reservoirs (Cannonsville, Pepacton, Neversink, and Rondout), Delaware Aqueduct, Roundout Reservoir sampling site 01366400 at the influent to Rondout-West Branch Tunnel, and Kensico Reservoir, in Westchester County, New York. (Modified from Stumm and others, 2012) 


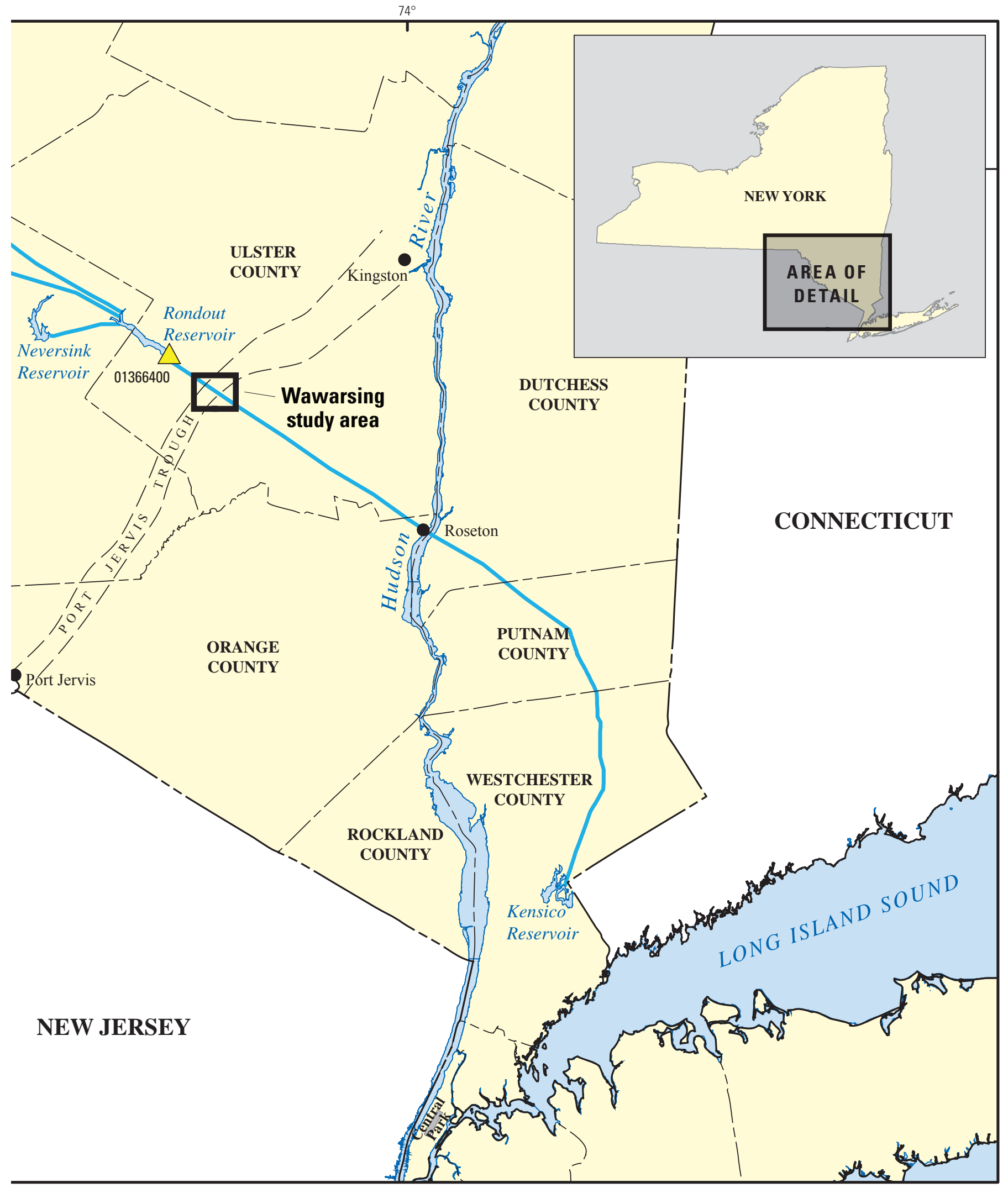

Figure 1. Wawarsing study area, including Port Jervis Trough (Kingston to Port Jervis), four reservoirs (Cannonsville, Pepacton, Neversink, and Rondout), Delaware Aqueduct, Roundout Reservoir sampling site 01366400 at the influent to Rondout-West Branch Tunnel, and Kensico Reservoir, in Westchester County, New York. (Modified from Stumm and others, 2012)—Continued 


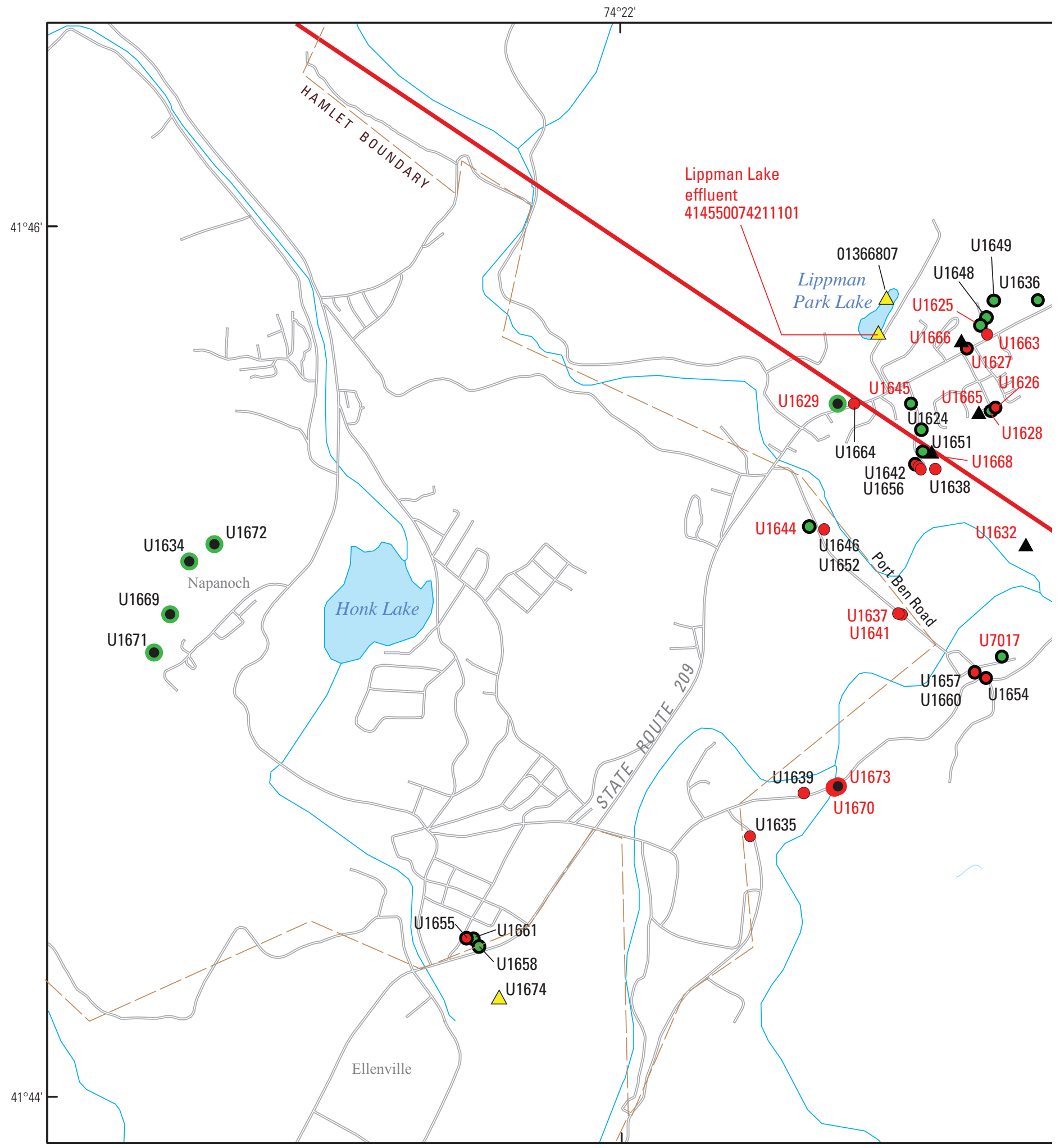

Base from U.S. Geological Survey Digital Data 1:100,000 series Lambert Conformal Conic Projection

North American Datum of 1983

Figure 2. Monitoring sites at a lake (Lippman Lake), springs, unconsolidated monitoring and supply wells, and bedrock supply wells in Wawarsing, Ulster County, New York. (Location is shown in figure 1) 


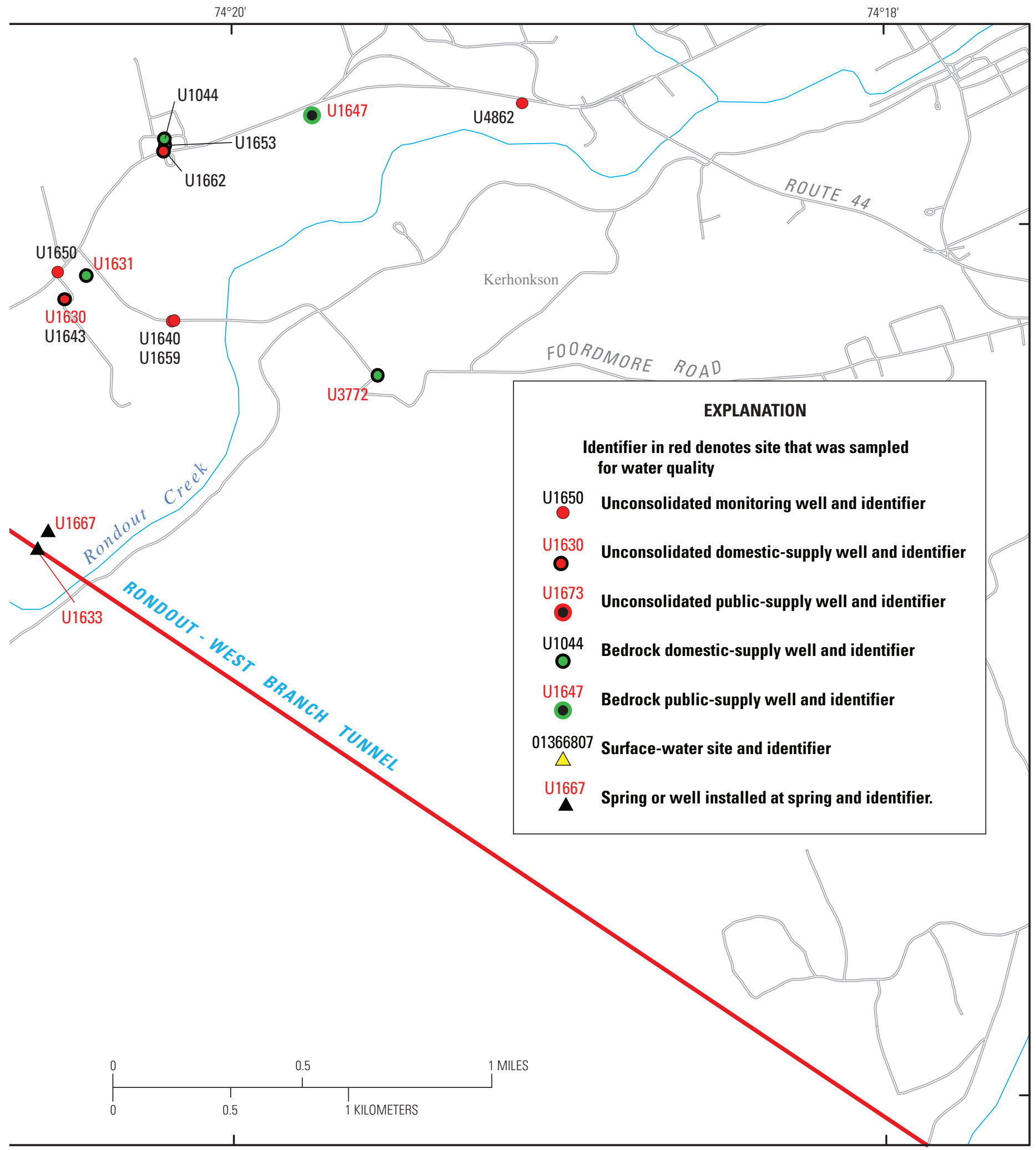

Figure 2. Monitoring sites at a lake (Lippman Lake), springs, unconsolidated monitoring and supply wells, and bedrock supply wells in Wawarsing, Ulster County, New York. (Location is shown in figure 1)-Continued 
Table 1. Data on the sampling-site locations and construction of wells in the Wawarsing study area, and for the Rondout Reservoir at the influent to the Rondout-West Branch Tunnel in Lackawack, Ulster County, New York, 2009-11.

[NAVD 88, North American Vertical Datum of 1988; DSW, domestic supply well; RWB, Rondout-West Branch Tunnel; --, no data; NA, not applicable; MW, monitoring well; CSW, community supply well; NCSW, non-community supply well; SPR, spring; SW, surface water; datum of gage is North American Vertical Datum of 1988]

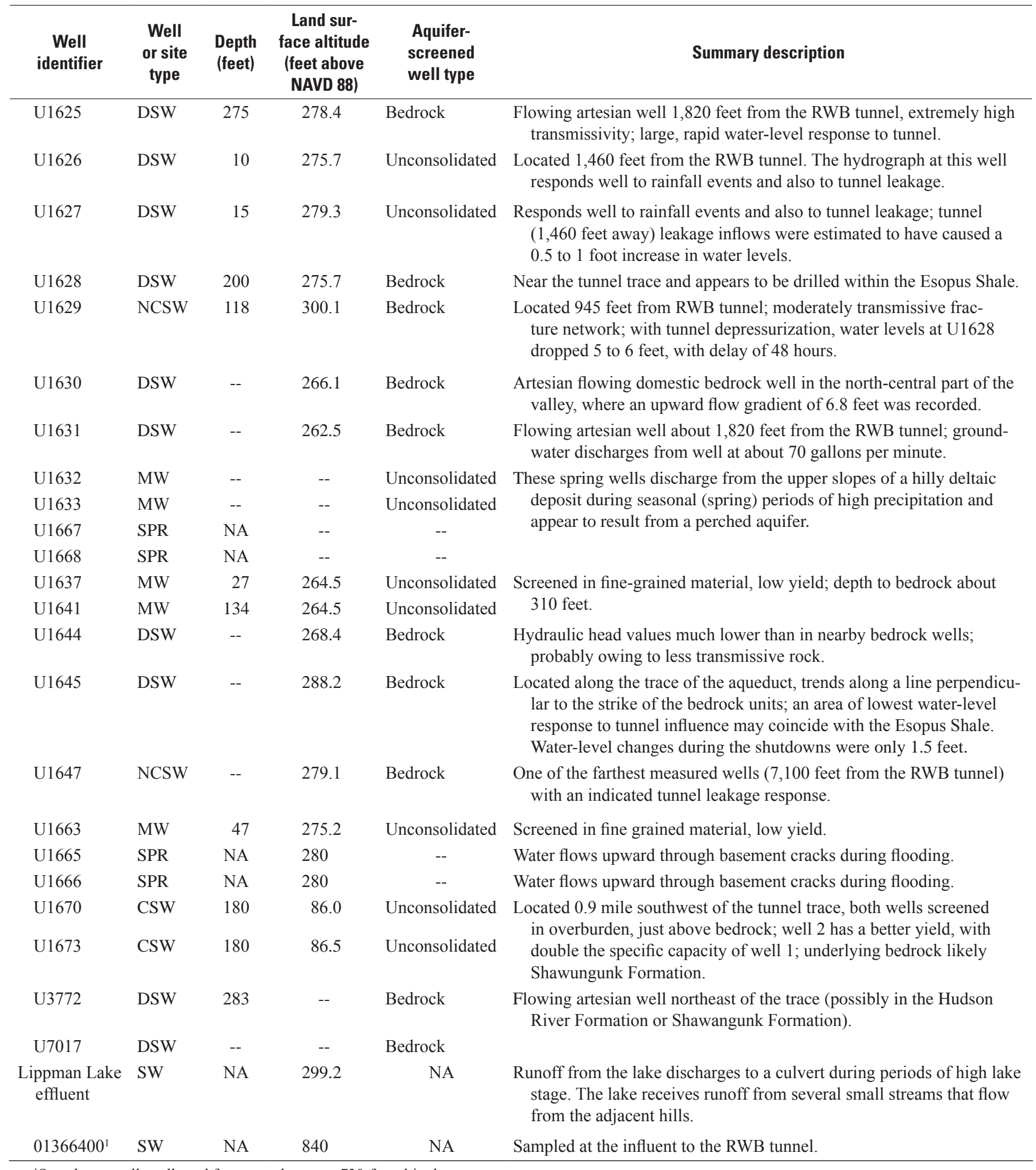

${ }^{1}$ Sample generally collected from sample port at 730 -feet altitude. 
Table 2. Classes of water-quality chemical characteristics and constituents measured in water samples from a lake, springs, and wells in the Wawarsing study area, and for the Rondout Reservoir at the influent to the Rondout-West Branch Tunnel in Lackawack, Ulster County, New York, 2009-11.

[Water-quality field parameters: temperature, $\mathrm{pH}$, specific conductance, dissolved oxygen, dissolved sulfides, alkalinity; O, oxygen; $\mathrm{H}$, hydrogen; $\mathrm{C}$, carbon; ${ }^{87} \mathrm{Sr} r{ }^{86} \mathrm{Sr}$, stable isotope ratio of strontium- 87 to strontium- 86 ; $\delta$, delta; $\delta^{2} \mathrm{H}$ (or " $\delta \mathrm{D}$ "), stable isotope ratio of hydrogen-2 to hydrogen- $1 ; \delta^{18} \mathrm{O}$, stable isotope ratio of oxygen-18 to oxygen-16, relative to Vienna Standard Mean Ocean Water standard; $\delta^{34} \mathrm{~S}$ of $\mathrm{SO}_{4}^{2-}$, stable isotope ratio of sulfur-34 to sulfur-32 of sulfate relative to the Vienna Canyon Diablo Troilite standard; $\delta^{13} \mathrm{C}$ in DIC, stable isotope ratio of C-13 to C-12 in dissolved inorganic carbon relative to the Vienna Pee Dee Belemnite standard; CFCs, chlorofluorocarbons; analyses done by the U.S. Geological Survey (USGS) National Water Quality Laboratory, unless otherwise indicated]

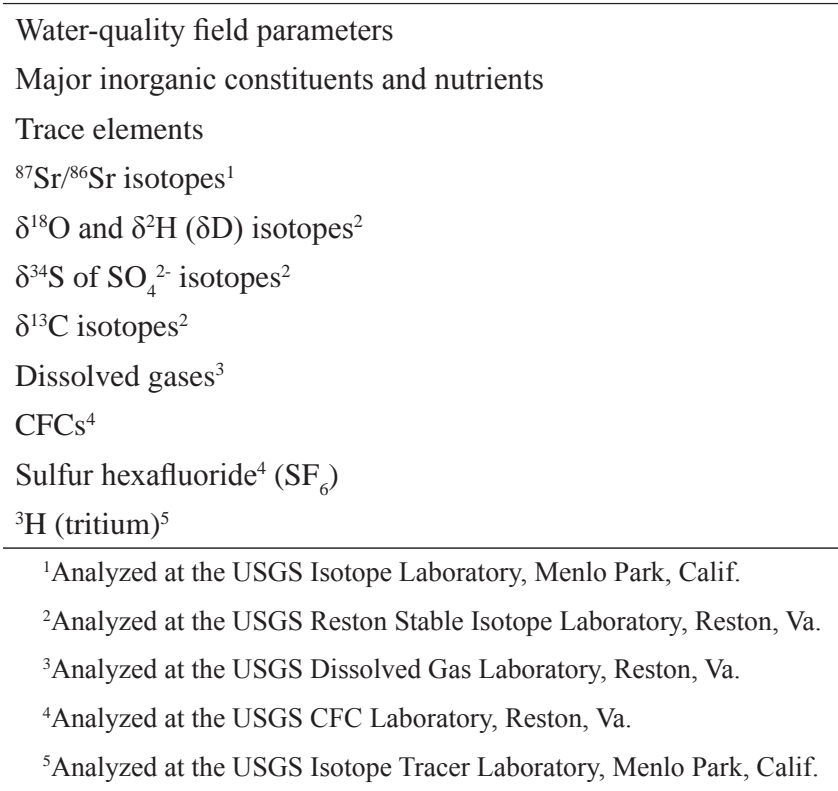

from $\mathrm{N}_{2}$ and Ar gas concentrations in samples. $\mathrm{N}_{2}$ concentrations can be affected by denitrification under denitrifying conditions, but excess $\mathrm{N}_{2}$ was not present.

Groundwater ages were estimated from concentrations of tritium $\left({ }^{3} \mathrm{H}\right)$, chlorofluorocarbons (CFCs, including CFC-11, CFC-12, and CFC-113), and sulfur hexafluoride ( $\left.\mathrm{SF}_{6}\right)$ tracers. Anthropogenic activities, such as industrial processes and atmospheric testing of thermonuclear devices, released ${ }^{3} \mathrm{H}$, $\mathrm{SF}_{6}$, and CFCs into the atmosphere in small but measurable concentrations. Precipitation that incorporates these gases from the atmosphere infiltrates into the ground and carries the particular chemical or isotopic signature of the atmospheric conditions at the time of recharge. These dating methods assume that gas exchange between the unsaturated zone and the atmosphere is fast but that shallow groundwater remains closed to gas exchange after recharge (Schlosser and others, 1989; Plummer and Busenberg, 1999; Busenberg and Plummer, 2000). Where possible, at least two age-dating indicators were measured at sampling sites. Apparent ages were estimated by assuming that piston flow prevails in the aquifer system. Age-tracer samples were collected without headspace, although bubbles of $\mathrm{H}_{2} \mathrm{~S}$ formed in several samples from bedrock wells. If an $\mathrm{H}_{2} \mathrm{~S}$ bubble formed in the sample bottle, the headspace volume was measured and a correction was applied to the calculation of $\mathrm{SF}_{6}$ or $\mathrm{CFC}$ concentrations. The percent uncertainty in sample concentrations was below 3 percent.

The ${ }^{3} \mathrm{H}$ in water was measured at the ${ }^{3} \mathrm{H}$ Laboratory, University of Miami, by internal gas proportional counting of $\mathrm{H}_{2}$-gas made from the water samples. The ${ }^{3} \mathrm{H}$ that was released into the atmosphere between 1952 and 1963 during nuclear weapons tests provides a tracer for rainwater, which allows dates of recharge to be estimated. Although ${ }^{3} \mathrm{H}$ concentrations are approaching that of natural atmospheric production (6 to $15 \mathrm{pCi} / \mathrm{L})$, they remain high enough to use in this analysis. The ${ }^{3} \mathrm{H}$ related to weapons testing can be used to infer some aspects of groundwater age; at the very least, water can be classified as being recharged before or after 1953 .

The CFC samples were collected by inserting the end of the discharge tubing into the bottom of the bottle, allowing at least 2 liters (L) to overflow into a 2-L beaker, then capping the $125-\mathrm{mL}$ glass bottles with special foil-lined caps under water within the beaker. Groundwater samples for $\mathrm{SF}_{6}$ were collected by placing the sampling-discharge line in the bottom of the bottle and displacing the air in the bottle with groundwater. After approximately 2 L of overflow, the sampling line was removed. The bottles were tightly sealed without headspace using conical screw caps and wrapped with electrical tape. 
Concentrations of trichlorofluoromethane (CFC-11), dichlorodifluoromethane (CFC-12), and 1,1,2-trichlorotrifluoroethane (CFC-113) in water were determined at the USGS CFC Laboratory in Reston, Virginia, with a detection limit of about 0.3 picomole per kilogram using purge and trap, gas-chromatographic techniques with electron-capture detector (GC-ECD) (Bullister, 1984; Bullister and Weiss, 1988; Busenberg and Plummer, 1992). The CFC-dating technique is described in Busenberg and Plummer (1992). Samples were analyzed for $\mathrm{SF}_{6}$ at the USGS CFC Laboratory using procedures described by Busenberg and Plummer (2000).

Stable isotopes were analyzed using several different methods. Analyses of the stable-isotope ratios oxygen-18 to oxygen-16 $\left(\delta^{18} \mathrm{O}\right)$, hydrogen-2 to hydrogen- $1\left(\delta^{2} \mathrm{H}\right), \delta^{34} \mathrm{~S}$ of $\mathrm{SO}_{4}^{2-}$, and $\delta^{13} \mathrm{C}$ of DIC were done at the USGS Stable Isotope Laboratory in Reston, Virginia. A hydrogen equilibration method was used for $\delta^{2} \mathrm{H}$ analysis (Coplen and others, 1991), and the $\mathrm{CO}_{2}$ equilibration technique (Epstein and Mayeda, 1953 ) was used for analysis of $\delta^{18} \mathrm{O}$. The 2-sigma analytical uncertainties for $\delta^{2} \mathrm{H}$ and $\delta^{18} \mathrm{O}$ values are 2 and 0.2 per mil, respectively. The $\delta^{34} \mathrm{~S}$ of $\mathrm{SO}_{4}{ }^{2-}$ was analyzed for $\mathrm{BaSO}_{4}$ precipitates using procedures described in Carmody and others (1998). Results are reported in per mil relative to the Vienna Canyon Diablo Troilite (VCDT) standard. The uncertainty associated with $\delta^{34} \mathrm{~S}$ values is \pm 0.2 per mil. Water samples were analyzed for $\delta^{13} \mathrm{C}$ using mass-spectrometry techniques at the University of Waterloo Environmental Isotope Laboratory, Waterloo, Ontario, Canada, and are reported relative to the Vienna Pee Dee Belemnite (VPDB) standard. The uncertainty associated with the $\delta^{13} \mathrm{C}$ values is \pm 0.2 per mil. Ratios of ${ }^{87} \mathrm{Sr} /{ }^{86} \mathrm{Sr}$ were determined by thermal ionization mass spectrometry as described by Bullen and others (1997).

\section{Quality Assurance}

Field probes were cleaned and calibrated with standard solutions and checked periodically with independent field and laboratory probes. Field quality-control procedures included the collection and analysis of replicate samples, which provided information on the variability of analytical results caused by sample collection, processing, and analysis. The charge balances for major ion analyses generally were within \pm 5 percent, although 9 of the 40 samples that were analyzed for major and trace ions had greater imbalances (table 3, in back of report) and could result from (1) ions not included in the analyses, (2) error in laboratory analyses, and (or) (3) error caused by exsolution (degassing) or dissolution of carbon dioxide before sample analysis.

\section{Hydrogeologic Setting}

The geology and hydrology of the bedrock and unconsolidated deposits are discussed in the following section.

\section{Geology}

\section{Bedrock}

A complex series of fractured sedimentary bedrock units of Silurian and Devonian age underlie the unconsolidated deposits in the study area. The bedrock generally strikes northeast and dips about 45 degrees to the northwest. The bedrock units as delineated by Berkey and Fluhr (1936) and Dibbell (1944) include the Marcellus Shale, Onondaga Limestone, Esopus-Schoharie Shale, Helderberg Limestones (Port Ewen-Becraft, New Scotland, Coeymans), Manlius Limestone, Binnewater Limestone and Sandstone, High Falls Shale and Limestone, Wawarsing Wedge complex, Shawangunk Sandstone, and Hudson River Shale. The Marcellus Shale is estimated to have relatively high gasproduction potential and is being considered for extraction in parts of New York, as well as Ohio, Maryland, and large parts of Pennsylvania and eastern West Virginia (Kargbo and others, 2010). The Shawangunk Formation, which caps the Shawangunk Mountains to the east, contacts the overlying Wawarsing Wedge to the west and the underlying Hudson River Shale to the east. Dibbell (1944) describes the bedrock sequences as having sections with substantial fracturing, and faulting in the subsurface below the study area. Many of these fracture and fault zones produced groundwater in thousands of gallons per minute during construction of the RWB Tunnel (figs. 3A and B).

Leakage of water from the RWB Tunnel appears to be from cracks in the liner allowing pressurized tunnel water to flow behind and (or) through the liner where transmissive voids may exist, including solution cavities in limestone, as well as through fractures, faults, and geologic contacts. Sustained leakage of pressurized tunnel water through limestone that contains dissolution features could induce further dissolution of the limestone surrounding the tunnel liner. The Onondaga Limestone was described as being cavernous in many places and members of the Helderberg and Manlius Limestones exhibited a tendency to develop cavernous structures (Berkey and Fluhr, 1936). Transmissive fractures, faults, and bedrock contacts eventually crop out in the subsurface where the unconsolidated deposits may impede or transmit the pressurized RWB Tunnel leakage.

Some of the minerals in the fractured bedrock aquifer system are particularly pertinent to water-chemistry constituents, such as $\mathrm{H}_{2} \mathrm{~S}, \mathrm{CH}_{4}, \mathrm{SO}_{4}^{2-}, \mathrm{Sr}$, and several stable isotopes. For example, evaporites formed during the arid conditions in the late Silurian and the Silurian sedimentary sequence probably functioned as a paleoaquifer (Kesler and others, 1997). Sulfur (S) isotope compositions indicate that the lower part of the paleoaquifer contained reduced $\mathrm{S}$ formed by thermochemical reduction, whereas the upper part of the paleoaquifer contained reduced $\mathrm{S}$ formed by bacterial reduction of $\mathrm{SO}_{4}^{2-}$ derived from overlying Salina Group evaporites. These constraints, along with $\mathrm{Na}-\mathrm{Cl}-\mathrm{Br}$ leachate 
data, indicate that Mississippi Valley Type mineralization in the Lockport Dolomite formed when rising, metal-bearing brines mixed with descending, sulfur-bearing brines from the Salina Group above (Kesler and others, 1997). Vein deposits of zinc, lead, and copper sulfides are present to the east, on the west slope of the Shawangunk Mountains (Heusser, 1976), in a northeast-trending belt $24 \mathrm{mi}$ long, extending from Guymard to Ellenville, N.Y. (Wilbur and others, 1990). These deposits mark the eastern margin of the evaporite-bearing Silurian sedimentary basin and were observed during completion of the Delaware Aqueduct (Bird, 1944).

\section{Unconsolidated Deposits}

The valley in the study area is underlain by surficial deposits of gravel, sand, silt, and clay, and include Pleistocene glacial stratified and till deposits, and Holocene alluvium deposits, which are present primarily in stream channels. The major unconsolidated hydrogeologic units consist of till, icecontact stratified drift, outwash, glacial lake clays, recent alluvium, and colluvium. Reynolds (2007) and Frimpter (1972) described a sand and gravel aquifer buried beneath glacial lake sediments. Geologic data from 14 USGS-drilled monitoring wells within the study area indicate highly variable deposits ranging from sand and gravel to silt and clay and lacustrine clay deposits that exceed $140 \mathrm{ft}$ in thickness in some areas (Frederick Stumm, U.S. Geological Survey, written commun., 2010). Preliminary analysis of unpublished USGS passive seismic surveys and deep electromagnetic geophysical surveys of the study area indicate that the bedrock contact is undulating with areas of deep erosional troughs. These deep troughs are northeast-southwest trending and extend more than $300 \mathrm{ft}$ below land surface.

\section{Hydrology}

Randall (1996) studied the precipitation variations in upstate New York and determined that the Wawarsing study area averaged about 44 inches (in.) of precipitation annually during 1951-80. This study is consistent with the long-term daily precipitation records recorded by the National Weather Service (NWS) at Central Park in New York City (National Oceanic and Atmospheric Administration, 2010), and indicates only slight variations owing to localized storms. Annual precipitation exceeded the long-term mean every year during $2002-10$. The increase in precipitation has caused increased groundwater levels and contributed to surface flooding when the rate of precipitation exceeded drainage from roadways or recharge into surficial deposits (Stumm and others, 2012).

Groundwater generally flows from the surrounding hills east and west of the valley and from southwest of the valley toward the central and ultimately northeastern part of the valley. Hydrographs from wells screened in unconsolidated deposits indicate a direct correlation to precipitation but also some effects caused by tunnel leakages from underlying bedrock (Stumm and others, 2012). Analysis of the vertical gradients between the deeper and shallower parts of the unconsolidated aquifer indicate an upward-flow gradient, particularly in the central parts of the valley where the water table discharges to Rondout Creek and the deposits are thickest (Stumm and others, 2012).

For bedrock wells, the highest water levels were recorded in March and April of 2009 and 2010 during periods of elevated precipitation (Stumm and others, 2012). The bedrock potentiometric surface was higher locally in the area along State Route 209 as a result of tunnel leakage (Stumm and others, 2012). Most bedrock wells affected by tunnel leakage had upward-flow gradients from the bedrock to the unconsolidated aquifer. The head differential between the bedrock and unconsolidated aquifers at wells U1627 and $\mathrm{U} 1625$ was $10.6 \mathrm{ft}$, and the flow gradient direction was upward (Stumm and others, 2012).

The majority of homes in Wawarsing rely upon domesticsupply wells in the unconsolidated and bedrock aquifers. Major municipal-water users in this area include the Village of Ellenville $(4,400)$ and the Eastern New York Correctional Facility (700), totaling about 5,000 municipal groundwater users (New York State Department of Health, 1982). The transmissivity of the aquifer near Ellenville appears to be very high, as evidenced by a 39-ft deep supply well for the village of Ellenville that initially had a pumping rate of $1,000 \mathrm{gal} / \mathrm{min}$ (Frimpter, 1972).

\section{Water-Quality Monitoring Sites}

Water-quality monitoring sites sampled in Wawarsing include four springs, seven wells screened in unconsolidated deposits, and six wells in bedrock, in addition to the lake site at Lippman Park. Manual measurements of groundwater levels were completed monthly, and levels at selected wells were recorded hourly with pressure transducers and data loggers, as described in Stumm and others (2012). Groundwater temperatures in wells U1625, U1630, U1649, and U1651 were the lowest among the monitored bedrock wells and are consistent with the leakage of colder tunnel water into the surrounding fractured-bedrock groundwater-flow system along highly transmissive sections (Stumm and others, 2012). Bedrock wells with the coldest groundwater temperatures were the same wells that had the largest water-level changes and shortest delay times to tunnel influences.

\section{Rondout Reservoir and the Rondout-West Branch Water Tunnel}

Rondout Reservoir water was sampled at the influent to the RWB Tunnel, which carries water from the Rondout Reservoir to the Kensico Reservoir and then on to NYC (fig. 1). Sample analysis of this water was used to represent water chemistry in the tunnel. Water in the Rondout Reservoir results from precipitation in the contributing Delaware and 


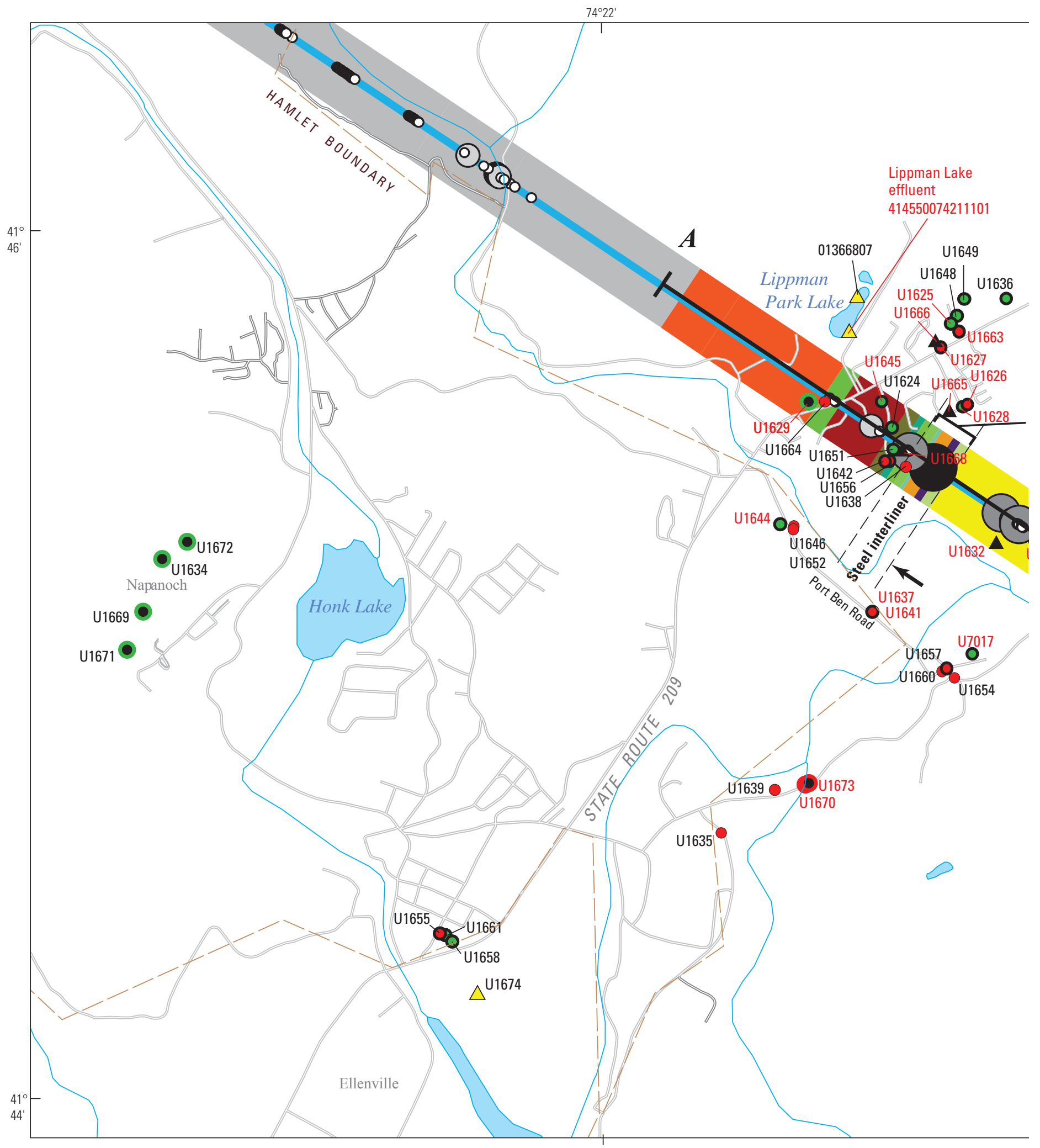

Base from U.S. Geological Survey Digital Data 1:100,000 series Lambert Conformal Conic Projection

North American Datum of 1983

Figure 3A. A. Locations of wells and surface-water sites; Rondout-West Branch Tunnel geology; and water-inflow rates documented during tunnel construction in the Wawarsing study area, Ulster County, New York. (Modified from Stumm and others, 2012) (Location is shown in figure 1; LS, limestone; SS, sandstone; SH, shale). 


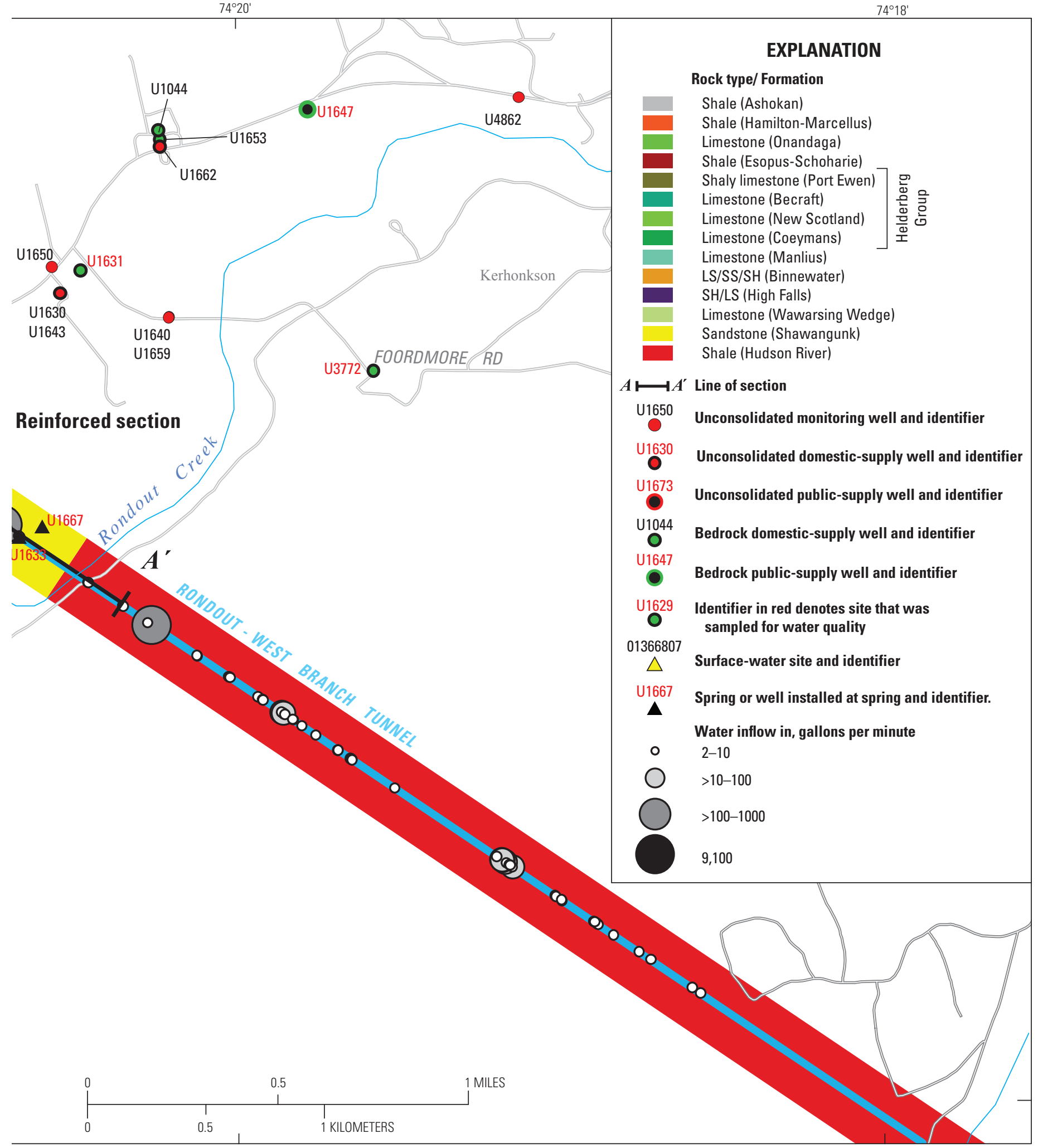

Figure 3A. A. Locations of wells and surface-water sites; Rondout-West Branch Tunnel geology; and water-inflow rates documented during tunnel construction in the Wawarsing study area, Ulster County, New York. (Modified from Stumm and others, 2012) (Location is shown in figure 1; LS, limestone; SS, sandstone; SH, shale).-Continued 


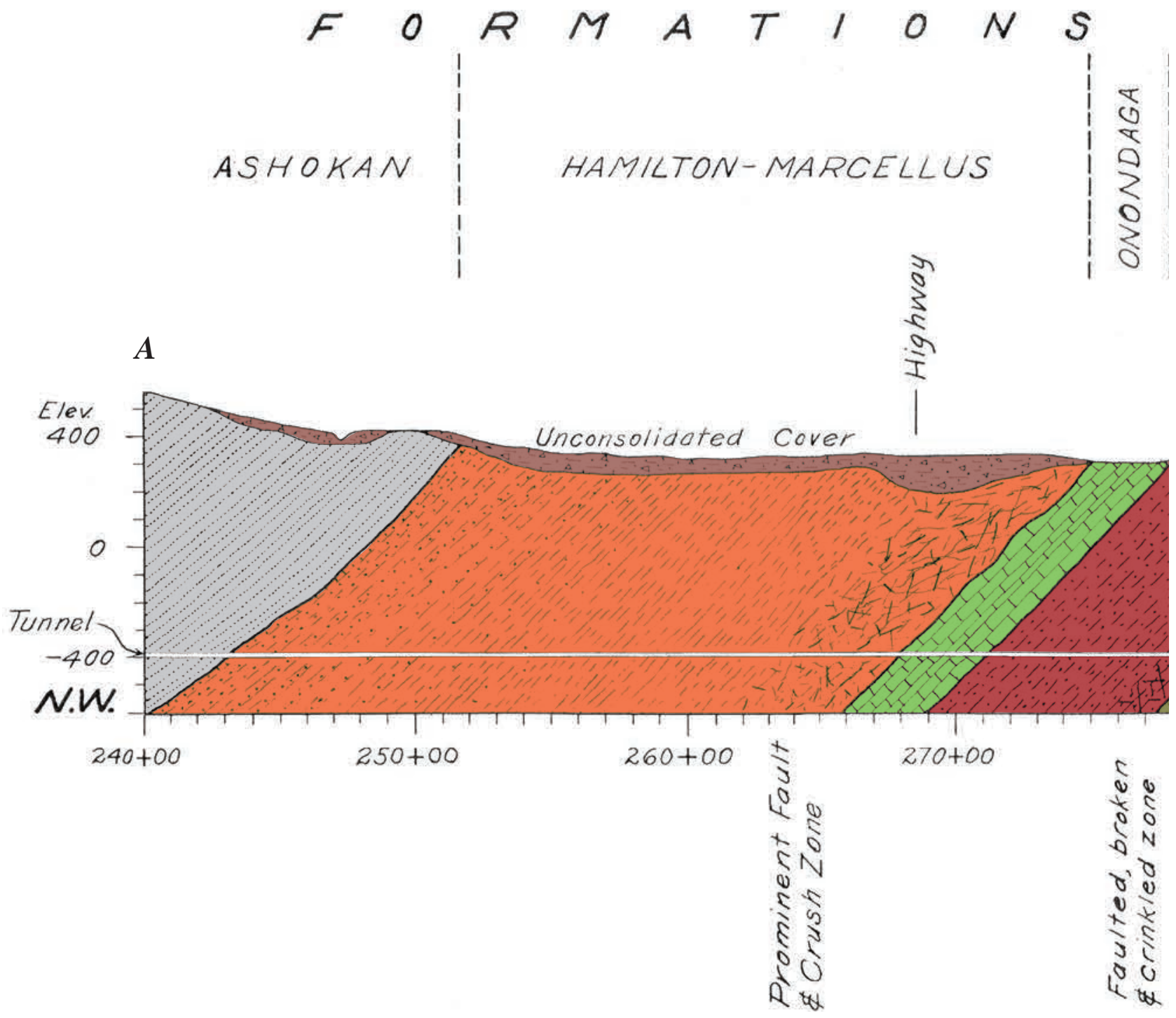

Figure 3B. B. Cross section of geology observed during New York City Board of Water Supply test borings and Rondout-West Branch Tunnel construction from A to A' within the study area, Town of Wawarsing, Ulster County, New York. (Location is shown in figure 3A) (The Helderberg Group has been divided into the Port Ewen, Becraft, New Scotland, and Coeymans Formations) (Modified from Berkey and Fluhr, 1936). 


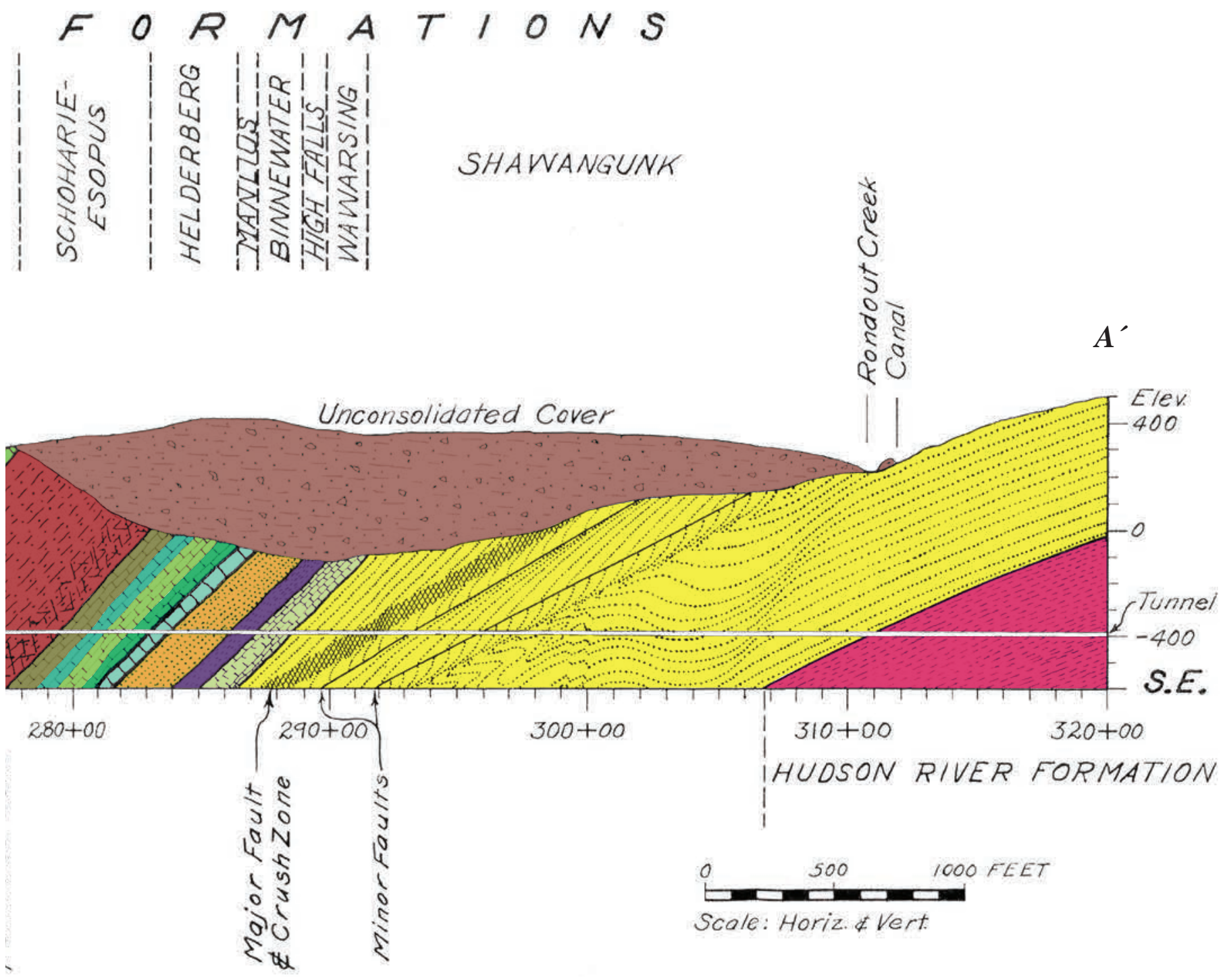

Figure 3B. B. Cross section of geology observed during New York City Board of Water Supply test borings and Rondout-West Branch Tunnel construction from A to $A^{\prime}$ within the study area, Town of Wawarsing, Ulster County, New York. (Location is shown in figure 3A) (The Helderberg Group has been divided into the Port Ewen, Becraft, New Scotland, and Coeymans Formations) (Modified from Berkey and Fluhr, 1936).-Continued 
Catskill watersheds. The Rondout Reservoir is located $75 \mathrm{mi}$ northwest of NYC in the Catskill Mountains between the towns of Wawarsing in Ulster County and Neversink in Sullivan County. The reservoir is the central collection point for the Delaware System and provides about one-half of the daily consumption for NYC.

The Rondout Reservoir is $6.5 \mathrm{mi}$ long and $3.2 \mathrm{mi}^{2}$ in area and reaches a maximum depth of $175 \mathrm{ft}$ near the dam; the mean depth is $73.8 \mathrm{ft}$, and the altitude is $840 \mathrm{ft}$ above NAVD 88 (Effler and others, 2001). The Rondout Reservoir holds 49.6 billion gallons, which comes from the $95-\mathrm{mi}^{2}$ Rondout Creek watershed, as well as from the Cannonsville, Neversink, and Pepacton Reservoirs via the Delaware and Neversink Tunnels. Because those three reservoirs are in the Delaware River watershed, Rondout is considered by the city's Department of Environmental Protection to be part of the Delaware System despite being entirely within the Hudson River watershed. Rondout is circumscribed by State Routes 55 and $55 \mathrm{~A}$, but access to the actual reservoir is tightly restricted.

Specific conductance in the Rondout Reservoir generally is lower than in the Pepacton and Cannonsville Reservoirs, but higher than in the Neversink Reservoir (Owens, 1998; Effler and others, 2001). Specific conductance and temperature in the Rondout Reservoir did not vary substantially in lateral directions (Effler and O'Donnell, 2001). The Rondout Reservoir undergoes thermal stratification during summer, although not extensively because of the large contributions of cold water received from the upstream reservoirs. The Rondout Reservoir has a drawdown of $35 \mathrm{ft}$ (10.8 meters) and a flushing rate of 6.8 times per year (Effler and others, 2001).

\section{Hydrologic Effects of Temporary Rondout-West Branch Water Tunnel Shutdowns}

The NYCDEP shut down the RWB Tunnel on four separate occasions from October 2008 to December 2010 (Stumm and others, 2012) and three times during the period of water-quality sampling, December 2009 to April 2010. The four shutdowns occurred (1) October 25-November 26, 2008, (2) November 5-19, 2009, (3) December 4-16, 2009, and (4) January 13-26, 2010. During each of the shutdowns, the tunnel pressure was slowly reduced from about 600 to about $75 \mathrm{ft}$ above NAVD 88 over a period of 34 to 56 hours, as measured in a nearby tunnel shaft. The re-pressurization process was accomplished in the same manner, by increasing the pressure in the RWB Tunnel from about 75 to about $600 \mathrm{ft}$ above NAVD 88, over a period of 43 to 54 hours.

A number of wells screened in unconsolidated deposits and in bedrock in Wawarsing indicated water-level changes in response to tunnel pressure (Stumm and others, 2012). The location of unconsolidated aquifer wells with measureable changes to tunnel leakage correlated with those in the bedrock. Water levels in the bedrock changed as much as $12 \mathrm{ft}$ within 0.5 hour during tunnel shutdowns, although the majority of bedrock wells influenced by tunnel leakage indicated lag times of 21 to 33 hours. RWB Tunnel leakage has been documented to enter the bedrock units adjacent to the tunnel and cause increases in the bedrock water levels by as much as $10.5 \mathrm{ft}$ (Stumm and others, 2012). Transmissive fractures in the bedrock near the contact between the unconsolidated and bedrock aquifers can transmit this increased pressure to the overlying unconsolidated aquifer.

Water-level changes in bedrock wells during the shutdowns ranged from $12 \mathrm{ft}$ at $\mathrm{U} 1625$ to $1.5 \mathrm{ft}$ at U1645, and well U1629 indicated no change (Stumm and others, 2012). The greater water-level responses in units on either side of these wells appear to correlate with the limestone units in contact with the shale (Stumm and others, 2012). Analysis of the hydrographs at U1625 during the tunnel shutdowns indicates the bedrock in this area responds within about 0.5 hour of tunnel depressurization or re-pressurization (fig. 11B in Stumm and others, 2012). The rapid response times to changes in tunnel pressure, the large water-level changes, and the considerable distance from the tunnel may indicate the existence of an interconnected cave or dissolution fracture system with large storage and transmissivity characteristics. Well U1647, located 7,100 ft from the RWB Tunnel, was one of the farthest measured wells with a tunnel-leakage response. Bedrock wells U1628 and U1631 had among the longest lag times: 48 and 60 hours, respectively (Stumm and others, 2012). Well U1628 is near the tunnel and appears to be drilled within the Esopus Shale, a fine-grained rock unit that could have limited transmissivity and connectivity (fig. 3).

Water levels in the unconsolidated deposits changed as much as $2.5 \mathrm{ft}$ within 18 hours during tunnel shutdowns (Stumm and others, 2012). The location of wells in the unconsolidated aquifer with measurable changes caused by tunnel leakage correlated with those in the bedrock, including some at distances of 7,000 ft from the RWB Tunnel (Stumm and others, 2012). A hydrograph of well U1641 indicates a drop in water levels of 2 to $2.5 \mathrm{ft}$ during each of the last three shutdowns. The tunnel-leakage influence lag time at this overburden well was only about 18 hours, indicating that the bedrock, which is about $170 \mathrm{ft}$ deeper than well U1641, must consist of highly transmissive fractures that respond quickly to tunnelpressure changes (Stumm and others, 2012). Tunnel-leakage inflows at U1626 were estimated to have caused a 0.5 to $1 \mathrm{ft}$ increase in water levels in the unconsolidated aquifer at this well (Stumm and others, 2012).

\section{Water Sources and Chemistry}

Anthropogenic and natural sources of water can be characterized based on water chemistry, age tracers, and stable isotopes. Data analysis included graphical plotting of concentrations of water-quality constituents and pertinent plots of constituent and isotope ratios. 


\section{Sources of Water}

Groundwater chemistry is primarily affected by atmospheric deposition; weathering of soil and aquifer material; and anthropogenic sources, such as road salt, septic-system leachate, leaking underground-storage tanks, landfills, chemical spills, and storm-water runoff from roads and parking lots. Several analysis tools were used to help distinguish (1) anthropogenic sources or pathways from natural ones and (2) surface water or shallow groundwater from deep groundwater, including Piper diagrams, scatterplots (not shown), saturation indexes for calcite and gypsum, stable isotopes, dissolved gases, and groundwater-age tracers. Differences in chemical signatures among the parts of the hydrologic system were used to improve the understanding of source waters and groundwater-flow patterns and pathways and can be used to assess mixing of the different source waters in samples.

\section{Major Constituents and Nutrients}

Major-ion concentrations in water samples collected during the study show differences depending on the sample type, depth, and location (table 3 , in back of report). The Piper diagram (Piper, 1944) is used to show the clustering of samples by water type and the effects of aquifer weathering and anthropogenic activities on major-ion concentrations; samples are represented by the percentages of total cations and total anions, plotted on separate trilinear plots, and then projected onto a central diamond (fig. 4).

The anion percentages in water samples from most unconsolidated aquifer wells and springs were greater in $\mathrm{HCO}_{3}{ }^{-}$and carbonate $\left(\mathrm{CO}_{3}{ }^{2}\right)$ than in $\mathrm{SO}_{4}{ }^{2-}$ and chloride compared to the bedrock well samples; the lower concentrations of $\mathrm{HCO}_{3}{ }^{-}$in deep groundwater could result from the precipitation of calcite. Similarly, water samples from most unconsolidated aquifer wells and springs had a greater percentage of calcium (Ca) compared to other cations than did bedrock well samples. The exception was the water sample from U1625, which had high ratios of $\mathrm{HCO}_{3}$ and $\mathrm{Ca}$ relative to other ions, and similar to other samples, such as unconsolidated aquifer well samples and surface-water samples (fig. 4). Water samples from bedrock wells generally had relatively high concentrations of $\mathrm{SO}_{4}^{2-}$ compared to other anions; samples from two bedrock wells that did not have high concentrations of $\mathrm{SO}_{4}^{2-}$ were reducing and had high concentrations of dissolved $\mathrm{H}_{2} \mathrm{~S}$. High concentrations of $\mathrm{SO}_{4}{ }^{2-}$ are not uncommon in groundwater from the Silurian-Devonian bedrock, which is likely due to the presence of gypsum in the upper part of the Silurian sequence (Williams and Eckhardt, 1987).

Nitrate $\left(\mathrm{NO}_{3}^{-}\right)$plus nitrite $\left(\mathrm{NO}_{2}^{-}\right)$in water samples can be derived from several sources, including microbial decay of organic matter in soils, animal waste, septic-system leachate, synthetic fertilizers, and rainfall. Concentrations of $\mathrm{NO}_{3}^{-}$plus $\mathrm{NO}_{2}{ }^{-}$ranged from less than the minimum reporting levels
(MRLs) in water samples with reducing redox characteristics to $0.88 \mathrm{mg} / \mathrm{L}$ as $\mathrm{N}$ for a domestic well in a residential area with onsite septic-tank drainfields (table 3, in back of report). Concentrations of $\mathrm{NO}_{2}^{-}$were less than the MRL of $0.008 \mathrm{mg} / \mathrm{L}$ as $\mathrm{N}$ in all but two samples; therefore, $\mathrm{NO}_{3}{ }^{-}$plus $\mathrm{NO}_{2}{ }^{-}$is hereafter referred to as $\mathrm{NO}_{3}^{-}$. The median concentration of $\mathrm{NO}_{3}{ }^{-}$for wells in the study area was less than $0.5 \mathrm{mg} / \mathrm{L}$ as N, and samples at more than one-half of the sites were below the reporting level of $0.04 \mathrm{mg} / \mathrm{L}$ as N. Urban septic-system leachate and lawn fertilizer are the major sources of $\mathrm{NO}_{3}{ }^{-}$in the study area and can affect shallow groundwater quality. Although $\mathrm{NO}_{3}{ }^{-}$from septic systems does not appear to be a health concern, bacterial contamination of private-supply wells with Escherichia coli (E. coli) is a recurring problem in the Rondout Valley near the town of Wawarsing (J.T. Rodden, Jr., Ulster County Health Department, written commun., 2009). The presence of E. coli in domestic well water is likely caused by the mobilization of septic-system leachate by the high water table associated with seasonal flooding.

Saturation indexes, which are represented by the logarithms of the ratios of the ion activity products to the solubility product constants, or $\log$ (IAP/Ksp), indicated that groundwater samples from bedrock wells were at or near saturation with respect to gaseous $\mathrm{CO}_{2}$, quartz, calcite, and dolomite, and undersaturated with respect to gypsum and fluorite (table 3, in back of report). Groundwater samples from most bedrock wells generally were nearer to saturation of calcite and gypsum than groundwater samples from unconsolidated wells (fig. 5). The U1625 well sample that was collected at the RWB Tunnel during low-head pressure on December 14, 2009, shows similar chemistry to that of other bedrock wells; however, samples that were collected on June 24, 2009, and April 7, 2011, from well U1625 under normal tunnel-pressure conditions, when the tunnel pressure was high, had chemistry that was similar to shallow groundwater or surface water (fig. 5). Similarly, the U1631 well sample that was collected at the RWB Tunnel during low-head pressure on December 14, 2009, was supersaturated with respect to calcite, yet was undersaturated in the sample collected on September 16, 2009, when the tunnel pressure was high. These differences in bedrock groundwater chemistry between normal and depressurized tunnel conditions indicate that tunnel water does influence native groundwater under normally pressurized tunnel conditions.

\section{Redox Conditions}

Redox reactions affect many chemical processes in aquifers, including the concentrations of dissolved gases, such as $\mathrm{O}_{2}, \mathrm{~N}_{2}, \mathrm{H}_{2} \mathrm{~S}$, and $\mathrm{CH}_{4}$; speciation and mobility of naturally occurring elements, such as Fe, Mn, S, As, and U; and the transformation of anthropogenic compounds, such as $\mathrm{NO}_{3}^{-}$, chloroform, and trichloroethylene. Redox conditions tend to proceed along a well-documented sequence of zones dominated by a single electron-accepting process. Water-quality 


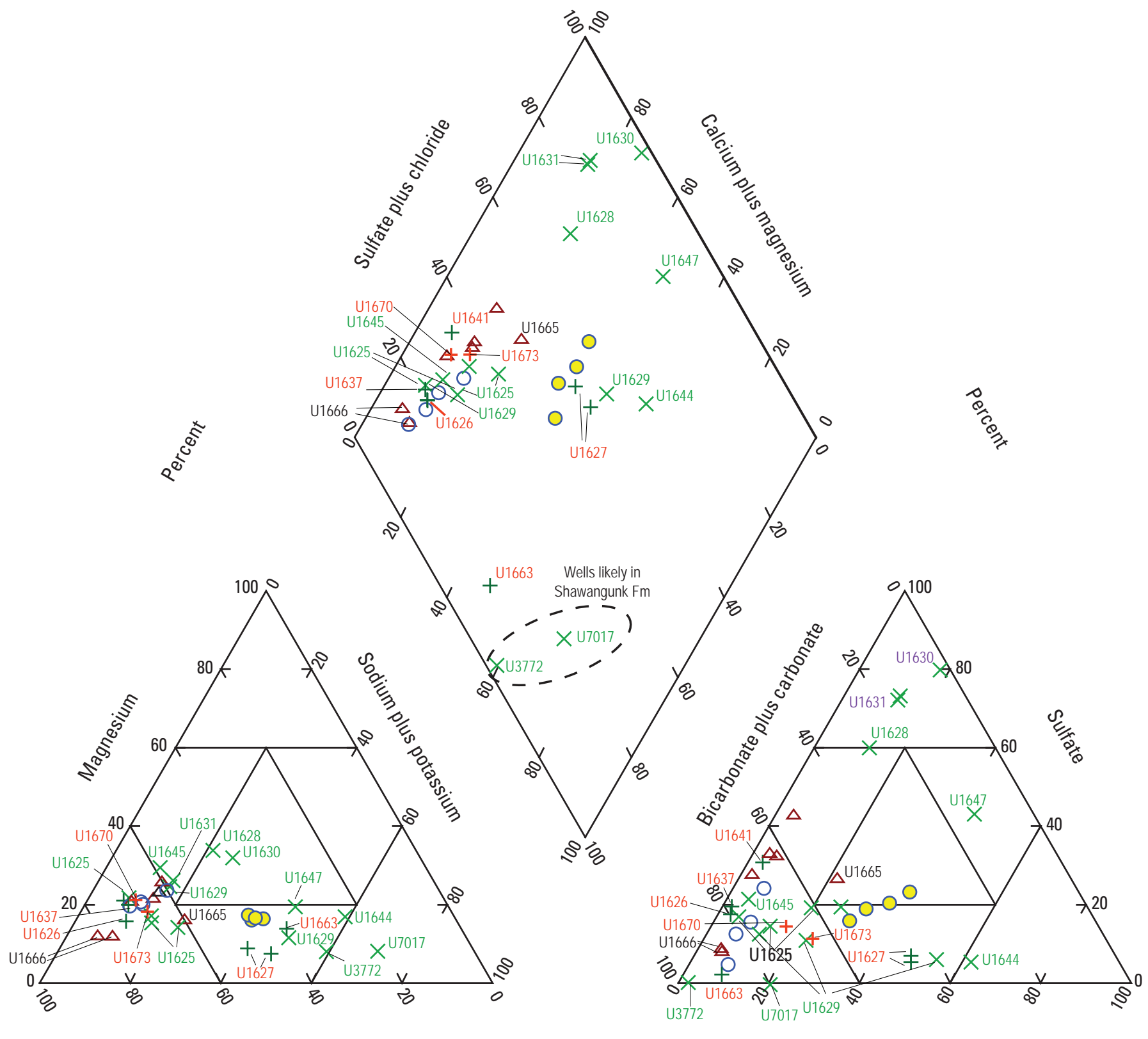

Calcium

Percent

Chloride

EXPLANATION

○ Lippman Lake effluent

O Rondout Reservoir, influent to RondoutWest Branch Tunnel (01366400)

$\Delta$ Spring

U1641 Well, unconsolidated and identifier

$\stackrel{+}{\times}{ }^{+}$Well, bedrock and identifier

Figure 4. The percentage of total equivalents of major cations and anions in surface-water and groundwater samples collected from a lake, springs, and wells in Wawarsing and for the Rondout Reservoir at the influent to the Rondout-West Branch Tunnel in Lackawack, Ulster County, New York, 2009-11. 


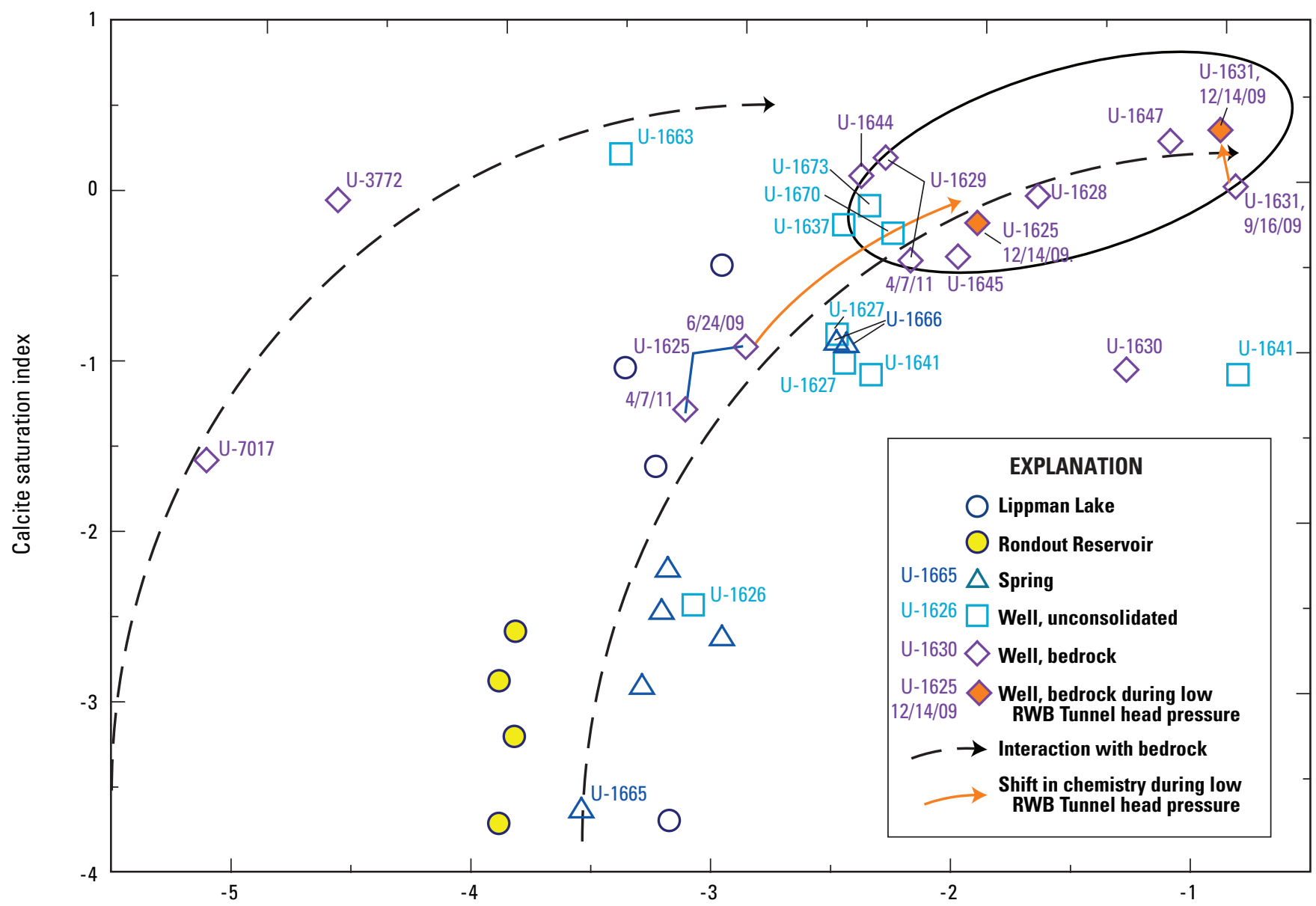

Gypsum saturation index

Figure 5. Saturation indexes for calcite and gypsum in surface-water and groundwater samples collected from a lake, springs, and wells in the study area, Wawarsing, New York, and for the Rondout Reservoir at the influent to the Rondout-West Branch (RWB) Tunnel in Lackawack, Ulster County, New York, 2009-11.

data can be used to assess ambient-redox processes in groundwater systems (McMahon and Chapelle, 2007). DO produces more energy per mole of organic carbon oxidized than any other commonly available electron acceptor; thus, it is used preferentially by surface and subsurface microorganisms. Because groundwater systems can be isolated from the atmosphere, however, $\mathrm{O}_{2}$ tends to be consumed along aquifer flow paths. Under anoxic conditions, the next most energetically favorable naturally available electron acceptor is $\mathrm{NO}_{3}^{-}$, followed by manganese (IV) [Mn(IV)], ferric iron [Fe(III)], sulfate $\left(\mathrm{SO}_{4}^{2-}\right)$, and finally carbon dioxide $\left(\mathrm{CO}_{2}\right)$. This order of preferential electron acceptor utilization $-\mathrm{O}_{2}>\mathrm{NO}_{3}^{-}>\mathrm{Mn}(\mathrm{IV})$ $>\mathrm{Fe}(\mathrm{III})>\mathrm{SO}_{4}{ }^{2-}>\mathrm{CO}_{2}-$ is referred to as the ecological succession of terminal electron-accepting processes (TEAPs). These predominant TEAPs, from more oxidizing to reducing, are $\mathrm{O}_{2}$-reducing (also referred to as oxic in this report), $\mathrm{NO}_{3}^{-}$-reducing, Mn-reducing, Fe-reducing, $\mathrm{SO}_{4}^{2-}$-reducing, and methanogenic (containing methane or $\mathrm{CH}_{4}$ ). Some common contaminants of groundwater systems, such as chlorinated ethenes, also may act as electron acceptors.

A redox classification scheme described by McMahon and Chapelle (2007) and modified by Chapelle and others (2009) uses various chemical indicator species to classify redox conditions in each groundwater sample. The scheme has been modified for this study based on available data for $\mathrm{N}_{2}, \mathrm{H}_{2} \mathrm{~S}$, and $\mathrm{CH}_{4}$ (table 4 , in back of report). In several instances, conflicting or overlapping indicators of redox conditions occur and are related to mixtures of water with different redox indicators but also may indicate disequilibrium among redox indicators; therefore, the term is used whereby $\mathrm{Y} / \mathrm{Z}$ indicates waters with different redox ranging from most oxidized (Y) to most reduced ( $\mathrm{Z}$ ). $\mathrm{CH}_{4}$ was present in water samples from bedrock wells, including high concentrations (greater than $1 \mathrm{mg} / \mathrm{L}$ ) in samples from U1629, U1647, U7017, 
U3772, and U1644 (table 4, in back of report). The Devonian bedrock sequence includes the black shales of the Esopus and Marcellus Formations, which are organic rich, so the presence of $\mathrm{CH}_{4}$ is not surprising.

Redox conditions in the study area ranged from oxic in surface water and most wells screened in unconsolidated deposits to reducing in those wells screened in poorly permeable unconsolidated deposits and in bedrock (table 4, in back of report). Bedrock wells typically have long, open sections that could have had water contributed from several fractures with different flow-path histories. For example, bedrock well U1631 had DO concentrations greater than $1 \mathrm{mg} / \mathrm{L}$, yet also had high concentrations of reduced species, including dissolved $\mathrm{Fe}, \mathrm{Mn}, \mathrm{H}_{2} \mathrm{~S}$, and $\mathrm{CH}_{4} \cdot \mathrm{CH}_{4}$ is not included as a redox variable for the redox classification system used, but its presence in groundwater indicates a contribution of water with very reducing conditions. Most of the bedrock wells were reducing, with the exception of well U1625; concentrations of DO were greater than $2 \mathrm{mg} / \mathrm{L}$ in well $\mathrm{U} 1625$, but $\mathrm{CH}_{4}$ was present in the second sample collected on December 14, 2009, during a tunnel shutdown (table 4, in back of report).

\section{Trace Constituents}

Concentrations of trace constituents, including $\mathrm{Fe}, \mathrm{Mn}$, $\mathrm{As}, \mathrm{Sr}, \mathrm{Ba}, \mathrm{B}, \mathrm{Li}, \mathrm{Ni}$, and $\mathrm{Pb}$, were generally higher in water samples from bedrock wells than in water samples from wells screened in unconsolidated deposits, RWB Tunnel water, or Lippman Lake (table 5, in back of report). High concentrations of dissolved Mn and (or) Fe reflect anoxic conditions, and one or both exceeded U.S. Environmental Protection Agency secondary drinking-water standards of 50 micrograms per liter $(\mu \mathrm{g} / \mathrm{L})$ and $300 \mu \mathrm{g} / \mathrm{L}$, respectively, at several wells (table 5, in back of report; U.S. Environmental Protection Agency, 2006a). Mn concentrations in water samples ranged from less than 0.2 to $660 \mu \mathrm{g} / \mathrm{L}$; samples from 7 of the 10 bedrock wells and 5 of the 7 unconsolidated wells had exceedances of the secondary maximum contaminant level (MCL) (table 5, in back of report). Fe concentrations in water samples ranged from less than 4 to $1,800 \mu \mathrm{g} / \mathrm{L}$; samples from 4 of the 10 bedrock wells and only 1 of the 7 unconsolidated wells had exceedances of the secondary MCL (table 5, in back of report). Concentrations of dissolved As in water sampled from domestic bedrock well U1645 was at the MCL of $10 \mu \mathrm{g} / \mathrm{L}$ (U.S. Environmental Protection Agency, 2006b). Sr concentrations were high in several bedrock wells, ranging up to $20 \mathrm{mg} / \mathrm{L}$ at $\mathrm{U} 1630$ and U1631. High concentrations (greater than $1 \mathrm{mg} / \mathrm{L}$ ) of dissolved $\mathrm{Zn}$ were observed in groundwater samples from drive-point wells that were previously installed by a consultant. Zn concentrations in samples from U1632 (spring) and U1633 (spring) were 2 and $5.3 \mathrm{mg} / \mathrm{L}$, respectively, whereas $\mathrm{Zn}$ concentrations detected in all other samples were below $6 \mu \mathrm{g} / \mathrm{L}$. These high $\mathrm{Zn}$ concentrations in the springs likely originated from the galvanized drive-point wells.

\section{Stable Isotopes}

Stable isotopes were analyzed to help determine different chemical sources that affect flooding and the amount of mixing of the waters. The sources may have different isotopic signatures because of the type of source or chemical fractionation related to evaporative or chemical processes. Stable isotopes measured from constituents in water samples include $\delta^{18} \mathrm{O}, \delta^{2} \mathrm{H}, \delta^{34} \mathrm{~S}$ of $\mathrm{SO}_{4}{ }^{2-},{ }^{87} \mathrm{Sr} /{ }^{86} \mathrm{Sr}$, and $\delta^{13} \mathrm{C}$ of DIC (table 5, in back of report).

The $\delta^{18} \mathrm{O}$ and $\delta^{2} \mathrm{H}$ data for the study area generally plotted along an inferred local meteoric water line (LMWL) that was drawn through groundwater samples collected from sites in Wawarsing (not shown); the LMWL reflects the isotopic signature of local precipitation (Kendall and Coplen, 2000). Most groundwater and surface-water samples from Wawarsing plotted along a line with a slope of about 7.5. Water samples from the Rondout Reservoir plot along a slightly different meteoric water line (MWL), mostly due to seasonal evaporation that varies in intensity as summer progresses, which causes a linear pattern that deviates from the local line. The $\delta^{18} \mathrm{O}$ and $\delta^{2} \mathrm{H}$ values in RWB Tunnel water vary seasonally as a result of evaporative concentration of the heavier isotopes, ${ }^{18} \mathrm{O}$ and ${ }^{2} \mathrm{H}$. Water samples collected during the warmer months are distinctly heavier in $\delta^{18} \mathrm{O}$ and $\delta^{2} \mathrm{H}$ values than those in water from the RWB Tunnel and water from bedrock wells. Values of $\delta^{18} \mathrm{O}$ and $\delta^{2} \mathrm{H}$ in rainfall also vary locally and at different altitudes (Coplen and Kendall, 2000); the higher altitude at the Rondout Reservoir (840 ft NAVD 88) compared to the Wawarsing study area (about $280 \mathrm{ft}$ NAVD 88 ) could account for part of this deviation.

The isotope ratios of $\delta^{34} \mathrm{~S}$ of $\mathrm{SO}_{4}^{2-}$ in groundwater samples ranged from -11.5 to 31.6 per mil (table 5, in back of report) and appear to reflect several processes and mixtures of sources. The $\delta^{34} \mathrm{~S}$ of $\mathrm{SO}_{4}^{2-}$ in water samples from most bedrock wells are much heavier and have higher $\mathrm{SO}_{4}^{2-}$ concentrations, as compared to water samples from wells screened in unconsolidated deposits, springs, and surface water.

Strontium ( $\mathrm{Sr}$ ) is a useful isotope for tracing water sources because the ${ }^{87} \mathrm{Sr} /{ }^{86} \mathrm{Sr}$ ratio does not fractionate during evaporation or precipitation and because $\mathrm{Sr}$ derived from any mineral will retain the same ratio in water (Bullen and Kendall, 1995). Sr in groundwater results from its interaction with aquifer material and should have a range of ${ }^{87} \mathrm{Sr} /{ }^{86} \mathrm{Sr}$ ratios similar to geologic material. Strontium concentrations are greater and ${ }^{87} \mathrm{Sr} /{ }^{86} \mathrm{Sr}$ ratios more depleted in groundwater samples from some bedrock wells (U1630, U1631, and U1647), as compared to other samples (table 5, in back of report), and likely reflect the isotopic signature from a different aquifer source and (or) the extent of water-rock interaction of this source.

The $\delta^{13} \mathrm{C}$ values for DIC in groundwater samples ranged from -23.5 to -8.17 per mil with a median of -14 per mil (table 5 , in back of report). The slightly heavier $\delta^{13} \mathrm{C}$ of DIC in water samples from bedrock wells (-13.1 per mil at U1628; table 5, in back of report) could be related to the weathering of 
calcite in carbonate rocks, which contain heavier $\delta^{13} \mathrm{C}$ values. Many of the bedrock well samples are at or near saturation with respect to calcite (table 3 , in back of report) and may indicate dissolution of calcite at some point along their flow paths. The $\delta^{13} \mathrm{C}$ of DIC in surface-water samples (median of -13.5 for all Lippman Lake and Rondout Reservoir samples) also could be enriched during summer months by algal blooms; the $\delta^{13} \mathrm{C}$ values for DIC in the Lippman Lake sample collected on July 2, 2009, was -8.17 per mil.

\section{Groundwater Age}

Samples were collected to estimate groundwater ages using the following tracers: ${ }^{3} \mathrm{H}, \mathrm{SF}_{6}$, and CFCs. Apparent groundwater age is defined as the time elapsed since recharge of a sampled parcel of water. Concentrations of ${ }^{3} \mathrm{H}$ were measured in several wells to determine whether the water was older than 1953 (prior to nuclear atmospheric weapons testing) or younger.

Dissolved gas concentrations were measured to estimate the temperature of groundwater at the time of recharge, because the solubility of atmospheric tracers varies as a function of temperature, and to calculate the amounts of excess air and $\mathrm{N}_{2}$ (table 4 , in back of report). Recharge temperatures estimated from $\mathrm{Ar}$ and $\mathrm{N}_{2}$ dissolved gas concentrations varied among wells. The ratio of these dissolved gases $\left(\mathrm{N}_{2}\right.$ and Ar) in water samples from several bedrock wells, including U1628, U1631, and U1630, indicate large amounts of excess air. Excess air consists of air trapped in pores that dissolves in groundwater, typically after a rapid rise in the water table, or some other source of atmospheric gases. Dissolved gas concentrations in all samples indicate that there was little or no excess $\mathrm{N}_{2}$, which can result from the reduction of $\mathrm{NO}_{3}^{-}$, contributing to excess air. The ratio of dissolved gases in samples from several wells and a spring also appeared to be altered by degassing. The degassing was possibly caused by the generation of $\mathrm{CH}_{4}$ and $\mathrm{H}_{2} \mathrm{~S}$ gas bubbles resulting from organic-matter decomposition or other microbial processes that preferentially remove $\mathrm{N}_{2}$, which is less soluble than Ar. As a result of these gas problems in the samples (as described in "age tracer notes" in table 4, in back of report), the recharge temperatures, excess air volumes, and age-tracer concentrations of several bedrock wells could not be determined with confidence. These bedrock wells include U1628, U1631, U1630, and U1647.

Dating groundwater with ${ }^{3} \mathrm{H}$ is qualitative at best, but can be useful in recognizing post-nuclear testing water, and can be used together with other tracers to estimate mixing of groundwater from various sources. Concentrations of ${ }^{3} \mathrm{H}$ in samples from springs or wells screened in the unconsolidated deposits ranged from less than 0.03 picoCuries per liter (pCi/L) in well U1637, which had an upward-flow gradient, to $60 \mathrm{pCi} / \mathrm{L}$ in well U1666, a basement spring sample collected on June 23, 2009 (table 4, in back of report). These ranges in values reflect, in part, the high seasonal and annual variations of ${ }^{3} \mathrm{H}$ observed in precipitation (Clark and Fritz,
1997). Concentrations of ${ }^{3} \mathrm{H}$ in samples from bedrock wells ranged from $<0.03$ to $60 \mathrm{pCi} / \mathrm{L}$. Samples from wells that had low ${ }^{3} \mathrm{H}$ concentrations $(<10 \mathrm{pCi} / \mathrm{L})$ could be current or have substantial components of old water that were recharged before 1953 . The low ${ }^{3} \mathrm{H}$ concentration $(<0.03 \mathrm{pCi} / \mathrm{L})$ in the groundwater sample from unconsolidated aquifer well U1637 indicates that the water likely was recharged before 1953. The sample from U1641 - the adjacent, deeper well screened in unconsolidated deposits - also had a low ${ }^{3} \mathrm{H}$ concentration $(1.1 \mathrm{pCi} / \mathrm{L})$ compared to other unconsolidated aquifer wells and is consistent with the upward-head gradient at that location, indicating that older groundwater is flowing upward from bedrock. The upper range value of $60 \mathrm{pCi} / \mathrm{L}$ in a sample from the well U1666 basement spring indicates that either the water was recharged during the ${ }^{3} \mathrm{H}$ peak in the early 1960 s or that the water was affected by ${ }^{3} \mathrm{H}$ contamination, possibly from a nearby landfill. The early 1960 s recharge date is unlikely, given the young apparent recharge years indicated by the age tracers $\mathrm{SF}_{6}$ CFC-11, CFC-12, and CFC-113, as discussed later in this section.

Results of the CFC and $\mathrm{SF}_{6}$ age tracers for samples from several of the wells screened in unconsolidated deposits and springs showed conflicting apparent ages and recharge years. The apparent $\mathrm{SF}_{6}$ ages generally were younger than those of $\mathrm{CFC}$ ages, apparently caused by the degradation of CFCs, which results in erroneously young apparent ages. The CFC11 and CFC-113 tracers are prone to degradation under reducing conditions. Other limitations of CFCs include problems with dating extremely young waters (Hunt and others, 2005), issues with mixing of waters of varying age (Goode, 1996; Bethke and Johnson, 2002; Weissman and others, 2002), and the leveling off or declining of atmospheric concentrations over time (Plummer and Busenberg, 1999). The $\mathrm{SF}_{6}$ ages of samples from wells screened in unconsolidated deposits and springs seemed more reasonable; recharge years of most springs or wells ranged from 2003.0 to 2009.5 and indicate short flow paths from the point of groundwater recharge. The exception is the sample from well U1641, which had an apparent $\mathrm{SF}_{6}$ recharge year of 1975-76. Adequate flow could not be obtained from nearby well U1637 to produce dissolved-gas or age-tracer samples, but the upward-flow gradient at this location is consistent with the older recharge year and a longer flow path.

CFC age-tracer samples also were collected from Lippman Lake and Rondout Reservoir because they could be important sources of groundwater in the study area. The presence of CFC-11, CFC-12, and CFC-113 in samples from both surface-water bodies showed degradation, which is common in northern temperate lakes owing to organic-rich sediments and anoxic conditions (Walker and others, 2007). Recharge temperatures were estimated for Lippman Lake effluent and Rondout Reservoir samples because dissolved gas samples were not collected at these sites. The water-sample temperature at the time of collection was used for recharge temperatures at Rondout Reservoir. At Lippman Lake, the mean annual air temperature $\left(10^{\circ} \mathrm{C}\right)$ was used for the sample 
collected on June 23, 2009; for the sample collected on December 22, 2009, the mean air temperature for the previous 2 months, November and December $\left(7^{\circ} \mathrm{C}\right)$, was used for the estimated recharge temperature because it was judged to be more representative of water in this shallow water body during this time of year (table 4, in back of report).

As discussed earlier in this section, most of the samples from bedrock wells had interference problems with dissolved gases, either because of excess air from trapped bubbles in recharge water or degassing from high concentrations of $\mathrm{H}_{2} \mathrm{~S}$ and $\mathrm{CH}_{4}$. Water samples from three wells, U1629, U1625, and U1645, did not appear to have these problems, at least enough to prevent apparent-age estimates. A sample from U1629, which is located near the RWB Tunnel, had an apparent "piston recharge" year of early 1950s, consistent with other chemistry that showed little or no similarity to the tunnel water chemistry. "Piston recharge" assumes that a tracer becomes incorporated in a parcel of water that moves from the recharge area with the mean velocity of groundwater. The CFC apparent-recharge year based on CFCs was similar to that based on $\mathrm{SF}_{6}$. Well U1625 was sampled on two occasions. The June 24, 2009 sample, collected during a period of nearby basement flooding, indicated consistency between the $\mathrm{SF}_{6}$ recharge year of 2003 and the CFC-12 apparent-recharge year of 2002.8. CFC-11 and CFC-113 are more prone to degradation under reducing conditions and likely are not as reliable in this sample. The degradation of these CFCs indicates that some component of reducing water contributes to the well. The later sample was collected on December 14, 2009, during a period of lower head pressure in the tunnel (Stumm and others, 2012), and the apparent $\mathrm{SF}_{6}$ recharge year of 2000.5 indicates a greater component of older water, apparently caused by a lower contribution of water from the RWB Tunnel and a greater contribution from ambient groundwater. The reducing properties of ambient water from bedrock also might have resulted in degradation of CFCs in the sample collected on December 14, 2009, at well U1625. A sample from U1645 had an $\mathrm{SF}_{6}$ apparent recharge year of 1970, but one or more of the CFCs was degraded and yielded older ages.

\section{Summary and Conclusions}

The U.S. Geological Survey and the New York City Department of Environmental Protection conducted a cooperative study to evaluate the water chemistry and potential effects of flooding in Wawarsing, N.Y. These data, together with hydrogeologic data, can be used to improve the understanding of source waters and groundwater-flow patterns and pathways and to help assess mixing of the different source waters in water samples.

Major-ion concentrations in water samples collected during the study show differences depending on the sample type, depth, and location. Water samples from most wells screened in unconsolidated deposits and springs had a greater percentage of calcium as compared to other cations than samples from bedrock wells. The exception was well U1625, which had high ratios of bicarbonate and calcium relative to other ions similar to samples from the unconsolidated aquifer wells and the surface-water samples. Samples from bedrock wells generally had relatively higher concentrations of sulfate $\left(\mathrm{SO}_{4}{ }^{2-}\right)$ as compared to other anions. Water samples from most wells screened in unconsolidated deposits and springs were greater in bicarbonate and carbonate than in $\mathrm{SO}_{4}{ }^{2-}$ and chloride, as compared to samples from bedrock wells. Differences in calcite and gypsum saturation indexes in water samples were evident among (1) most bedrock wells and wells screened in unconsolidated aquifer wells and (2) water samples collected from two bedrock wells during high head pressure and water samples collected during low head pressure of the RondoutWest Branch (RWB) Tunnel. Concentrations of trace constituents, including strontium (Sr), barium (Ba), arsenic (As), boron (B), lithium ( $\mathrm{Li})$, nickel $(\mathrm{Ni})$, and lead $(\mathrm{Pb})$, generally were higher in samples from bedrock wells than in samples from wells screened in unconsolidated deposits and in water from RWB Tunnel or in the lake at Lippman Park.

Nitrate $\left(\mathrm{NO}_{3}^{-}\right)$plus nitrite $\left(\mathrm{NO}_{2}^{-}\right)$concentrations ranged from less than minimum reporting levels (MRLs) in water samples with reducing redox characteristics to 0.88 milligram per liter $(\mathrm{mg} / \mathrm{L})$ as nitrogen $(\mathrm{N})$ for a domestic well in a residential area with onsite septic-tank drainfields (table 3, in back of report). Concentrations of $\mathrm{NO}_{2}^{-}$were less than the MRL of $0.008 \mathrm{mg} / \mathrm{L}$ in all but two samples; therefore, $\mathrm{NO}_{3}^{-}$plus $\mathrm{NO}_{2}{ }^{-}$ is referred to herein as " $\mathrm{NO}_{3}{ }^{-}$." The median concentration of $\mathrm{NO}_{3}{ }^{-}$for wells in the study area was less than $0.5 \mathrm{mg} / \mathrm{L}$ as N, and samples at more than one-half of the sites were below the reporting level of $0.04 \mathrm{mg} / \mathrm{L}$ as N. Urban septic-system leachate and lawn fertilizer are the major sources of $\mathrm{NO}_{3}{ }^{-}$in the study area and can affect shallow groundwater quality.

Dissolved gas concentrations were measured to estimate the temperature of groundwater at the time of recharge, because the solubility of atmospheric tracers varies as a function of temperature, and to calculate the amount of excess air and excess nitrogen $\left(\mathrm{N}_{2}\right)$. Recharge temperatures estimated from argon ( $\mathrm{Ar}$ ) and $\mathrm{N}_{2}$ dissolved gas concentrations varied among wells. Most of the samples from bedrock wells had interference problems with dissolved gases, either because of excess air from trapped bubbles in recharge water or degassing from high concentrations of hydrogen sulfide $\left(\mathrm{H}_{2} \mathrm{~S}\right)$ and methane $\left(\mathrm{CH}_{4}\right)$. The ratio of $\mathrm{N}_{2}$ and $\mathrm{Ar}$ in water samples from several bedrock wells, including U1628, U1631, and U1630, indicated large amounts of excess air and (or) degassing.

Age-tracer data provided useful information on pathways of the groundwater-flow system but were limited by inherent problems with dissolved gas data. Tritium concentrations in samples from springs or wells screened in unconsolidated deposits ranged from less than 0.03 picoCurie per liter $(\mathrm{pCi} / \mathrm{L})$ in an unconsolidated aquifer well with an upward-flow gradient to $60 \mathrm{pCi} / \mathrm{L}$ in a basement spring sample. Results of the chlorofluorocarbon (CFC) and sulfur hexafluoride $\left(\mathrm{SF}_{6}\right)$ age tracers for some of the wells screened in unconsolidated deposits and springs showed conflicting apparent ages and 
recharge years. The apparent $\mathrm{SF}_{6}$ ages generally were younger than those of CFC ages, apparently caused by the degradation of CFCs that resulted in erroneously young apparent ages. The $\mathrm{SF}_{6}$ ages of the wells screened in unconsolidated deposits and springs seemed more reasonable; recharge years of most springs or shallow wells ranged from 2003 to 2010 (current) and indicate short flow paths from the point of groundwater recharge. The exception is an apparent age of early to mid1970s for a sample from well U1641 that is screened in poorly permeable sediments and had an upward-flow gradient.

Water samples from three bedrock wells, U1629, U1625, and U1645, did not appear to have a problem with dissolved gases that prevented apparent-age estimates. A sample from U1629, which is located near the RWB Tunnel, had an apparent piston recharge date of early 1950 s, consistent with other chemistry that showed little or no similarity to the water chemistry in the tunnel. The apparent recharge year based on CFCs was similar to that of $\mathrm{SF}_{6}$. Well U1625 was sampled on two occasions. The sample collected June 24, 2009, during a period of nearby basement flooding, indicated consistency between the $\mathrm{SF}_{6}$ recharge year of 2003 and the CFC-12 apparent recharge year of 2002.8. CFC-11 and CFC-113 are more prone to degradation under reducing conditions and likely are not as reliable in this sample. The degradation of these CFCs indicates that some component of reducing water contributes to the well. The later sample was collected on December 14, 2009, during a period of lower head pressure in the tunnel (Stumm and others, 2012), and the apparent $\mathrm{SF}_{6}$ recharge year of 2000.5 indicates a greater component of older water, apparently caused by less contribution of water from the RWB Tunnel and greater contribution from ambient groundwater. A sample from U1645 had an $\mathrm{SF}_{6}$ apparent recharge year of 1970 .

Stable isotopes were analyzed to help determine different chemical sources that affect flooding and the amount of mixing of the waters. Differences in stable-isotope ratios among $\delta^{18} \mathrm{O},{ }^{2} \mathrm{H}, \delta^{34} \mathrm{~S}$ of $\mathrm{SO}_{4}{ }^{2-},{ }^{87} \mathrm{Sr} /{ }^{86} \mathrm{Sr}$, and $\delta^{13} \mathrm{C}$ of dissolved inorganic carbon (DIC) indicate potential for distinguishing water in Delaware-West Branch Tunnel from native groundwater. The $\delta^{18} \mathrm{O}$ and $\delta^{2} \mathrm{H}$ values in water from the RWB Tunnel vary seasonally as a result of evaporative concentration of the heavier isotopes, ${ }^{18} \mathrm{O}$ and ${ }^{2} \mathrm{H}$. Water samples collected during the warmer months showed distinct differences between water from the RWB Tunnel and water from bedrock wells. The $\delta^{34} \mathrm{~S}$ of $\mathrm{SO}_{4}^{2-}$ in water samples from most bedrock wells are much heavier and have higher $\mathrm{SO}_{4}^{2-}$ concentrations, as compared to water samples from wells screened in unconsolidated deposits, springs, and surface water. Strontium concentrations are greater and ${ }^{87} \mathrm{Sr} /{ }^{86} \mathrm{Sr}$ ratios are more depleted in groundwater samples from most bedrock wells, as compared to samples from surface-water sources, springs, and wells screened in unconsolidated deposits in the study area. The heavier $\delta^{13} \mathrm{C}$ of DIC in water samples from bedrock wells could be related to the weathering of calcite in carbonate rocks, which contain heavier $\delta^{13} \mathrm{C}$ values. Many of the bedrock well samples were at or near saturation with respect to calcite and may indicate dissolution of calcite at some point along their flow paths.

\section{References Cited}

Berkey, C.P., 1911, Geology of the New York City (Catskill) Aqueduct: New York Education Department Bulletin No. 489, New York State Museum Bulletin 146, 283 p.

Berkey, C.P., and Fluhr, T.W., 1936, The geologic formations of the New Rondout-West Branch Tunnel of the Delaware Aqueduct with generalized geological sections: New York City Board of Water Supply, 59 p.

Bethke, C.M., and Johnson, T.M., 2002, Ground water age: Ground Water, v. 40, no. 4, p. 337-339.

Bird, P.H., 1944, Crystal-lined cavity in Shawangunk Grit: Delaware Water Supply News, v. 6, no. 121, p. 563.

Bullen, T.D., and Kendall, Carol, 1995, Tracing of weathering reactions and water flowpaths-A multi-isotope approach, in McDonnell, J.J., and Kendall, Carol, eds., Isotope tracers in catchment hydrology: Elsevier, Amsterdam, 50 p.

Bullen, T.D., White, A.F., Blum, A.E., Harden, J.W., and Schulz, M.S., 1997, Chemical weathering of a soil chronosequence on granitoid alluvium-II, Mineralogic and isotopic constraints on the behavior of strontium: Geochimica et Cosmochimica Acta, v. 61, p. 291-306.

Bullister, J.L., 1984, Atmospheric chlorofluoromethanes as tracers of ocean circulation and mixing-Studies in the Greenland and Norwegian seas: San Diego, University of California, Ph.D. dissertation, $172 \mathrm{p}$.

Bullister, J.L., and Weiss, R.F., 1988, Determination of CCl3F and CClF2 in seawater and air: Deep-Sea Research, v. 35, no. 5 , p. 839-854.

Busenberg, Eurybiades, and Plummer, L.N., 1992, Use of chlorofluorocarbons $\left(\mathrm{CCl}_{3} \mathrm{~F}\right.$ and $\left.\mathrm{CCl}_{2} \mathrm{~F}_{2}\right)$ as hydrologic tracers and age-dating tools-The alluvium and terrace system of central Oklahoma: Water Resources Research, v. 28 , no. 9 , p. 2257-2283.

Busenberg, Eurybiades, and Plummer, L.N., 2000, Dating young groundwater with sulfur hexafluoride-Natural and anthropogenic sources of sulfur hexafluoride: Water Resources Research, v. 36, p. 3011-3030.

Busenberg, Eurybiades, Plummer, L.N., Bartholomay, R.C., and Wayland, J.E., 1998, Chlorofluorocarbons, sulfur hexafluoride, and dissolved permanent gases in groundwater from selected sites in and near the Idaho National Engineering and Environmental Laboratory, Idaho, 199497: U.S. Geological Survey Open-File Report 98-274, 72 p. (DOE/ID-22151).

Cadwell, D.H., 1989, Surficial geologic map of New York: Lower Hudson Sheet, New York State Museum and Science Service, Map and Chart Series No. 40, 5 sheets, 1:250,000. 
Carmody, R.W., Plummer, L.N., Busenberg, Eurybiades, and Coplen, T.B., 1998, Methods for collection of dissolved sulfate and sulfide and analysis of their sulfur isotopic composition: U.S. Geological Survey Open-File Report 97-234, $91 \mathrm{p}$.

Chapelle, F.H., Bradley, P.M., Thomas, M.A., and McMahon, P.B., 2009, Distinguishing iron-reducing from sulfatereducing conditions: Ground Water, v. 47, no. 2, MarchApril 2009, p. 300-305.

Clark, I.D., and Fritz, Peter, 1997, Environmental isotopes in hydrogeology: New York, CRC Press LLC, 328 p.

Coplen T.B., and Kendall, Carol, 2000, Stable hydrogen and oxygen isotope ratios for selected sites of the U.S. Geological Survey's NASQAN and benchmark surfacewater networks: U.S. Geological Survey Open-File Report 00-160, 409 p. (Available at http://pubs.usgs.gov/of/2000/ ofro0-160/.)

Coplen, T.B., Wildman, J.D., and Chen, Julie, 1991, Improvements in the gaseous hydrogen-water equilibration technique for hydrogen isotope ratio analysis: Analytical Chemistry, v. 63, p. 910-912.

Dibbell, H.A., 1944, Delaware Aqueduct, Rondout-West Branch Tunnel record drawing: New York City Bureau of Water Supply, 96 sheets.

DiNapoli, T.D., 2007, New York City Department of Environmental Protection Delaware Aqueduct System: Water Leak Detection and Repair Program: Office of the New York State Comptroller, Division of State Government Accountability, Report 2005-N-7, 19 p.

Effler, S.W., Matthews, C.M., and Matthews, D.A., 2001, Patterns of gross deposition in reservoirs enriched in inorganic tripton: Canadian Journal of Fisheries and Aquatic Sciences, v. 58, p. 2177-2188.

Effler, S.W., and O'Donnell, D.M., 2001, Resolution of spatial patterns in three reservoirs with rapid profiling instrumentation: Hydrobiologia, v. 450, p. 197-208.

Epstein, Samuel, and Mayeda, Toshiko, 1953, Variation of $18 \mathrm{O}$ content of waters from natural sources: Geochimica et Cosmochimica Acta, v. 4, no. 5, p. 213-224.

Fluhr, T.W., 1950, Descriptions of core borings in the upper Delaware River basin: New York State Geological Survey Open-File No. 6qF615, 10 p.
Fluhr, T.W., 1953, Geology of New York City's water supply system-A progress report: Municipal Engineers Journal, v. 39 , 4th quarterly issue, p. 125-145.

Frimpter, M.H., 1970, Ground-water basic data for Orange and Ulster Counties, New York: New York State Conservation Department Bulletin 65, 93 p.

Frimpter, M.H., 1972, Ground-water resources of Orange and Ulster Counties, New York: U.S. Geological Survey Water Supply Paper 1985, 80 p.

Goode, D.J., 1996, Direct simulation of groundwater age: Water Resources Research, v. 32, no. 2, p. 289-296.

HACH Company, 2002, DR/2400 spectrophotometer procedures manual: Loveland, Colo., 450 p.

Heusser, G., 1976, Legend and history and minerals of the Ellenville mines: Ellenville, N.Y., privately published, 26 p.

Hunt, R.J., Coplen, T.B., Haas, N.L., Saad, D.A., and Borchardt, M.A., 2005, Investigating surface water-well interaction using stable isotope ratios of water: Journal of Hydrology, v. 302, no. 1-4, p. 154-172.

Kargbo, D.M., Wilhelm, R.G., and Campbell, D.J., 2010, Natural gas plays in the Marcellus Shale - Challenges and potential opportunities: Environmental Science \& Technology, v. 44, p. 5679-5684.

Kendall, Carol, and Coplen, T.B., 2000, Distribution of oxygen-18 and deuterium in river waters across the United States: Hydrological Processes, v. 15, no. 7, p. 1363-1393.

Kesler, S.E., Friedman, G.M., and Krstic, Dragan, 1997, Mississippi valley-type mineralization in the Silurian paleoaquifer, central Appalachians: Chemical Geology, v. 138 , p. $127-134$.

Koterba, M.T., Wilde, F.D., and Lapham, W.W., 1995, Groundwater data-collection protocols and procedures for the National Water-Quality Assessment ProgramCollection and documentation of water-quality samples and related data: U.S. Geological Survey Open-File Report 95-399, $113 \mathrm{p}$.

McMahon, P.B., and Chapelle, F.H., 2007, Redox processes and water quality of selected principal aquifer systems: Ground Water, v. 46, no. 2, p. 259-271. 
Merguerian, Charles, 2000, History and geology of the NYC Aqueduct system - A history of the NYC water supply system: Lecture at the Long Island Geologists Dinner Meeting, 04 October 2000, 7 p. (Available at http://people. hofstra.edu/charles_merguerian/ForTeachers/NYC_Water Supply/NYCWaterSupply.htm.)

National Oceanic and Atmospheric Administration, 2010, Monthly and annual precipitation at Central Park, Manhattan, New York, accessed August 11, 2011, at http://www.erh.noaa.gov/okx/climate_cms.html.

New York City Department of Environmental Protection, 2010, History of New York City's water supply system, accessed August 11, 2011, at http://www.nyc.gov/html/dep/ $\mathrm{html} /$ drinking_water/history.shtml.

New York State Department of Health, 1982, New York State atlas of community water system sources: Division of Environmental Protection, Bureau of Public Supply Protection, $79 \mathrm{p}$.

Osborn, S.G., Vengosh, Avner, Warner, N.R., and Jackson, R.B., 2011, Methane contamination of drinking water accompanying gas-well drilling and hydraulic fracturing: PNAS, v. 108 , no. 20 , p. $8172-8176$. (Available at http://www.pnas.org/content/108/20/8172.)

Owens, E.M., 1998, Identification and analysis of hydrodynamic and transport characteristics of Cannonsville Reservoir: Lake and Reservoir Management, v. 14, no. 2-3, p. 152-161.

Piper, A.M., 1944, A graphical procedure in the geochemical interpretation of water-analyses: American Geophysical Union Transactions, v. 25, p. 914-923.

Plummer, L.N., and Busenberg, Eurybiades, 1999, Chlorofluorocarbons, tools for dating and tracing young groundwater, in Cook, P.G., and Herczeg, A., eds., Environmental tracers in subsurface hydrology, chap. 15: Boston, Kluwer Academic Press, p. 441-478.

Randall, A.D., 1996, Mean annual runoff, precipitation, and evapotranspiration in the glaciated northeastern United States, 1951-80: U.S. Geological Survey Open-File Report 96-395, 2 pls.

Reynolds, R.J., 2007, Hydrogeologic appraisal of the valleyfill aquifer in the Port Jervis Trough, Sullivan and Ulster Counties, New York: U.S. Geological Survey Scientific Investigations Map 2960, 5 sheets, online only, at http://pubs.usgs.gov/sim/2007/2960/.
Schlosser, Peter, Stute, Martin, Sonntag, C., and Munnich, K.O., 1989, Tritiogenic 3He in shallow groundwater: Earth Planetary Science Letters, v. 94, p. 245-256.

Stumm, Frederick, Chu, Anthony, Como, M.D., and Noll, M.L., 2012, Preliminary analysis of the hydrologic effects of temporary shutdowns of the Rondout-West Branch Water Tunnel on the groundwater-flow system in Wawarsing, New York: U.S. Geological Survey Scientific Investigations Report 2012-5015, 48 p. (Available at http://pubs.usgs.gov/ $\operatorname{sir} / 2012 / 5015 /$.)

U.S. Census Bureau, 2010, New York: Department of Labor, accessed March 27, 2012, at http://factfinder2. census.gov/faces/tableservices/jsf/pages/productview. $\mathrm{xhtml}$ ?pid=DEC_10_SF1_P1\&prodType=table.

U.S. Environmental Protection Agency, 2006a, Title 40Protection of Environment, Chapter I-Environmental Protection Agency, Part 141-National primary drinking water regulations, accessed October 20, 2007, at http://www.access.gpo.gov/nara/cfr/ waisidx_02/40cfr141_02.html.

U.S. Environmental Protection Agency, 2006b, Title 40Protection of Environment, Chapter I-Environmental Protection Agency, Part 143-National secondary drinking water regulations, accessed on October 20, 2007, at http://www.access.gpo.gov/nara/cfr/ waisidx_02/40cfr143_02.html.

Walker, J.F., Saad, D.A., and Hunt, R.J., 2007, Dynamics of CFCs in northern temperate lakes and adjacent groundwater: Water Resources Research, v. 43, 12 p.

Weissman, G.S., Zhang, Y., LaBolle, E.M., and Fogg, G.E., 2002, Dispersion of groundwater age in an alluvial aquifer system: Water Resources Research, v. 38, no. 10, p. 16-1 to 16-8.

Wilbur, J.S., Mutschler, F.E., Friedman, J.D., and Zartman, R.E., 1990, New chemical, isotopic, and fluid inclusion data from zinc-lead-copper veins, Shawangunk Mountains, New York: Economic Geology, v. 85, p. 182-196.

Williams, J.H., and Eckhardt, D.A., 1987, Groundwater resources of the Berwick-Bloomsburg-Danville area, eastcentral Pennsylvania: Pennsylvania Geological Survey Water Resources Report 68, 89 p. 
THIS PAGE INTENTIONALLY LEFT BLANK 
Tables 3-5 
Table 3. General chemical characteristics, concentrations of major elements and nutrients, saturation indexes, and percent charge balance error in surfaceBranch Tunnel in Lackawack, Ulster County, New York, 2009-11.

$[\mu \mathrm{S} / \mathrm{cm}$, microsiemens per centimeter at 25 degrees Celsius; SI, saturation index; concentrations in milligrams per literunless indicated otherwise; Ca, calcium; Mg, magne$\mathrm{N}$, nitrogen; $\mathrm{PO}_{4}^{3-}$, orthophosphate; --, not measured; NA, not applicable; <, less than; E, estimated value below minimum reporting level]

\begin{tabular}{|c|c|c|c|c|c|c|c|c|c|c|c|c|c|c|c|c|c|c|}
\hline Well identifier & Date & $\begin{array}{c}\text { Sam- } \\
\text { ple } \\
\text { time }\end{array}$ & $\begin{array}{c}\text { Tem- } \\
\text { perature, } \\
\text { water } \\
\text { (degrees } \\
\text { Celsius) } \\
\end{array}$ & $\mathrm{pH}$ & $\begin{array}{c}\text { Specific } \\
\text { conduc- } \\
\text { tance } \\
(\mu \mathrm{S} / \mathrm{cm})\end{array}$ & $\begin{array}{c}\text { Depth } \\
\text { of well } \\
\text { (feet be- } \\
\text { low land } \\
\text { surface) }\end{array}$ & $\begin{array}{l}\text { Dis- } \\
\text { solved } \\
\text { solids }\end{array}$ & $\begin{array}{c}\text { Hard- } \\
\text { ness, } \\
\text { as } \\
\mathrm{CaCO}_{3}\end{array}$ & $\mathrm{Ca}$ & $\mathbf{M g}$ & K & $\mathrm{Na}$ & $\begin{array}{l}\text { Alka- } \\
\text { linity }\end{array}$ & $\mathrm{HCO}_{3}^{-}$ & $\mathrm{CO}_{3}{ }^{2-}$ & $\mathrm{Cl}^{-}$ & $\mathrm{Br}$ & $\begin{array}{l}\text { Cl.Br } \\
\text { mass } \\
\text { ratio }\end{array}$ \\
\hline U1626 & $12 / 15 / 2009$ & 1500 & 8.8 & 6.3 & 94 & 10 & 67 & 43 & 14 & 1.9 & 0.43 & 2.3 & 41 & 50 & $<0.1$ & 1.2 & 0.01 & 120 \\
\hline U1627 & $6 / 23 / 2009$ & 1200 & 15.8 & 6.8 & 499 & 15 & 338 & 160 & 56 & 6.0 & 1.35 & 52 & -- & 160 & $<0.1$ & 96 & 0.04 & 2,400 \\
\hline U1627 & 4/1/2010 & 0900 & 6.8 & 6.9 & 551 & 15 & 281 & 130 & 45 & 4.5 & 0.94 & 53 & 120 & 140 & $<0.1$ & 86 & 0.03 & 2,867 \\
\hline U1637 & $8 / 31 / 2010$ & 1400 & 15.6 & 7.8 & 226 & 26.5 & 135 & 104 & 32 & 5.6 & 1.25 & 4.2 & 90 & 110 & $<0.1$ & 1.6 & 0.011 & 145 \\
\hline U1641 & $4 / 20 / 2010$ & 1300 & 11.6 & 8.0 & 224 & 117 & 137 & 110 & 34 & 6.1 & 0.94 & 3.8 & 60 & 73 & $<0.1$ & 1.9 & 0.01 & 190 \\
\hline U1641 & $4 / 20 / 2010$ & 1301 & -- & 8.0 & 224 & 117 & 140 & 110 & 33 & 6.0 & 0.86 & 3.8 & 60 & 73 & $<0.1$ & 1.9 & 0.01 & 190 \\
\hline U1663 & $8 / 31 / 2010$ & 1400 & 14.5 & 8.2 & 286 & 47 & 167 & 79 & 23 & 5.1 & 1.9 & 32 & 130 & 160 & $<0.1$ & 9.0 & 0.065 & 138 \\
\hline U1673 & $11 / 30 / 2011$ & 1200 & 11.6 & 7.7 & 345 & 180 & 188 & 160 & 50 & 9.3 & 0.68 & 8.4 & 120 & 150 & $<0.1$ & 21 & 0.02 & 1,050 \\
\hline U1670 & $11 / 30 / 2011$ & 1000 & 12.2 & 8.0 & 350 & 180 & 197 & 160 & 49 & 8.3 & 0.77 & 12 & 120 & 140 & $<0.1$ & 30 & 0.02 & 1,500 \\
\hline U1632 & $9 / 14 / 2009$ & 1730 & 11.3 & 6.2 & 105 & NA & 54 & 38 & 12 & 2.1 & 0.43 & 1.7 & 37 & 46 & $<0.1$ & 1.1 & 0.01 & 110 \\
\hline U1633 & 9/15/2009 & 1200 & 16.1 & 6.3 & 85 & NA & 43 & 22 & 6.7 & 1.4 & 0.96 & 1.2 & 22 & 27 & $<0.1$ & 1.1 & 0.01 & 110 \\
\hline U1667 & $9 / 15 / 2009$ & 1400 & 13.4 & 6.9 & 66 & NA & 41 & 23 & 6.8 & 1.5 & 0.69 & 1.5 & 16 & 21 & $<0.1$ & 1.1 & 0.01 & 110 \\
\hline U1668 & $7 / 1 / 2009$ & 1300 & 14.8 & 6.9 & 78 & NA & 53 & 29 & 8.3 & 2.1 & 0.47 & 2.0 & 22 & 28 & $<0.1$ & 1.4 & 0.01 & 140 \\
\hline U1666 & $6 / 23 / 2009$ & 1400 & 13.6 & 6.7 & 284 & NA & 195 & 160 & 55 & 5.0 & 1.6 & 7.3 & 150 & 180 & $<0.1$ & 7.3 & 0.01 & 730 \\
\hline U1666 & $3 / 31 / 2010$ & 1600 & 7.5 & 6.8 & 332 & NA & 189 & 150 & 54 & 4.7 & 1.3 & 4.5 & 150 & 180 & $<0.1$ & 6.2 & 0.01 & 620 \\
\hline U1665 & $3 / 31 / 2010$ & 1200 & 6.4 & 6.0 & 60 & NA & 46 & 18 & 5.8 & 0.92 & 1.2 & 2.0 & 13 & 16 & $<0.1$ & 4.1 & 0.01 & 410 \\
\hline $\begin{array}{l}\text { Lippman Lake } \\
\text { effluent }\end{array}$ & $6 / 24 / 2009$ & 1330 & -- & -- & -- & NA & -- & -- & -- & -- & -- & -- & -- & -- & -- & -- & -- & -- \\
\hline $\begin{array}{l}\text { Lippman Lake } \\
\text { effluent }\end{array}$ & $7 / 2 / 2009$ & 1300 & 22.7 & 7.6 & 52 & NA & 53 & 41 & 13 & 2.4 & 0.50 & 2.3 & 36 & 43 & $<0.1$ & 1.9 & 0.01 & 190 \\
\hline $\begin{array}{l}\text { Lippman Lake } \\
\text { effluent }\end{array}$ & 9/1/2009 & 1230 & -- & -- & -- & NA & -- & -- & -- & -- & -- & -- & -- & -- & -- & -- & -- & -- \\
\hline $\begin{array}{l}\text { Lippman Lake } \\
\text { effluent }\end{array}$ & 9/16/2009 & 1300 & 21.2 & 7.3 & 217 & NA & 157 & 120 & 38 & 6.4 & 0.90 & 5.7 & 110 & 140 & 1 & 7.7 & 0.04 & 193 \\
\hline $\begin{array}{l}\text { Lippman Lake } \\
\text { effluent }\end{array}$ & $10 / 13 / 2009$ & 1515 & 13.8 & 7.4 & 231 & NA & -- & -- & -- & -- & -- & -- & -- & -- & $<0.1$ & -- & -- & -- \\
\hline $\begin{array}{l}\text { Lippman Lake } \\
\text { effluent }\end{array}$ & $12 / 15 / 2009$ & 1000 & 0.8 & 5.5 & 86 & NA & 60 & 32 & 9.3 & 2.2 & 0.37 & 2.7 & 29 & 35 & $<0.1$ & 2.2 & 0.01 & 220 \\
\hline $\begin{array}{l}\text { Lippman Lake } \\
\text { effluent }\end{array}$ & $4 / 1 / 2010$ & 1200 & 11.2 & 7.2 & 97 & NA & 65 & 39 & 12 & 2.2 & 0.42 & 2.4 & 36 & 44 & $<0.1$ & 2.7 & 0.01 & 270 \\
\hline 01366400 & $6 / 23 / 2009$ & 0930 & 10.3 & 6.4 & 60 & NA & 36 & 14 & 4 & 0.95 & 0.43 & 4.2 & 17 & 21 & $<0.1$ & 6.9 & 0.01 & 690 \\
\hline 01366400 & 9/1/2009 & 1030 & 15.4 & 6.2 & 45 & NA & 26 & 13 & 3.8 & 0.82 & 0.44 & 3.5 & 7.0 & 9.0 & $<0.1$ & 5.7 & 0.01 & 570 \\
\hline 01366400 & $10 / 13 / 2009$ & 1420 & 15.9 & 7.4 & 50 & NA & -- & -- & -- & -- & -- & -- & -- & -- & -- & -- & -- & -- \\
\hline 01366400 & $10 / 13 / 2009$ & 1425 & -- & -- & -- & NA & -- & -- & -- & -- & -- & -- & -- & -- & -- & -- & -- & -- \\
\hline 01366400 & $12 / 22 / 2009$ & 1110 & 6.7 & 7.2 & 53 & NA & 38 & 15 & 4.2 & 0.98 & 0.51 & 3.7 & 12 & 14 & $<0.1$ & 5.8 & 0.01 & 580 \\
\hline 01366400 & 4/1/2010 & 1000 & 5.4 & 7.1 & 51 & NA & 37 & 12 & 3.6 & 0.82 & 0.49 & 3.4 & 10 & 12 & $<0.1$ & 6.0 & 0.01 & 600 \\
\hline U1625 & $6 / 24 / 2009$ & 1100 & 11 & 7.5 & 134 & 275 & 84 & 63 & 20 & 2.8 & 0.65 & 5.5 & 57 & 70 & 0.1 & 7.5 & 0.02 & 375 \\
\hline U1625 & $12 / 14 / 2009$ & 1000 & 10.8 & 7.2 & 413 & 275 & 306 & 250 & 75 & 14 & 1.1 & 10 & 210 & 260 & $<0.1$ & 9.3 & 0.04 & 233 \\
\hline U1625 & 4/7/2011 & 1900 & -- & 7.6 & 109 & 275 & 63 & -- & 12 & 1.7 & 0.59 & 5.2 & 30 & 37 & $<0.1$ & 7.3 & $<.01$ & 1,450 \\
\hline U1629 & $6 / 24 / 2009$ & 0800 & 11.8 & 7.8 & 780 & 118 & 480 & 200 & 61 & 11 & 1.0 & 87 & 160 & 190 & 0.4 & 150 & 1.4 & 107 \\
\hline U1629 & 4/7/2011 & 1100 & -- & 7.0 & 370 & 118 & 260 & -- & 64 & 10 & 1.0 & 18 & 160 & 190 & -- & 40 & 0.32 & 125 \\
\hline U1629 & 4/7/2011 & 0900 & -- & 7.3 & 370 & 118 & 240 & -- & 64 & 10 & 0.96 & 9.1 & 160 & 200 & -- & 19 & 0.11 & 173 \\
\hline U1628 & $7 / 2 / 2009$ & 1000 & 12.8 & 8.1 & 409 & 200 & 320 & 190 & 44 & 20 & 1.0 & 23 & 66 & 80 & 0.4 & 20 & 0.15 & 133 \\
\hline U1630 & $9 / 15 / 2009$ & 1700 & 12.8 & 7.9 & 797 & NA & 580 & 290 & 65 & 31 & 1.5 & 48 & 8 & 9.8 & $<0.1$ & 45 & 0.45 & 100 \\
\hline U1631 & $9 / 16 / 2009$ & 1000 & 12.8 & 7.6 & 1,170 & NA & 930 & 540 & 150 & 37 & 2.3 & 46 & 96 & 120 & $<0.1$ & 58 & 0.53 & 109 \\
\hline U1631 & $9 / 16 / 2009$ & 1001 & 12.8 & 7.6 & 1,170 & NA & 920 & 540 & 150 & 37 & 2.3 & 46 & 96 & 120 & $<0.1$ & 57 & 0.54 & 106 \\
\hline U1631 & $12 / 14 / 2009$ & 1630 & 11.5 & 8.0 & 905 & NA & 850 & 500 & 130 & 36 & 2.2 & 42 & 95 & 120 & $<0.1$ & 54 & 0.52 & 104 \\
\hline U1647 & $4 / 21 / 2010$ & 1300 & 15.8 & 7.9 & 1,640 & NA & 1,100 & 460 & 110 & 39 & 5.4 & 170 & 100 & 130 & $<0.1$ & 250 & 2.2 & 114 \\
\hline U7017 & 9/20/2011 & 1200 & 12.1 & 6.9 & 236 & NA & 140 & 36 & 10 & 2.4 & 1.7 & 37 & 99 & 120 & $<0.1$ & 18 & 0.13 & 138 \\
\hline U3772 & 9/20/2011 & 1200 & 11.6 & 6.8 & 232 & NA & 140 & 49 & 15 & 2.3 & 2.3 & 30 & 120 & 140 & $<0.1$ & 1.7 & $<0.01$ & 680 \\
\hline U1645 & $9 / 21 / 2011$ & 1200 & 12.9 & 7.2 & 443 & NA & 20 & 200 & 53 & 16 & 1.1 & 11 & 170 & 210 & $<0.1$ & 7.6 & 0.036 & 210 \\
\hline U1644 & 9/21/2011 & 1200 & 14.3 & 7.8 & 1,060 & NA & 550 & 200 & 46 & 20 & 1.2 & 130 & 160 & 190 & $<0.1$ & 210 & 1.7 & 120 \\
\hline
\end{tabular}


water and groundwater samples from a lake, springs, and wells in the Wawarsing study area, and for the Rondout Reservoir at the influent to the Rondout-West sium; K, potassium; $\mathrm{Na}$, sodium; $\mathrm{HCO}_{3}^{-}$, bicarbonate; $\mathrm{Cl}^{-}$, chloride; $\mathrm{Br}-$, bromide; $\mathrm{F}$, fluoride; $\mathrm{SiO}_{2}$, silica; $\mathrm{SO}_{4}{ }^{2-}$, sulfate; $\mathrm{NH}_{4}^{+}$, ammonia; $\mathrm{NO}_{3}^{-}$, nitrate; $\mathrm{NO}_{2}^{-}$, nitrite;

\begin{tabular}{|c|c|c|c|c|c|c|c|c|c|c|c|c|c|c|c|c|}
\hline$F^{-}$ & $\mathrm{SiO}_{2}$ & $\mathrm{SO}_{4}{ }^{2-}$ & $\mathrm{NH}_{4}^{+}$ & $\begin{array}{l}\mathrm{NO}_{3}^{-} \\
\text {plus } \\
\mathrm{NO}_{2}^{-} \\
\text {as N }\end{array}$ & $\begin{array}{l}\mathrm{NO}_{2}^{-} \\
\text {as } \mathbf{N}\end{array}$ & $\begin{array}{c}\text { Ortho- } \\
\mathrm{PO}_{4}^{3-} \\
\text { as } \mathrm{P}\end{array}$ & Total N & Water type & $\underset{\left[\mathrm{Ca}^{+2}\right]}{\log }$ & $\underset{\left[\mathrm{Mg}^{+2}\right]}{\log }$ & $\begin{array}{c}\text { SI } \\
\text { (Calcite) }\end{array}$ & $\begin{array}{c}\text { SI } \\
\text { (Dolo- } \\
\text { mite) }\end{array}$ & $\begin{array}{c}\text { SI } \\
\text { (Gypsum) }\end{array}$ & $\begin{array}{c}\text { SI } \\
\text { (Fluorite) }\end{array}$ & $\begin{array}{c}\text { SI } \\
\text { (Quartz) }\end{array}$ & $\begin{array}{c}\text { Charge } \\
\text { balance } \\
\text { error } \\
\text { (per- } \\
\text { cent) }\end{array}$ \\
\hline$<.08$ & 9.4 & 8.7 & $<.020$ & 0.14 & $<.002$ & E.005 & 0.21 & $\mathrm{Ca}-\mathrm{HCO}_{3}$ & -3.5275 & -4.1936 & -2.4306 & -5.6473 & -3.073 & -3.5058 & 0.4295 & -3.2 \\
\hline E.05 & 5.2 & 14 & $<.020$ & 0.51 & $<.002$ & 0.031 & 0.60 & $\mathrm{Ca}-\mathrm{Na}-\mathrm{Cl}-\mathrm{HCO}_{3}$ & -3.0207 & -3.7667 & -0.8423 & -2.4281 & -2.4732 & -3.5589 & 0.0565 & -0.21 \\
\hline E.06 & 4.4 & 17 & $<.020$ & 0.71 & $<.002$ & 0.024 & 0.80 & $\mathrm{Na}-\mathrm{Ca}-\mathrm{Cl}-\mathrm{HCO}_{3}$ & -3.1021 & -3.8803 & -1.0107 & -2.9587 & -2.4423 & -3.3503 & 0.1292 & -1.7 \\
\hline 0.135 & 2.5 & 21 & 0.039 & $<0.04$ & $<0.002$ & 0.016 & $<.10$ & $\mathrm{Ca}-\mathrm{HCO}_{3}$ & -3.2221 & -3.7646 & -0.1996 & -0.9424 & -2.4445 & -2.8685 & -0.2635 & 0.12 \\
\hline 0.1 & 12 & 27 & 0.033 & $<0.04$ & $<.002$ & 0.013 & $<.10$ & $\mathrm{Ca}-\mathrm{Mg}-\mathrm{HCO}_{3}-\mathrm{SO}_{4}$ & -3.2025 & -3.7301 & -1.0795 & -2.6212 & -2.331 & -3.169 & 0.3483 & 14 \\
\hline 0.1 & 12 & 27 & 0.032 & $<0.04$ & $<.002$ & 0.012 & $<.10$ & -- & -2.7452 & -3.1179 & -1.0795 & -2.6212 & -0.8018 & -2.2993 & 0.5134 & 13 \\
\hline 0.44 & 1.6 & 3.4 & 0.092 & $<0.04$ & $<0.002$ & 0.02 & $<.10$ & $\mathrm{Na}-\mathrm{Ca}-\mathrm{HCO}_{3}$ & -3.3642 & -3.8067 & 0.2152 & -0.0306 & -3.3739 & -1.9723 & -0.43 & 0.12 \\
\hline$<.04$ & 8.6 & 25 & 0.013 & $<0.04$ & $<.001$ & 0.006 & $<.05$ & $\mathrm{Ca}-\mathrm{HCO}_{3}-\mathrm{Cl}$ & -3.0528 & -3.5639 & -0.2499 & -0.0689 & -2.2404 & -4.9295 & 0.3296 & -1.1 \\
\hline 0.06 & 8.6 & 20 & 0.018 & $<0.04$ & $<.001$ & 0.006 & $<.05$ & $\mathrm{Ca}-\mathrm{Mg}-\mathrm{HCO}_{3}$ & -3.0567 & -3.6092 & -0.0889 & -0.7896 & -2.3377 & -3.3666 & 0.3414 & -1.5 \\
\hline$<.08$ & 7.1 & 14.2 & $<.020$ & E.03 & $<.002$ & 0.020 & $<.10$ & $\mathrm{Ca}-\mathrm{HCO}_{3}-\mathrm{SO}_{4}$ & -3.6176 & -4.146 & -2.6175 & -5.837 & -2.9528 & -3.6333 & 0.2627 & -13 \\
\hline$<.08$ & 7.7 & 11.0 & $<.020$ & 0.04 & $<.002$ & 0.013 & 0.12 & $\mathrm{Ca}-\mathrm{Zn}-\mathrm{HCO}_{3}-\mathrm{SO}_{4}$ & -3.8477 & -4.3262 & -2.9039 & -6.2791 & -3.2865 & -3.9474 & 0.2222 & -15 \\
\hline$<.08$ & 8.3 & 12.6 & $<.020$ & $<0.04$ & $<.002$ & 0.024 & E.08 & $\mathrm{Ca}-\mathrm{Mg}-\mathrm{HCO}_{3}-\mathrm{SO}_{4}$ & -3.8373 & -4.2704 & -2.4642 & -5.3985 & -3.2048 & -3.8786 & 0.2993 & -6.5 \\
\hline E. 04 & 8.2 & 11.4 & E.014 & E.02 & $<.002$ & 0.026 & 0.19 & $\mathrm{Ca}-\mathrm{Mg}-\mathrm{HCO}_{3}-\mathrm{SO}_{4}$ & -3.7575 & -4.1308 & -2.2168 & -4.8205 & -3.1787 & -4.4212 & 0.2729 & -3.8 \\
\hline$<.08$ & 6.0 & 13.1 & $<.020$ & 0.16 & $<.002$ & 0.042 & 0.33 & $\mathrm{Ca}-\mathrm{HCO}_{3}$ & -3.0073 & -3.8304 & -0.8851 & -2.6269 & -2.4753 & -3.0961 & 0.1585 & -0.2 \\
\hline E. 05 & 4.7 & 13.9 & $<.020$ & 0.48 & $<.002$ & 0.041 & 0.57 & $\mathrm{Ca}-\mathrm{HCO}_{3}$ & -3.0086 & -3.8475 & -0.8976 & -2.7793 & -2.4337 & -3.4084 & 0.1498 & -1.6 \\
\hline$<.08$ & 4.6 & 6.41 & 0.027 & 0.35 & E.001 & 0.026 & 0.45 & $\mathrm{Ca}-\mathrm{HCO}_{3}-\mathrm{SO}_{4}-\mathrm{Cl}$ & -3.8997 & -4.4761 & -3.6296 & -8.0028 & -3.5388 & -3.9239 & 0.1557 & -5.4 \\
\hline-- & -- & -- & -- & -- & -- & -- & -- & -- & -- & -- & -- & -- & -- & -- & -- & -- \\
\hline E.04 & 4.7 & 5.22 & $<.020$ & $<0.04$ & $<.002$ & E.007 & 0.28 & $\mathrm{Ca}-\mathrm{Mg}-\mathrm{HCO}_{3}$ & -3.5763 & -4.0878 & -1.0385 & -2.4867 & -3.3565 & -4.3451 & -0.0934 & 4.0 \\
\hline-- & -- & -- & -- & -- & -- & -- & -- & -- & -- & -- & -- & -- & -- & -- & -- & -- \\
\hline 0.12 & 5.4 & 5.87 & $<.020$ & $<0.04$ & $<.002$ & E.004 & 0.25 & $\mathrm{Ca}-\mathrm{HCO}_{3}$ & -3.1497 & -3.7022 & -0.4377 & -1.346 & -2.9531 & -2.9777 & -0.0091 & 1.3 \\
\hline-- & -- & -- & -- & -- & -- & -- & -- & -- & -- & -- & -- & -- & -- & -- & -- & -- \\
\hline$<.08$ & 7.5 & 9.64 & $<.020$ & E.02 & E.001 & E.004 & 0.17 & $\mathrm{Ca}-\mathrm{Mg}-\mathrm{HCO}_{3}-\mathrm{SO}_{4}$ & -3.7075 & -4.1121 & -3.6966 & -8.0853 & -3.1722 & -3.6651 & 0.4671 & -4.4 \\
\hline E.04 & 4.8 & 7.10 & $<.020$ & $<0.04$ & $<.002$ & E.004 & 0.1 & $\mathrm{Ca}-\mathrm{HCO}_{3}$ & -3.5962 & -4.119 & -1.6173 & -3.833 & -3.2284 & -4.2108 & 0.0928 & -2.4 \\
\hline$<.08$ & 2.0 & 4.86 & 0.029 & 0.20 & $<.002$ & $<.008$ & 0.31 & $\mathrm{Ca}-\mathrm{Na}-\mathrm{HCO}_{3}-\mathrm{Cl}$ & -4.0529 & -4.4652 & -3.2022 & -6.9085 & -3.8186 & -4.0851 & -0.2784 & -16 \\
\hline$<.08$ & 1.7 & 4.42 & 0.031 & 0.12 & E.001 & $<.008$ & 0.24 & $\mathrm{Ca}-\mathrm{Na}-\mathrm{Cl}-\mathrm{HCO}_{3}-\mathrm{SO}_{4}$ & -4.0756 & -4.5221 & -3.7123 & -7.8749 & -3.8838 & -4.3282 & -0.4322 & 1.2 \\
\hline-- & -- & -- & -- & -- & -- & -- & -- & -- & -- & -- & -- & -- & -- & -- & -- & -- \\
\hline-- & -- & -- & -- & -- & -- & -- & -- & -- & -- & -- & -- & -- & -- & -- & -- & -- \\
\hline$<.08$ & 2.0 & 4.55 & $<.020$ & 0.16 & $<.002$ & $<.008$ & 0.20 & $\mathrm{Ca}-\mathrm{Na}-\mathrm{HCO}_{3}-\mathrm{Cl}$ & -4.0297 & -4.4461 & -2.5853 & -5.748 & -3.8142 & -3.9614 & -0.202 & -4.5 \\
\hline$<.08$ & 2.1 & 4.48 & $<.020$ & 0.18 & $<.002$ & $<.008$ & 0.25 & $\mathrm{Ca}-\mathrm{Na}-\mathrm{HCO}_{3}-\mathrm{Cl}-\mathrm{SO}_{4}$ & -4.098 & -4.5207 & -2.8753 & -6.3607 & -3.8822 & -4.0124 & -0.1634 & -8.0 \\
\hline$<.08$ & 3.0 & 11.1 & $<.020$ & 0.26 & $<.002$ & E.006 & 0.34 & $\mathrm{Ca}-\mathrm{HCO}_{3}$ & -3.3886 & -4.0324 & -0.9162 & -2.5553 & -2.8541 & -3.409 & -0.1131 & -3.1 \\
\hline E.05 & 7.8 & 44.0 & $<.020$ & 0.88 & 0.020 & E.005 & 0.94 & $\mathrm{Ca}-\mathrm{Mg}-\mathrm{HCO}_{3}$ & -2.9054 & -3.4089 & -0.1906 & -0.9673 & -1.8878 & -3.3838 & 0.3132 & -0.33 \\
\hline$<0.04$ & 2.7 & 9.2 & $<0.01$ & 0.24 & $<0.001$ & 0.0058 & -- & -- & -3.5851 & -4.2338 & -1.285 & -3.2977 & -3.1062 & -4.4468 & -0.152 & 0.69 \\
\hline 0.11 & 12 & 23 & 0.18 & $<0.04$ & $<.002$ & 0.048 & 0.20 & $\mathrm{Na}-\mathrm{Ca}-\mathrm{Cl}-\mathrm{HCO}_{3}$ & -3.0039 & -3.5328 & 0.1928 & -0.2079 & -2.2709 & -2.8165 & 0.4901 & -1.0 \\
\hline 0.1 & 11 & 25 & -- & -- & -- & -- & -- & $\mathrm{Ca}-\mathrm{HCO}_{3}-\mathrm{Cl}$ & -2.96 & -3.5268 & -55.03 & -1.7322 & -2.1732 & -2.6838 & 0.447 & -1.0 \\
\hline 0.1 & 11 & 26 & -- & -- & -- & -- & -- & $\mathrm{Ca}-\mathrm{HCO}_{3}$ & -2.96 & -3.5477 & -0.4101 & -1.3424 & -2.1662 & -2.9534 & 0.3182 & -0.87 \\
\hline 0.19 & 10 & 140 & 0.16 & $<0.04$ & $<.002$ & 0.013 & 0.18 & $\mathrm{Ca}-\mathrm{Mg}-\mathrm{Na}-\mathrm{SO}_{4}-\mathrm{HCO}_{3}$ & -3.1628 & -3.281 & -0.0319 & -0.2293 & -1.6361 & -2.5125 & 0.4056 & 1.2 \\
\hline 0.32 & 9.1 & 270 & 0.12 & $<0.04$ & $<.002$ & E.006 & 0.12 & $\mathrm{Ca}-\mathrm{Mg}-\mathrm{Na}-\mathrm{SO}_{4}$ & -3.0424 & -3.149 & -1.0502 & -2.2541 & -1.2671 & -1.967 & 0.345 & 5.2 \\
\hline 0.16 & 13 & 470 & 0.16 & $<0.04$ & $<.002$ & 0.009 & 0.14 & $\mathrm{Ca}-\mathrm{Mg}-\mathrm{SO}_{4}$ & -2.7527 & -3.1256 & 0.0235 & -0.3731 & -0.8111 & -2.1589 & 0.5135 & -1.5 \\
\hline 0.19 & 13 & 470 & 0.16 & E.03 & $<.002$ & 0.008 & 0.15 & $\mathrm{Ca}-\mathrm{Mg}-\mathrm{SO}_{4}$ & -- & -- & -- & -- & -- & -- & -- & -1.3 \\
\hline 0.16 & 13 & 430 & 0.15 & $<0.04$ & $<.002$ & E.006 & 0.15 & $\mathrm{Ca}-\mathrm{Mg}-\mathrm{SO}_{4}$ & -2.7913 & -3.1246 & 0.3555 & 0.3077 & -0.8747 & -2.3221 & 0.535 & -1.6 \\
\hline 0.38 & 9.9 & 330 & 0.58 & $<0.04$ & $<.002$ & 0.013 & 0.55 & $\mathrm{Na}-\mathrm{Ca}-\mathrm{Cl}-\mathrm{SO}_{4}$ & -2.8605 & -3.0973 & 0.2891 & 0.344 & -1.0832 & -1.7175 & 0.3346 & 2.9 \\
\hline 0.53 & 7.1 & 0.13 & 0.18 & $<0.02$ & $<0.001$ & 0.0079 & 0.21 & $\mathrm{Na}-\mathrm{Ca}-\mathrm{HCO}_{3}-\mathrm{Cl}$ & -3.7061 & -4.1093 & -1.5821 & -3.6268 & -5.1023 & -2.1041 & 0.2516 & 3.1 \\
\hline 0.31 & 6.7 & 0.31 & 0.4 & $<0.02$ & $<.001$ & 0.015 & 0.44 & $\mathrm{Na}-\mathrm{Ca}-\mathrm{HCO}_{3}$ & -3.5308 & -4.1321 & -0.0561 & -4.554 & -4.554 & -2.3871 & 0.2283 & 0.86 \\
\hline 0.09 & 12 & 49 & 0.1 & $<0.02$ & $<.001$ & 0.005 & 0.13 & $\mathrm{Ca}-\mathrm{Mg}-\mathrm{HCO}_{3}-\mathrm{SO}_{4}$ & -3.0497 & -3.405 & -0.3878 & -1.1118 & -1.9684 & -3.0443 & 0.4668 & 1.7 \\
\hline 0.34 & 9.4 & 26 & 0.32 & $<0.02$ & $<.001$ & 0.099 & 0.36 & $\mathrm{Na}-\mathrm{Ca}-\mathrm{Cl}-\mathrm{HCO}_{3}$ & -3.139 & -3.2759 & 0.0866 & 0.0144 & -2.3723 & -2.0249 & 0.3369 & 0.68 \\
\hline
\end{tabular}


Table 4. Concentrations of dissolved gases and age tracers, redox properties, and apparent age of surface-water and groundwater samples from a lake, New York, 2009-11.

[--, not measured; <, less than; E, estimated value below minimum reporting level; NP, age estimate not possible; $\mathrm{C}$, current age; apparent recharge years and ages for redox, oxidation-reduction; $\mathrm{O}_{2}$, oxygen reducing, $\mathrm{NO}_{3}{ }_{3}$, nitrate reducing; $\mathrm{Mn}$, manganese reducing; $\mathrm{Fe}$, iron reducing; $\mathrm{SO}_{4}^{2-}$, sulfate reducing; FeSO unless otherwise noted; mol $/ \mathrm{kg}$, moles per kilogram; pptv, parts per trillion by volume; pmol $/ \mathrm{kg}$, picomoles per kilogram; $\mathrm{cm}^{3} \mathrm{STP} / \mathrm{L}$, cubic centimeters at standard

\begin{tabular}{|c|c|c|c|c|c|c|c|c|c|c|c|c|c|c|c|}
\hline $\begin{array}{c}\text { Well } \\
\text { identifier }\end{array}$ & Date & $\begin{array}{c}\text { Sam- } \\
\text { ple } \\
\text { time }\end{array}$ & $\begin{array}{c}\text { Dis- } \\
\text { solved } \\
\text { oxygen } \\
\text { (D0) }\end{array}$ & $\begin{array}{l}\text { Sulfide } \\
\left(\mathrm{H}_{2} \mathrm{~S}\right)^{1}\end{array}$ & $\begin{array}{l}\text { Meth- } \\
\text { ane } \\
\left(\mathrm{CH}_{4}\right)^{1}\end{array}$ & $\begin{array}{l}\text { Nitro- } \\
\text { gen } \\
\left(\mathbf{N}_{2}\right)^{1}\end{array}$ & $\begin{array}{l}\text { Argon } \\
(\mathrm{Ar})^{1}\end{array}$ & $\begin{array}{c}\text { Carbon } \\
\text { diox- } \\
\text { ide } \\
\left(\mathrm{CO}_{2}\right)^{1}\end{array}$ & $\begin{array}{l}\text { Redox class } \\
\text { category }\end{array}$ & $\begin{array}{l}\text { Predominant } \\
\text { redox } \\
\text { process }\end{array}$ & $\begin{array}{c}\text { Re- } \\
\text { charge } \\
\text { temp } \\
\text { (degrees }^{\text {(degrius)' }}\end{array}$ & $\begin{array}{l}\text { Excess } \\
\text { air } \\
\left(\mathrm{cm}^{3}\right. \\
\text { STP/L) }\end{array}$ & $\begin{array}{l}\text { Tritium, } \\
\text { picocu- } \\
\text { ries } \\
\text { per } \\
\text { liter }^{2}\end{array}$ & $\begin{array}{c}\mathrm{SF}_{6} \text { in } \\
\text { water } \\
(\text { femto- } \\
\text { mol } / \mathrm{kg})^{3}\end{array}$ & $\begin{array}{c}\text { Calcu- } \\
\text { lated SF } \\
\text { partial } \\
\text { pressure } \\
\text { (pptv) }\end{array}$ \\
\hline U1626 & $12 / 15 / 2009$ & 1500 & 4.4 & 0.002 & $<0.001$ & 21 & 0.74 & 42 & $\begin{array}{l}\text { Mixed (oxic/ } \\
\text { sulfidic) }\end{array}$ & $\mathrm{O}_{2}-\mathrm{SO}_{4}^{2-}$ & 8.6 & 2.3 & 26.1 & 2.86 & 5.55 \\
\hline U1627 & $6 / 23 / 2009$ & 1200 & 5.6 & $<0.002$ & -- & -- & -- & -- & Oxic & $\mathrm{O}_{2}$ & -- & -- & -- & -- & -- \\
\hline U1627 & $4 / 1 / 2010$ & 0900 & 8.6 & $<0.002$ & $<0.001$ & 23 & 0.86 & 30 & Oxic & $\mathrm{O}_{2}$ & 6 & 3.9 & 27.5 & 3.59 & 5.65 \\
\hline U1637 & $8 / 31 / 2010$ & 1400 & 3 & -- & -- & -- & -- & -- & $\begin{array}{l}\text { Mixed (oxic- } \\
\text { methanogenic) }\end{array}$ & $\mathrm{O}_{2}-\mathrm{Fe}(\mathrm{III})$ & -- & -- & $<0.03$ & -- & -- \\
\hline U1641 & $4 / 20 / 2010$ & 1300 & 0.8 & 0.014 & 0.002 & 22 & 0.75 & 1.6 & $\begin{array}{l}\text { Mixed (oxic- } \\
\text { methanogenic) }\end{array}$ & $\mathrm{O}_{2}-\mathrm{CH}_{4}$ & 10.1 & 4.1 & 1.1 & 0.273 & 0.479 \\
\hline U1641 & $4 / 20 / 2010$ & 1301 & -- & -- & -- & -- & -- & -- & -- & -- & 10.1 & 4.1 & 1.1 & 0.279 & 0.489 \\
\hline U1663 & $8 / 31 / 2010$ & 1400 & 2.9 & -- & -- & -- & -- & -- & Oxic & $\mathrm{O}_{2}$ & -- & -- & 17.7 & -- & -- \\
\hline U1673 & $11 / 30 / 2011$ & 1200 & 0.5 & $<0.002$ & 0.0087 & 22.0 & 0.76 & 3.6 & $\begin{array}{l}\text { Mixed (oxic/ } \\
\text { methanogenic) }\end{array}$ & $\mathrm{O}_{2}-\mathrm{CH}_{4}$ & 7.8 & 3.8 & 0.20 & 1.03 & 1.77 \\
\hline U1670 & $11 / 30 / 2011$ & 1000 & 0.6 & $<0.002$ & 0.012 & 23.4 & 0.77 & 2.9 & $\begin{array}{l}\text { Mixed (oxic/ } \\
\text { methanogenic) }\end{array}$ & $\mathrm{O}_{2}-\mathrm{CH}_{4}$ & 9.6 & 6.0 & 0.30 & -- & -- \\
\hline U1632 & $9 / 14 / 2009$ & 1730 & 5.9 & -- & $<0.001$ & 20 & 0.72 & 30 & Oxic & $\mathrm{O}_{2}$ & 10.0 & 0.7 & 14.8 & 2.50 & 6.25 \\
\hline U1633 & $9 / 15 / 2009$ & 1200 & 8.5 & -- & -- & -- & -- & -- & Oxic & $\mathrm{O}_{2}$ & 8.7 & 1.5 & -- & -- & -- \\
\hline U1667 & 9/15/2009 & 1400 & 9.9 & -- & -- & -- & -- & -- & $\begin{array}{l}\text { Mixed (oxic/ } \\
\text { anoxic) }\end{array}$ & $\mathrm{O}_{2}-\mathrm{Mn}(\mathrm{IV})$ & -- & -- & -- & -- & -- \\
\hline U1668 & $7 / 1 / 2009$ & 1300 & 9.5 & -- & -- & -- & -- & -- & $\begin{array}{l}\text { Mixed (oxic/ } \\
\text { anoxic) }\end{array}$ & $\mathrm{O}_{2}-\mathrm{Mn}(\mathrm{IV})$ & -- & -- & -- & -- & -- \\
\hline U1666 & $6 / 23 / 2009$ & 1400 & 5.0 & -- & $<0.001$ & 17 & 0.64 & 74 & Oxic & $\mathrm{O}_{2}$ & 12.3 & 0 & 60 & 2.39 & 6.77 \\
\hline U1666 & $3 / 31 / 2010$ & 1600 & 7.7 & -- & $<0.001$ & 23 & 0.84 & 44 & Oxic & $\mathrm{O}_{2}$ & 6 & 2.0 & 26.9 & 3.42 & 5.75 \\
\hline U1665 & $3 / 31 / 2010$ & 1200 & 6.4 & E0.001 & $<0.001$ & 24 & 0.88 & 28 & Oxic & $\mathrm{O}_{2}$ & 1.2 & 2.2 & 24.8 & 3.72 & 5.55 \\
\hline $\begin{array}{l}\text { Lippman Lake } \\
\text { effluent }\end{array}$ & $6 / 24 / 2009$ & 1330 & -- & -- & -- & -- & -- & -- & $\mathrm{O}_{2} \geq 0.5 \mathrm{mg} / \mathrm{L}$ & -- & -- & -- & -- & -- & -- \\
\hline $\begin{array}{l}\text { Lippman Lake } \\
\text { effluent }\end{array}$ & 7/2/2009 & 1300 & 8.9 & -- & -- & -- & -- & -- & $\mathrm{O}_{2} \geq 0.5 \mathrm{mg} / \mathrm{L}$ & $\mathrm{O}_{2}-\mathrm{Mn}(\mathrm{IV})$ & $10^{*}$ & 0 & -- & -- & -- \\
\hline $\begin{array}{l}\text { Lippman Lake } \\
\text { effluent }\end{array}$ & $9 / 1 / 2009$ & 1230 & -- & -- & -- & -- & -- & -- & $\mathrm{O}_{2} \geq 0.5 \mathrm{mg} / \mathrm{L}$ & -- & -- & -- & -- & -- & -- \\
\hline $\begin{array}{l}\text { Lippman Lake } \\
\text { effluent }\end{array}$ & $9 / 16 / 2009$ & 1300 & 11 & -- & -- & -- & -- & -- & Oxic & $\mathrm{O}_{2}$ & -- & -- & -- & -- & -- \\
\hline $\begin{array}{l}\text { Lippman Lake } \\
\text { effluent }\end{array}$ & 10/13/2009 & 1515 & -- & -- & -- & -- & -- & -- & $\mathrm{O}_{2} \geq 0.5 \mathrm{mg} / \mathrm{L}$ & -- & -- & -- & -- & -- & -- \\
\hline $\begin{array}{l}\text { Lippman Lake } \\
\text { effluent }\end{array}$ & $12 / 15 / 2009$ & 1000 & 7.3 & -- & -- & -- & -- & -- & $\begin{array}{l}\text { Mixed (oxic/ } \\
\text { anoxic) }\end{array}$ & $\mathrm{O}_{2}-\mathrm{Mn}(\mathrm{IV})$ & $7 \#$ & 0 & -- & -- & -- \\
\hline $\begin{array}{l}\text { Lippman Lake } \\
\text { effluent }\end{array}$ & $4 / 1 / 2010$ & 1200 & 9.9 & -- & -- & -- & -- & -- & $\begin{array}{l}\text { Mixed (oxic/ } \\
\text { anoxic) }\end{array}$ & $\mathrm{O}_{2}-\mathrm{Mn}(\mathrm{IV})$ & -- & -- & -- & -- & -- \\
\hline 01366400 & $6 / 23 / 2009$ & 0930 & 9.6 & -- & -- & -- & -- & -- & Oxic & $\mathrm{O}_{2}$ & $10^{\&}$ & 0 & -- & -- & -- \\
\hline 01366400 & $9 / 1 / 2009$ & 1030 & -- & -- & -- & -- & -- & -- & Oxic & $\mathrm{O}_{2}$ & -- & -- & -- & -- & -- \\
\hline 01366400 & $10 / 13 / 2009$ & 1420 & -- & -- & -- & -- & -- & -- & $\mathrm{O}_{2} \geq 0.5 \mathrm{mg} / \mathrm{L}$ & -- & -- & -- & -- & -- & -- \\
\hline 01366400 & $10 / 13 / 2009$ & 1425 & -- & -- & -- & -- & -- & -- & $\mathrm{O}_{2} \geq 0.5 \mathrm{mg} / \mathrm{L}$ & -- & -- & -- & -- & -- & -- \\
\hline 01366400 & $12 / 22 / 2009$ & 1110 & -- & -- & -- & -- & -- & -- & Oxic & $\mathrm{O}_{2}$ & $7^{\&}$ & 0 & -- & -- & -- \\
\hline
\end{tabular}


springs, and wells in the Wawarsing study area, and for the Rondout Reservoir at the influent to the Rondout-West Branch Tunnel in Lackawack, Ulster County,

$\mathrm{SF}_{6}$ and $\mathrm{CFCs}$ have been corrected for excess air; $\mathrm{SF}_{6}$, Sulfur hexafluoride; $\mathrm{CFC}$, chlorofluorocarbon; bold text indicates most reasonable apparent age or recharge year; reducing; $\mathrm{CH}_{4}$, methanogenic; mixed (Y/Z) indicates waters with different redox ranging from most oxidized (Y) to most reduced (Z); concentrations in milligrams per liter, temperature and pressure per liter; $\mathrm{pCi}$, picocuries per liter]

\begin{tabular}{|c|c|c|c|c|c|c|c|c|c|c|c|}
\hline $\begin{array}{l}\mathrm{SF}_{6} \mathrm{Ap}- \\
\text { parent } \\
\text { recharge } \\
\text { year, pis- } \\
\text { ton flow }\end{array}$ & $\begin{array}{c}\mathrm{SF}_{6} \\
\text { Appar- } \\
\text { ent age, } \\
\text { piston } \\
\text { flow }^{3}\end{array}$ & $\begin{array}{c}\text { CFC-11 } \\
\text { corrected } \\
\text { concen- } \\
\text { tration } \\
(\mathrm{pmol} / \mathrm{kg})^{3}\end{array}$ & $\begin{array}{c}\text { CFC-12 } \\
\text { corrected } \\
\text { concentra- } \\
\text { tion } \\
(\mathrm{pmol} / \mathrm{kg})^{3}\end{array}$ & $\begin{array}{c}\text { CFC-113 } \\
\text { corrected } \\
\text { concentra- } \\
\text { tion } \\
(\mathrm{pmol} / \mathrm{kg})^{3}\end{array}$ & $\begin{array}{l}\text { CFC-11 } \\
\text { Apparent } \\
\text { age piston } \\
\text { flow } \\
\text { (years) }\end{array}$ & $\begin{array}{l}\text { CFC-12 } \\
\text { Apparent } \\
\text { age } \\
\text { piston } \\
\text { flow } \\
\text { (years) }^{3}\end{array}$ & $\begin{array}{c}\text { CFC-113 } \\
\text { Apparent } \\
\text { age } \\
\text { piston } \\
\text { flow } \\
\text { (years) }^{3}\end{array}$ & $\begin{array}{c}\text { CFC-11 } \\
\text { Apparent } \\
\text { recharge } \\
\text { year, } \\
\text { piston } \\
\text { flow }^{3}\end{array}$ & $\begin{array}{c}\text { CFC-12 } \\
\text { Apparent } \\
\text { recharge } \\
\text { year, } \\
\text { piston } \\
\text { flow }^{3}\end{array}$ & $\begin{array}{c}\text { CFC-113 } \\
\text { Apparent } \\
\text { recharge } \\
\text { year, } \\
\text { piston } \\
\text { flow }^{3}\end{array}$ & Dissolved gas notes \\
\hline 2004.0 & 6.0 & 0.742 & 1.46 & 0.141 & 44.0 & 34.0 & 31.2 & 1966 & 1976 & 1978.8 & \\
\hline-- & -- & -- & -- & -- & -- & -- & -- & -- & -- & -- & Jet pump, not sampled \\
\hline 2004.5 & 5.8 & 4.08 & 3.63 & 0.591 & 32.0 & 14.0 & 21.3 & 1978.3 & 1996.3 & 1989.0 & \\
\hline-- & -- & -- & -- & -- & -- & -- & -- & -- & -- & -- & $\begin{array}{l}\text { Poor yield, gas sample not } \\
\text { possible }\end{array}$ \\
\hline 1975.5 & 34.8 & 0.371 & 0.992 & 0.058 & 47.3 & 37.8 & 37.3 & 1963 & 1972.5 & 1973 & \\
\hline 1976.0 & 34.3 & 0.373 & 0.955 & 0.058 & 47.3 & 37.8 & 37.3 & 1963 & 1972.5 & 1973 & \\
\hline -- & -- & -- & -- & -- & -- & -- & -- & -- & -- & -- & $\begin{array}{l}\text { Poor yield, gas sample not } \\
\text { possible }\end{array}$ \\
\hline 1986.8 & 25.2 & 44.8 & 4,459 & 0.0298 & NP & NP & 44.6 & NP & NP & 1967.3 & Trace $\mathrm{CH}_{4}$ \\
\hline
\end{tabular}

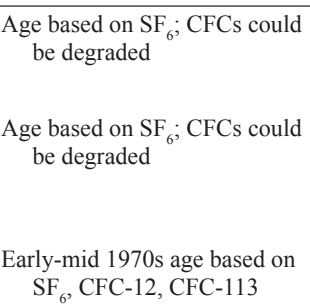

Age based on $\mathrm{SF}_{6}$; $\mathrm{CFCs}$ could be degraded

Early-mid 1970s age based on $\mathrm{SF}_{6}, \mathrm{CFC}-12$, CFC-113

Early-mid 1970s age based on $\mathrm{SF}_{6}, \mathrm{CFC} 12, \mathrm{CFC}-113$

Age estimated using CFC-113; CFC-12 and -11 were contaminated

Late 2000s age based on $\mathrm{SF}_{6}$, CFC-11, -12

-- $\quad$ Poor yield, gas sample not possible

-- Poor yield, gas sample not possible

$\begin{array}{llllllllllll}\mathbf{2 0 0 9 . 5} & \mathbf{0} & 5.59 & 2.60 & 0.485 & \mathrm{C} & \mathbf{3 . 5} & 14.0 & \text { C } & \mathbf{2 0 0 6} & 1995.5 & \text { Slight degassing } \\ \mathbf{2 0 0 5 . 0} & \mathbf{5 . 2} & 5.96 & 3.55 & 0.663 & 24.0 & \mathbf{0 . 2} & \mathbf{5 . 2} & 1986 & \mathbf{2 0 1 0 . 1} & \mathbf{2 0 0 5 . 0} & \\ \mathbf{2 0 0 4 . 3} & \mathbf{6 . 0} & 4.41 & 3.79 & 0.619 & 35 & \text { NP } & 23 & 1975.5 & \text { NP } & 1986.8 & \end{array}$

\subsection{6}

\section{$1.97 \quad 0.231$}

34.

\section{5}

$$
-
$$$$
--
$$$$
5.07
$$$$
4.5
$$$$
0.651
$$$$
25.5
$$$$
\text { C }
$$$$
11
$$$$
26.0
$$$$
1975.0
$$$$
975.0
$$$$
1983.0
$$

1983.5

1984.5$$
\text { C }
$$$$
6.07
$$

$$
3.20 \quad 0.532
$$$$
\text { C }
$$$$
\text { C }
$$

C

1994.8

$\begin{array}{lll}1977.5 & 1991.5 \quad 1988.5\end{array}$
Late 2000s; CFCs could be degraded

Mid-late 2000s age based on $\mathrm{SF}_{6}$, and CFC-12, -113

Age based on $\mathrm{SF}_{6}$; $\mathrm{CFC}-12$ age not possible

Modern; degradation of CFCs in surface water

Modern; surface water CFC$11,-12$, and -113 degraded

\footnotetext{
CFCs slightly higher than modern water; CFC-12, -113 contaminated
} 
Table 4. Concentrations of dissolved gases and age tracers, redox properties, and apparent age of surface-water and groundwater samples from a lake, New York, 2009-11.-Continued

[--, not measured; <, less than; E, estimated value below minimum reporting level; NP, age estimate not possible; $\mathrm{C}$, current age; apparent recharge years and ages for redox, oxidation-reduction; $\mathrm{O}_{2}$, oxygen reducing, $\mathrm{NO}_{3}$, nitrate reducing; $\mathrm{Mn}$, manganese reducing; $\mathrm{Fe}$, iron reducing; $\mathrm{SO}_{4}{ }^{2-}$, sulfate reducing; FeSO${ }_{4}$, iron- to sulfateunless otherwise noted; mol $/ \mathrm{kg}$, moles per kilogram; pptv, parts per trillion by volume; pmol $/ \mathrm{kg}$, picomoles per kilogram; $\mathrm{cm}^{3} \mathrm{STP} / \mathrm{L}$, cubic centimeters at standard

\begin{tabular}{|c|c|c|c|c|c|c|c|c|c|c|c|c|c|c|c|}
\hline $\begin{array}{c}\text { Well } \\
\text { identifier }\end{array}$ & Date & $\begin{array}{c}\text { Sam- } \\
\text { ple } \\
\text { time }\end{array}$ & $\begin{array}{c}\text { Dis- } \\
\text { solved } \\
\text { oxygen } \\
\text { (D0) }\end{array}$ & $\begin{array}{l}\text { Sulfide } \\
\left(\mathrm{H}_{2} \mathrm{~S}\right)^{1}\end{array}$ & $\begin{array}{c}\text { Meth- } \\
\text { ane } \\
\left(\mathrm{CH}_{4}\right)^{1}\end{array}$ & $\begin{array}{l}\text { Nitro- } \\
\text { gen } \\
\left(\mathrm{N}_{2}\right)^{1}\end{array}$ & $\begin{array}{c}\text { Argon } \\
(\mathrm{Ar})^{1}\end{array}$ & $\begin{array}{c}\text { Carbon } \\
\text { diox- } \\
\text { ide } \\
\left(\mathrm{CO}_{2}\right)^{1}\end{array}$ & $\begin{array}{l}\text { Redox class } \\
\text { category }\end{array}$ & $\begin{array}{l}\text { Predominant } \\
\text { redox } \\
\text { process }\end{array}$ & $\begin{array}{c}\text { Re- } \\
\text { charge } \\
\text { temp } \\
\text { (degrees } \\
\text { Celsius) }\end{array}$ & $\begin{array}{c}\text { Excess } \\
\text { air } \\
\left(\mathrm{cm}^{3}\right. \\
\text { STP/L) })^{1}\end{array}$ & $\begin{array}{c}\text { Tritium, } \\
\text { picocu- } \\
\text { ries } \\
\text { per } \\
\text { liter }^{2}\end{array}$ & $\begin{array}{c}\mathrm{SF}_{6} \text { in } \\
\text { water } \\
\text { (femto- } \\
\mathrm{mol} / \mathrm{kg})^{3}\end{array}$ & $\begin{array}{c}\text { Calcu- } \\
\text { lated SF }_{6} \\
\text { partial }^{2} \\
\text { pressure } \\
(\mathrm{pptv})^{3}\end{array}$ \\
\hline 01366400 & $4 / 1 / 2010$ & 1000 & 9.9 & -- & -- & -- & -- & -- & Oxic & $\mathrm{O}_{2}$ & $5.4^{\&}$ & 0 & -- & -- & -- \\
\hline U1625 & $6 / 24 / 2009$ & 1100 & 3.2 & $<0.002$ & $<0.001$ & 19.0 & 0.72 & 4.5 & Oxic & $\mathrm{O}_{2}$ & 8 & 0.65 & 27.2 & 2.4 & 5.32 \\
\hline U1625 & $12 / 14 / 2009$ & 1000 & 2.1 & 0.093 & 0.022 & 22.5 & 0.8 & 23.1 & $\begin{array}{l}\text { Mixed (oxic/ } \\
\text { methanogenic) }\end{array}$ & $\mathrm{O}_{2}-\mathrm{CH}_{4}$ & 9.4 & 4.5 & 25.3 & 2.85 & 4.75 \\
\hline U1629 & $6 / 24 / 2009$ & 0800 & $<0.2$ & 0.56 & 15 & 22.0 & 0.78 & 5.5 & Anoxic & $\mathrm{Fe}(\mathrm{III})-\mathrm{SO}_{4}{ }^{2-}-\mathrm{CH}_{4}$ & 7.3 & 3.2 & 19.5 & 0.0282 & 0.05 \\
\hline U1628 & $7 / 2 / 2009$ & 1000 & 0.6 & 1.2 & 0.16 & 31.0 & 0.98 & 1.2 & $\begin{array}{l}\text { Mixed (oxic/ } \\
\text { methanogenic) }\end{array}$ & $\mathrm{O}_{2}-\mathrm{CH}_{4}$ & NP & NP & 8.3 & 0.13 & 0.13 \\
\hline U1630 & $9 / 15 / 2009$ & 1700 & 1.5 & 0.012 & $<0.001$ & 48.0 & 1.4 & 2.2 & $\begin{array}{l}\text { Mixed (oxic/ } \\
\text { sulfidic) }\end{array}$ & $\mathrm{O}_{2}-\mathrm{Mn}(\mathrm{IV})-\mathrm{SO}_{4}{ }^{2-}$ & NP & NP & 3.7 & 1.17 & 1.37 \\
\hline U1631 & $9 / 16 / 2009$ & 1000 & 1.4 & 0.65 & 0.51 & 34.0 & 1.07 & 3.8 & $\begin{array}{l}\text { Mixed (oxic/ } \\
\text { methanogenic) }\end{array}$ & $\mathrm{O}_{2}-\mathrm{Fe}(\mathrm{III})-\mathrm{CH}_{4}$ & NP & NP & 2.9 & 0.86 & 1.37 \\
\hline U1631 & $9 / 16 / 2009$ & 1001 & 1.4 & 0.65 & 0.5 & 33.0 & 1.05 & 3.8 & $\begin{array}{l}\text { Mixed (oxic/ } \\
\text { methanogenic) }\end{array}$ & $\mathrm{O}_{2}-\mathrm{Fe}(\mathrm{III})-\mathrm{CH}_{4}$ & NP & NP & 2.6 & 0.50 & 1.30 \\
\hline U1631 & $12 / 14 / 2009$ & 1630 & 1.8 & 2.3 & 0.34 & 33.0 & 1.05 & 2.2 & $\begin{array}{l}\text { Mixed (oxic/ } \\
\text { methanogenic) }\end{array}$ & $\mathrm{O}_{2}-\mathrm{SO}_{4}{ }^{2-}-\mathrm{CH}_{4}$ & NP & NP & 2.8 & 0.50 & 0.47 \\
\hline U1647 & $4 / 21 / 2010$ & 1300 & $<0.2$ & 2.0 & 18 & 36.0 & 1.10 & 3.4 & Anoxic & $\mathrm{Mn}(\mathrm{IV})-\mathrm{CH}_{4}$ & NP & NP & $<0.3$ & 0.32 & 0.26 \\
\hline U7017 & 9/20/2011 & 1200 & $<0.2$ & 0.039 & 13 & 25.8 & 0.88 & 13.4 & Anoxic & $\mathrm{Mn}(\mathrm{IV})-\mathrm{CH}_{4}$ & 3.0 & 5.4 & 4.1 & 0.0888 & 0.12 \\
\hline U3772 & 9/20/2011 & 1200 & $<0.2$ & 0.006 & 6.2 & 24.0 & 0.83 & 1.3 & Anoxic & $\mathrm{Fe}(\mathrm{III})-\mathrm{CH}_{4}$ & 4.5 & 4.3 & 0.70 & 0.446 & 0.66 \\
\hline U1645 & 9/21/2011 & 1200 & 0.4 & 0.023 & 0.054 & 22.1 & 0.77 & 6.1 & Anoxic & $\mathrm{Mn}(\mathrm{IV})-\mathrm{CH}_{4}$ & 7.6 & 3.6 & 15 & 0.141 & 0.24 \\
\hline U1644 & $9 / 21 / 2011$ & 1200 & $<0.2$ & 0.80 & 16 & 23.4 & 0.84 & 2.5 & Anoxic & $\mathrm{Mn}(\mathrm{IV})-\mathrm{CH}_{4}$ & 3.3 & 2.9 & 8.1 & 0.17 & 0.26 \\
\hline
\end{tabular}

'Analyzed or estimated at the U.S. Geological Survey (USGS) Dissolved Gas Laboratory, Reston, Va.

${ }^{2}$ Analyzed at a USGS contract laboratory.

${ }^{3}$ Analyzed or estimated at the USGS CFC Laboratory, Reston, Va.

"Estimated based on mean annual temperature.

\&Estimated based on sample temperature.

"Estimated based on average air temperature for November and December at Wawarsing, N.Y. 
springs, and wells in the Wawarsing study area, and for the Rondout Reservoir at the influent to the Rondout-West Branch Tunnel in Lackawack, Ulster County,

$\mathrm{SF}_{6}$ and $\mathrm{CFCs}$ have been corrected for excess air; $\mathrm{SF}_{6}$, Sulfur hexafluoride; $\mathrm{CFC}$, chlorofluorocarbon; bold text indicates most reasonable apparent age or recharge year; reducing; $\mathrm{CH}_{4}$, methanogenic; mixed $(\mathrm{Y} / \mathrm{Z})$ indicates waters with different redox ranging from most oxidized $(\mathrm{Y})$ to most reduced $(\mathrm{Z})$; concentrations in milligrams per liter, temperature and pressure per liter; $\mathrm{pCi}$, picocuries per liter]

\begin{tabular}{|c|c|c|c|c|c|c|c|c|c|c|c|c|}
\hline $\begin{array}{l}\mathrm{SF}_{6} \mathrm{Ap}- \\
\text { parent } \\
\text { recharge } \\
\text { year, pis- } \\
\text { ton flow }\end{array}$ & $\begin{array}{c}\mathrm{SF}_{6} \\
\text { Appar- } \\
\text { ent age, } \\
\text { piston } \\
\text { flow }^{3}\end{array}$ & $\begin{array}{c}\text { CFC-11 } \\
\text { corrected } \\
\text { concen- } \\
\text { tration } \\
(\mathrm{pmol} / \mathrm{kg})^{3}\end{array}$ & $\begin{array}{c}\text { CFC-12 } \\
\text { corrected } \\
\text { concentra- } \\
\text { tion } \\
(\mathrm{pmol} / \mathrm{kg})^{3}\end{array}$ & $\begin{array}{c}\text { CFC-113 } \\
\text { corrected } \\
\text { concentra- } \\
\text { tion } \\
(\mathrm{pmol} / \mathrm{kg})^{3}\end{array}$ & $\begin{array}{l}\text { CFC-11 } \\
\text { Apparent } \\
\text { age piston } \\
\text { flow } \\
\text { (years) }^{3}\end{array}$ & $\begin{array}{l}\text { CFC-12 } \\
\text { Apparent } \\
\text { age } \\
\text { piston } \\
\text { flow } \\
\text { (years) }^{3}\end{array}$ & $\begin{array}{l}\text { CFC-113 } \\
\text { Apparent } \\
\text { age } \\
\text { piston } \\
\text { flow } \\
\text { (years) }^{3}\end{array}$ & $\begin{array}{c}\text { CFC-11 } \\
\text { Apparent } \\
\text { recharge } \\
\text { year, } \\
\text { piston } \\
\text { flow }^{3}\end{array}$ & $\begin{array}{c}\text { CFC-12 } \\
\text { Apparent } \\
\text { recharge } \\
\text { year, } \\
\text { piston } \\
\text { flow }^{3}\end{array}$ & $\begin{array}{c}\text { CFC-113 } \\
\text { Apparent } \\
\text { recharge } \\
\text { year, } \\
\text { piston } \\
\text { flow }^{3}\end{array}$ & Dissolved gas notes & Age tracer notes \\
\hline-- & -- & 5.05 & 3.87 & 0.645 & 27.0 & $\mathrm{C}$ & 5.6 & 1982.8 & $\mathrm{C}$ & 2008.2 & & $\begin{array}{l}\text { CFC-12 contaminated; CFC-11 } \\
\text { and }-113 \text { degraded }\end{array}$ \\
\hline 2003.0 & 6.5 & 5.25 & 3.28 & 0.464 & 23.15 & 6.65 & 21.25 & 1986.3 & 20028 & 1988 & & Early 2000 s age \\
\hline 2000.5 & 9.5 & 1.08 & 1.75 & 0.154 & 41.12 & 30.45 & 30.29 & 1968.8 & 1979.5 & 1979.7 & Presence of $\mathrm{CH}_{4}$ & $\begin{array}{l}\text { Conflicting ages, CFCs could } \\
\text { be degraded }\end{array}$ \\
\hline 19520 & 57.5 & 0.0857 & 0.0197 & 0 & 55.0 & $\mathbf{2 . 7}$ & 56.5 & 1954.5 & 1946.8 & 1953 & High $\mathrm{CH}_{4}$ & $\begin{array}{l}\text { Late } 1940 \text { s }-1950 \text { s age; tracers } \\
\text { could be degraded }\end{array}$ \\
\hline NP & NP & 0.0905 & 0.0425 & 0 & NP & NP & NP & NP & NP & NP & Excess air; presence of $\mathrm{CH}_{4}$ & Age uncertain \\
\hline NP & NP & 0.284 & 0.584 & 0.0533 & NP & NP & NP & NP & NP & NP & Excess air & $\begin{array}{l}\text { Age uncertain. Probably a } \\
\text { mixture of water ages }\end{array}$ \\
\hline NP & NP & 0.0875 & 0.0212 & 0.00583 & NP & NP & NP & NP & NP & NP & Excess air; presence of $\mathrm{CH}_{4}$ & $\begin{array}{l}\text { Age uncertain. CFCs chro- } \\
\text { matograms appear degraded }\end{array}$ \\
\hline NP & NP & 0.0803 & 0.0167 & 0.0063 & NP & NP & NP & NP & NP & NP & Excess air; presence of $\mathrm{CH}_{4}$ & $\begin{array}{l}\text { Age uncertain. CFCs could be } \\
\text { slightly degraded }\end{array}$ \\
\hline NP & NP & 0.0925 & 0.0065 & 0.030 & NP & NP & NP & $\mathrm{NP}$ & NP & NP & Excess air & $\begin{array}{l}\text { Age uncertain. CFCs are } \\
\text { degraded }\end{array}$ \\
\hline NP & NP & 0 & 0.429 & 0.075 & NP & NP & NP & NP & NP & NP & Excess air & $\begin{array}{l}\text { Age uncertain. CFC-11 } \\
\text { degraded }\end{array}$ \\
\hline 1964.5 & 47.2 & 0.157 & 0.0501 & 0.0235 & NP & NP & NP & $\mathrm{NP}$ & NP & NP & Excess air; presence of $\mathrm{CH}_{4}$ & $\begin{array}{l}\text { Age uncertain. CFCs are } \\
\text { degraded }\end{array}$ \\
\hline 1978.3 & 33.5 & 0.311 & 0.243 & 0.0761 & NP & NP & NP & NP & NP & NP & Excess air; presence of $\mathrm{CH}_{4}$ & $\begin{array}{l}\text { Age uncertain. CFCs are } \\
\text { degraded }\end{array}$ \\
\hline 1970.3 & 41.5 & 0.286 & 0.15 & 0.0665 & 51.2 & 54.5 & NP & 1960.5 & 1957.2 & NP & Trace $\mathrm{CH}_{4}$ & $\begin{array}{l}1970 \text { age based on } \mathrm{SF}_{6} ; \mathrm{CFC}- \\
113 \text { and possibly } \mathrm{CFC}-11 \\
-12 \text { degraded }\end{array}$ \\
\hline 1970.8 & 41.0 & 0.131 & 0.0716 & 0.074 & NP & NP & NP & NP & NP & NP & Excess air; presence of $\mathrm{CH}_{4}$ & $\begin{array}{l}\text { Age uncertain. CFCs are } \\
\text { degraded }\end{array}$ \\
\hline
\end{tabular}


Table 5. Dissolved concentrations of trace elements and stable-isotope ratios in surface-water and groundwater samples from a lake, springs, County, New York, 2009-11.

[Analytes measured by the U.S. Geological Survey National Water Quality Laboratory unless otherwise noted; concentrations in micrograms per liter, $(\mu \mathrm{g} / \mathrm{L})$ unless $\mathrm{Be}$, beryllium; B, boron; $\mathrm{Cd}$, cadmium; Cr, chromium; Co, cobalt; $\mathrm{Cu}$, copper; Fe, iron; Pb, lead; Li, lithium; Mn, manganese; Mo, molybdenum; Ni, nickel; N, nitrogen; isotope ratio of hydrogen-2 to hydrogen- $1 ; \delta^{18} \mathrm{O}$, stable isotope ratio of oxygen-18 to oxygen-16, relative to Vienna Standard Mean Ocean Water standard; $\delta^{34} \mathrm{~S}$, stable ganic carbon relative to the Vienna Pee Dee Belemnite standard; SI, saturation index]

\begin{tabular}{|c|c|c|c|c|c|c|c|c|c|c|c|c|c|}
\hline Well identifier & Date & $\begin{array}{c}\text { Sample } \\
\text { time }\end{array}$ & Al & $\mathrm{Ba}$ & $\mathrm{Be}$ & Cd & $\mathrm{Cr}$ & Co & Cu & $\mathrm{Fe}$ & $\mathbf{P b}$ & Li & Mn \\
\hline U1626 & $12 / 15 / 2009$ & 1500 & E2.9 & 26 & $<0.01$ & E0.01 & 0.24 & 0.23 & E0.96 & 290 & $<0.03$ & 0.8 & 79 \\
\hline U1627 & $6 / 23 / 2009$ & 1200 & $<4.0$ & 29 & $<0.02$ & $<0.02$ & E0.07 & 0.07 & 35.1 & 4 & 0.81 & 1.6 & 0.2 \\
\hline U1627 & $4 / 1 / 2010$ & 0900 & 11.8 & 24 & $<0.01$ & $<0.02$ & E0.11 & 0.05 & E0.78 & $<6$ & $<0.03$ & 1.2 & $<0.3$ \\
\hline U1637 & $8 / 31 / 2010$ & 1400 & 190 & 140 & 0.014 & 0.029 & 0.34 & 0.3 & $<1.0$ & 420 & 0.26 & 2.9 & 630 \\
\hline U1641 & $4 / 20 / 2010$ & 1300 & $<17.0$ & 83 & $<0.06$ & $<0.10$ & $<0.60$ & 2.2 & $<5.0$ & 92 & $<0.15$ & 4.3 & 130 \\
\hline U1641 & $4 / 20 / 2010$ & 1301 & $<17.0$ & 84 & $<0.06$ & $<0.10$ & $<0.60$ & 2.0 & $<5.0$ & 91 & $<0.15$ & 4.2 & 130 \\
\hline U1663 & $8 / 31 / 2010$ & 1400 & 7.8 & 54 & E0.01 & 0.04 & $<0.120$ & 0.068 & E0.92 & 2.3 & $<0.03$ & 90 & 41 \\
\hline U1673 & $11 / 30 / 2011$ & 1200 & $<2.2$ & 240 & $<0.006$ & $<0.02$ & $<0.07$ & 0.08 & 2.8 & 24 & 0.15 & 2.9 & 260 \\
\hline U1670 & $11 / 30 / 2011$ & 1000 & $<2.2$ & 180 & $<0.006$ & $<0.02$ & $<0.07$ & 0.03 & 0.95 & 34 & 0.08 & 3 & 190 \\
\hline U1632 & $9 / 14 / 2009$ & 1730 & E3.6 & 13 & $<0.02$ & E0.01 & 0.19 & 0.08 & $<1.0$ & $<4$ & $<0.06$ & $<1.0$ & 16 \\
\hline U1633 & $9 / 15 / 2009$ & 1200 & $<4.0$ & 15 & $<0.02$ & 0.03 & 0.33 & 0.04 & $<1.0$ & E2 & $<0.06$ & E0.7 & 18 \\
\hline U1667 & $9 / 15 / 2009$ & 1400 & 20 & 14 & E0.02 & E0.02 & 0.21 & 0.07 & $<1.0$ & 53 & 0.11 & E0.7 & 19 \\
\hline U1668 & 7/1/2009 & 1300 & 15.9 & 14 & $<0.02$ & $<0.02$ & $<0.12$ & 0.1 & 2.5 & 248 & $<0.06$ & E0.7 & 21 \\
\hline U1666 & $6 / 23 / 2009$ & 1400 & $<4.0$ & 25 & $<0.02$ & $<0.02$ & $<0.12$ & 0.08 & E0.77 & $<4$ & $<0.06$ & 1.8 & $<0.2$ \\
\hline U1666 & $3 / 31 / 2010$ & 1600 & E1.9 & 23 & $<0.01$ & $<0.02$ & E0.08 & 0.06 & $<1.0$ & $<6$ & $<0.03$ & 2.3 & $<0.3$ \\
\hline U1665 & $3 / 31 / 2010$ & 1200 & 7.9 & 14 & $<0.01$ & E0.01 & E0.10 & 0.03 & $<1.0$ & 6 & E0.02 & $<0.4$ & 9.8 \\
\hline Lippman Lake effluent & $6 / 24 / 2009$ & 1330 & -- & -- & -- & -- & -- & -- & -- & -- & -- & -- & -- \\
\hline Lippman Lake effluent & 7/2/2009 & 1300 & 28 & 10 & $<0.02$ & E0.01 & 0.14 & 0.10 & $<1.0$ & 317 & 0.16 & E0.7 & 51 \\
\hline Lippman Lake effluent & $9 / 1 / 2009$ & 1230 & -- & -- & -- & -- & -- & -- & -- & -- & -- & -- & -- \\
\hline Lippman Lake effluent & $9 / 16 / 2009$ & 1300 & 34 & 19 & $<0.02$ & $<0.02$ & E0.10 & 0.08 & $<1.0$ & 34 & $<0.06$ & 3.7 & 2.1 \\
\hline Lippman Lake effluent & $10 / 13 / 2009$ & 1515 & -- & -- & -- & -- & -- & -- & -- & -- & -- & -- & -- \\
\hline Lippman Lake effluent & $12 / 15 / 2009$ & 1000 & 140 & 6 & $<0.01$ & $<0.02$ & $<0.12$ & 0.12 & $<1.0$ & 142 & 0.05 & 1.2 & 86 \\
\hline Lippman Lake effluent & $4 / 1 / 2010$ & 1200 & 58 & 7 & $<0.01$ & $<0.02$ & E0.06 & 0.49 & $<1.0$ & 58 & E0.03 & 1.6 & 48 \\
\hline 01366400 & 6/23/2009 & 0930 & 6.1 & 26 & $<0.02$ & $<0.02$ & $<0.12$ & E0.01 & 1.3 & E4 & $<0.06$ & $<1.0$ & 1.7 \\
\hline 01366400 & $9 / 1 / 2009$ & 1030 & 26 & 29 & 0.02 & E0.02 & E0.08 & 0.02 & 18.1 & 6 & 0.34 & E0.6 & 3.2 \\
\hline 01366400 & $10 / 13 / 2009$ & 1420 & -- & -- & -- & -- & -- & -- & -- & -- & -- & -- & -- \\
\hline 01366400 & $10 / 13 / 2009$ & 1425 & -- & -- & -- & -- & -- & -- & -- & -- & -- & -- & -- \\
\hline 01366400 & $12 / 22 / 2009$ & 1110 & 4.8 & 26 & E0.01 & $<0.02$ & 0.18 & 0.03 & E0.94 & E5 & E0.02 & 0.4 & 1.5 \\
\hline 01366400 & $4 / 1 / 2010$ & 1000 & 17 & 30 & E0.01 & 0.02 & $<0.12$ & 0.02 & E0.86 & 8 & E0.02 & 0.5 & 5.2 \\
\hline U1625 & $6 / 24 / 2009$ & 1100 & $<4.0$ & 42 & $<0.02$ & $<0.02$ & $<0.12$ & 0.02 & 10.7 & $<4$ & 0.23 & 7.2 & 0.2 \\
\hline U1625 & $12 / 14 / 2009$ & 1000 & $<3.4$ & 130 & $<0.01$ & E0.01 & $<0.12$ & 0.37 & 1.1 & E5 & 0.44 & 20 & 13 \\
\hline U1625 & 4/7/2011 & 1900 & 11.2 & 24 & $<0.006$ & $<0.016$ & 0.11 & 0.068 & 1.1 & 54 & 0.028 & 4.4 & 7.6 \\
\hline U1629 & $6 / 24 / 2009$ & 0800 & $<20.0$ & 230 & $<0.10$ & $<0.10$ & $<0.60$ & $<0.10$ & $<5.0$ & 146 & $<0.30$ & 320 & 260 \\
\hline U1629 & 4/7/2011 & 1100 & 7.1 & 140 & $<0.006$ & $<0.02$ & $<0.06$ & 0.17 & $<0.5$ & 1,500 & 0.062 & 55 & 450 \\
\hline U1629 & $4 / 7 / 2011$ & 0900 & 3.2 & 120 & $<0.006$ & 0.016 & 0.11 & 0.1 & $<0.5$ & 570 & 0.22 & 20 & 380 \\
\hline U1628 & $7 / 2 / 2009$ & 1000 & E3.5 & 32 & $<0.02$ & $<0.02$ & E0.09 & 0.12 & E0.69 & 17 & E0.04 & 5.2 & 2.0 \\
\hline U1630 & $9 / 15 / 2009$ & 1700 & $<4.0$ & 49 & $<0.02$ & $<0.02$ & $<0.12$ & 0.11 & $<1.0$ & 260 & $<0.06$ & 310 & 81 \\
\hline U1631 & $9 / 16 / 2009$ & 1000 & 400 & 43 & $<0.02$ & 0.02 & $<0.12$ & 0.20 & $<1.0$ & 230 & $<0.06$ & 100 & 600 \\
\hline U1631 & $9 / 16 / 2009$ & 1001 & $<4.0$ & 44 & $<0.02$ & 0.02 & $<0.12$ & 0.19 & $<1.0$ & 230 & $<0.06$ & 101 & 660 \\
\hline U1631 & $12 / 14 / 2009$ & 1630 & $<3.4$ & 43 & $<0.01$ & 0.35 & $<0.12$ & 0.60 & $<1.0$ & 370 & $<0.03$ & 91 & 490 \\
\hline U1647 & $4 / 21 / 2010$ & 1300 & $<34$ & 97 & $<0.12$ & $<0.20$ & $<1.2$ & 2.2 & $<10.0$ & 40 & $<0.30$ & 320 & 300 \\
\hline U7017 & 9/20/2011 & 1200 & $<1.7$ & 240 & 0.009 & $<0.02$ & $<0.06$ & $<0.02$ & $<0.5$ & 1,800 & 0.032 & 120 & 150 \\
\hline U3772 & 9/20/2011 & 1200 & 1.8 & 1,120 & $<0.006$ & $<0.02$ & 0.077 & $<0.02$ & $<0.5$ & 91 & $<0.02$ & 80 & 26 \\
\hline U1645 & $9 / 21 / 2011$ & 1200 & 4.2 & 130 & $<0.006$ & $<0.02$ & 0.19 & 0.03 & $<0.5$ & 630 & $<.01$ & 29 & 150 \\
\hline U1644 & $9 / 21 / 2011$ & 1200 & 6.6 & 480 & 0.008 & $<0.02$ & $<0.06$ & $<0.02$ & $<0.5$ & 94 & $<0.015$ & 730 & 330 \\
\hline
\end{tabular}

${ }^{1}$ Analyzed at the U.S. Geological Survey (USGS) Isotope Laboratory, Menlo Park, Calif.

${ }^{2}$ Analyzed at the USGS Reston Stable Isotope Laboratory, Reston, Va. 
and wells in the Wawarsing study area, and for the Rondout Reservoir at the influent to the Rondout-West Branch Tunnel in Lackawack, Ulster

otherwise noted; --, not measured; NA, not applicable; <, less than; E, estimated value below minimum reporting level; Al, aluminum; Sb, antimony; As, arsenic; Ba, barium; Se, selenium; Ag, silver; Sr, strontium; Tl, thallium; U, uranium; V, vanadium; Zn, zinc; ${ }^{87} \mathrm{Sr} /{ }^{86} \mathrm{Sr}$, stable isotope ratio of strontium- 87 to strontium-86; d, delta; $\delta^{2} \mathrm{H}$, stable isotope ratio of sulfur-34 to sulfur-32 of sulfate relative to the Vienna Canyon Diablo Troilite standard; $\delta^{13} \mathrm{C}$ of DIC, stable isotope ratio of C-13 to C-12 of dissolved inor-

\begin{tabular}{|c|c|c|c|c|c|c|c|c|c|c|c|c|c|c|c|c|}
\hline Mb & $\mathrm{Ni}$ & $\mathbf{A g}$ & Sr & TI & v & $\mathrm{Zn}$ & Sb & As & B & Se & U & $\begin{array}{c}\delta^{2} \mathrm{H} \text { in } \\
\text { water } \\
\text { (per mil) }\end{array}$ & $\begin{array}{c}\delta^{18} 0 \text { in } \\
\text { water } \\
\text { (per mil) }\end{array}$ & $\begin{array}{c}\delta^{34} \mathrm{~S}_{\text {of }} \\
\mathrm{SO}_{4}^{2-} \\
\text { (per mil) }\end{array}$ & $\begin{array}{c}\delta^{13} \mathrm{C} \text { of } \\
\text { DIC } \\
\text { (per mil) }\end{array}$ & $\begin{array}{c}{ }^{87} \mathrm{Sr} r{ }^{86} \mathrm{Sr} \\
(\text { per mil) }\end{array}$ \\
\hline $\mathrm{M}$ & 0.89 & $<0.010$ & 52 & E0.01 & $<0.16$ & E1.4 & E0.03 & 0.13 & 6 & 0.06 & 0.01 & $\begin{array}{l}-52.9 \\
\end{array}$ & -8.44 & 9.36 & -22.1 & 0.71214 \\
\hline 0.3 & 0.48 & $<0.008$ & 160 & $<0.04$ & 0.24 & 3.2 & 0.10 & 0.37 & 15 & 0.40 & 0.76 & -51.3 & -8.15 & -2.95 & -16.6 & 0.71139 \\
\hline 0.2 & 0.34 & M & 130 & $<0.02$ & 0.22 & $<2.8$ & 0.08 & 0.27 & 11 & 0.35 & 0.86 & -71.0 & -10.7 & -3.72 & -16.7 & 0.71136 \\
\hline 6.6 & 0.97 & $<0.01$ & 1,400 & $<0.02$ & 0.35 & E2.2 & 0.27 & 2.5 & 10 & E0.036 & 1.2 & -59.0 & -9.24 & -1.95 & -14.0 & 0.70909 \\
\hline 1.0 & 1.7 & $<0.1$ & 1,220 & $<0.10$ & $<0.80$ & $<14$ & E0.23 & 2.1 & E9 & $<0.20$ & 0.29 & -58.4 & -9.23 & 0.34 & -11.0 & 0.70916 \\
\hline 1.1 & 1.5 & $<0.1$ & 1,200 & $<0.10$ & $<0.80$ & $<14$ & E0.25 & 2.0 & E9 & $<0.20$ & 0.27 & -- & -- & 0.48 & -11.3 & 0.70913 \\
\hline 7.5 & 0.28 & $<0.01$ & 340 & $<0.02$ & $<0.16$ & $<2.8$ & 0.5 & 1.6 & 280 & E0.026 & 0.092 & -61.9 & -9.34 & 8.8 & -14.0 & 0.71164 \\
\hline 0.48 & 0.30 & $<0.005$ & 130 & $<0.01$ & $<0.080$ & 8.3 & $<0.03$ & 5.9 & 6 & $<0.030$ & 0.20 & -55.2 & -8.97 & 0.61 & & 0.7108 \\
\hline 0.68 & 0.26 & $<0.005$ & 120 & $<0.01$ & $<0.080$ & 6.2 & $<0.03$ & 6.4 & 6 & $<0.030$ & 0.30 & -55.7 & -8.97 & -5.08 & & 0.71069 \\
\hline M & 0.33 & $<0.008$ & 35 & $<0.04$ & E0.09 & 2,000 & $<0.04$ & 0.17 & 5 & 0.09 & E0.01 & -56.2 & -8.89 & 2.23 & -- & 0.71227 \\
\hline M & 0.42 & $<0.008$ & 22 & $<0.04$ & $<0.16$ & 5,300 & $<0.04$ & 0.17 & 7 & E0.05 & $<0.01$ & -55.7 & -8.96 & 3.09 & -- & 0.71176 \\
\hline M & 0.64 & $<0.008$ & 23 & $<0.04$ & E0.15 & E2.0 & $<0.04$ & 0.26 & 6 & 0.07 & E0.00 & -54.9 & -8.82 & 3.36 & -- & 0.71196 \\
\hline 0.1 & 0.22 & $<0.008$ & 55 & $<0.04$ & 1.4 & $<2.0$ & E0.02 & 0.37 & E3 & E0.06 & 0.03 & -54.0 & -8.71 & 3.72 & -- & 0.71223 \\
\hline 0.1 & 0.47 & $<0.008$ & 130 & $<0.04$ & E0.10 & $<2.0$ & 0.09 & 0.33 & 19 & 0.3 & 0.46 & -50.4 & -8.01 & -6.84 & -17.7 & 0.71552 \\
\hline 0.2 & 0.38 & $<0.010$ & 150 & $<0.02$ & E0.09 & $<2.8$ & 0.07 & 0.24 & 13 & 0.25 & 0.91 & -68.5 & -10.4 & -6.97 & -15.5 & 0.71148 \\
\hline M & 0.37 & $<0.010$ & 19 & $<0.02$ & E0.09 & $<2.8$ & 0.07 & 0.18 & 9 & 0.06 & E0.01 & -67.9 & -10.5 & 2.79 & -23.5 & 0.71352 \\
\hline-- & -- & -- & -- & -- & -- & -- & -- & -- & -- & -- & -- & -49.0 & -7.95 & -- & -- & -- \\
\hline M & 0.36 & $<0.008$ & 28 & $<0.04$ & 0.26 & 2.0 & E0.02 & 0.53 & 4 & 0.10 & 0.01 & -47.8 & -7.60 & 1.76 & -8.17 & 0.71209 \\
\hline-- & -- & -- & -- & -- & -- & -- & -- & -- & -- & -- & -- & -41.9 & -6.27 & -- & -- & -- \\
\hline 0.5 & 0.77 & $<0.008$ & 120 & $<0.04$ & E0.13 & $<2.0$ & 0.13 & 2.3 & 17 & 0.08 & 0.32 & -40.1 & -5.99 & -3.17 & -- & 0.71125 \\
\hline-- & -- & -- & -- & -- & -- & -- & -- & -- & -- & -- & -- & -40.2 & -6.00 & -- & -- & -- \\
\hline M & 0.52 & $<0.010$ & 44 & $<0.02$ & $<0.16$ & $<2.8$ & E0.03 & 0.21 & 6 & E0.03 & 0.02 & -56.7 & -8.98 & 3.71 & -18.2 & 0.71259 \\
\hline M & 0.43 & $<0.010$ & 47 & $<0.02$ & $<0.16$ & $<2.8$ & 0.06 & 0.34 & 9 & 0.05 & 0.04 & -67.2 & -10.3 & 1.15 & -13.1 & 0.7119 \\
\hline M & 0.34 & $<0.008$ & 16 & $<0.04$ & $<0.16$ & 2.3 & E0.03 & 0.18 & 5 & $<0.06$ & 0.01 & -58.4 & -9.14 & 3.36 & & 0.71416 \\
\hline M & 0.45 & M & 16 & $<0.04$ & $<0.16$ & 5.1 & 0.05 & 0.27 & 4 & E0.05 & 0.02 & -55.3 & -8.76 & 4.16 & -13.8 & 0.71392 \\
\hline-- & -- & -- & -- & -- & -- & -- & -- & -- & -- & -- & -- & -55.9 & -8.77 & -- & -- & -- \\
\hline-- & -- & -- & -- & -- & -- & -- & -- & -- & -- & -- & -- & -56.0 & -8.70 & -- & -- & -- \\
\hline M & 0.48 & $<0.010$ & 19 & $<0.02$ & $<0.16$ & E1.6 & E0.04 & 0.28 & 4 & 0.04 & 0.01 & -55.7 & -8.64 & 4.26 & -13.9 & 0.71419 \\
\hline M & 0.34 & $<0.010$ & 17 & $<0.02$ & $<0.16$ & E2.1 & E0.03 & 0.18 & 4 & E0.03 & 0.02 & -62.7 & -9.58 & 4.16 & -12.9 & 0.71424 \\
\hline 0.5 & 0.37 & $<0.008$ & 150 & $<0.04$ & $<0.16$ & E1.8 & 0.05 & 0.18 & 11 & 0.10 & 0.33 & -57.9 & -9.08 & -8.44 & -12.7 & 0.71416 \\
\hline 1.1 & 3.3 & $<0.010$ & 1,000 & $<0.02$ & E0.11 & 3.7 & 0.12 & 0.25 & 44 & 0.16 & 2.00 & -54.5 & -8.61 & -11.5 & -15.1 & 0.712 \\
\hline 0.52 & 2.3 & $<0.005$ & 90 & $<0.01$ & $<0.08$ & 1.6 & 0.063 & 0.2 & 6.9 & 0.091 & 0.09 & -63.4 & -9.75 & -- & -- & 0.71198 \\
\hline 0.6 & $<0.60$ & $<0.040$ & 590 & $<0.20$ & $<0.80$ & $<10.0$ & $<0.20$ & $<0.30$ & 65 & E0.24 & 0.04 & -56.2 & -8.99 & 0.99 & -13.1 & 0.71158 \\
\hline 1.0 & 8.4 & $<0.005$ & 280 & $<0.01$ & $<0.80$ & 2.1 & $<0.027$ & 0.027 & 22 & $<0.03$ & 0.16 & -55.9 & -8.86 & -- & -- & 0.71129 \\
\hline 1.0 & 4.4 & $<0.005$ & 230 & $<0.01$ & $<0.80$ & 62 & $<0.027$ & 0.057 & 18 & $<0.03$ & 0.22 & -55.9 & -8.86 & -- & -- & 0.71151 \\
\hline 1.1 & 0.81 & $<0.008$ & 380 & $<0.04$ & 1.6 & $<2.0$ & 0.06 & 0.97 & 21 & 0.47 & 0.77 & -61.8 & -9.70 & 25.4 & -9.68 & 0.70983 \\
\hline 2.9 & 0.57 & M & -- & $<0.04$ & $<0.16$ & 2.1 & $<0.04$ & 1.4 & 284 & $<0.06$ & 0.12 & -67.8 & -10.3 & 28.6 & -- & 0.70919 \\
\hline 9.9 & 1.4 & M & 17,700 & $<0.04$ & E0.12 & $<2.0$ & $<0.04$ & 3.9 & 97 & E0.03 & 0.58 & -64.4 & -10.1 & 25.3 & -- & 0.70901 \\
\hline 10.9 & 1.3 & M & 17,800 & $<0.04$ & E0.12 & $<2.0$ & $<0.04$ & 4.0 & 112 & $<0.06$ & 0.64 & -64.6 & -10.0 & 25.3 & -- & 0.70900 \\
\hline 11.8 & 3.9 & M & 19,800 & $<0.02$ & 0.34 & $<2.8$ & $<0.05$ & 6.1 & 92 & $<0.04$ & 0.56 & -64.9 & -9.98 & 25.7 & -12.0 & 0.70902 \\
\hline 3.2 & 2.5 & $<0.1$ & 13,800 & $<0.20$ & 1.9 & $<28.0$ & $<0.54$ & 8.3 & 269 & $<0.40$ & 0.48 & -64.8 & -10.1 & 31.6 & -16.6 & 0.70947 \\
\hline 0.12 & $<0.09$ & $<0.005$ & 180 & $<0.010$ & $<0.080$ & 3.4 & $<0.027$ & 1.2 & 190 & $<0.030$ & 0.006 & -60.8 & -9.52 & -- & -11 & 0.71277 \\
\hline 0.16 & $<0.09$ & $<0.005$ & 580 & $<0.01$ & $<0.080$ & 1.8 & $<0.03$ & 0.67 & 150 & $<0.030$ & 0.03 & -59.0 & -9.26 & -- & -17.3 & 0.71367 \\
\hline 1.5 & 0.33 & $<0.005$ & 850 & $<0.01$ & $<0.080$ & 2.9 & $<0.03$ & 10 & 43 & $<0.030$ & 0.34 & -58.2 & -8.97 & -9.66 & -14.3 & 0.71136 \\
\hline 2.0 & 0.15 & $<0.005$ & 2,170 & $<0.01$ & 0.10 & $<1.4$ & $<0.03$ & 5.3 & 290 & $<0.030$ & 0.11 & -63.8 & -9.77 & -1.88 & -17.5 & 0.71195 \\
\hline
\end{tabular}


THIS PAGE INTENTIONALLY LEFT BLANK 
Prepared by the Pembroke, West Trenton, and Columbus Publishing Service Centers.

For additional information write to: New York Water Science Center

U.S. Geological Survey

2045 Route 112, Bldg. 4

Coram, NY 11727

Information requests:

(518) 285-5602

or visit our Web site at: http://ny.water.usgs.gov 


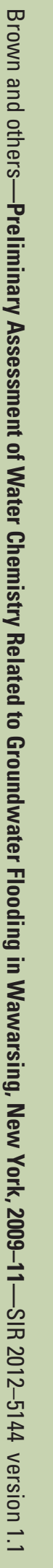

Printed on recycled paper

ISBN 978-1-4113-3504-2 